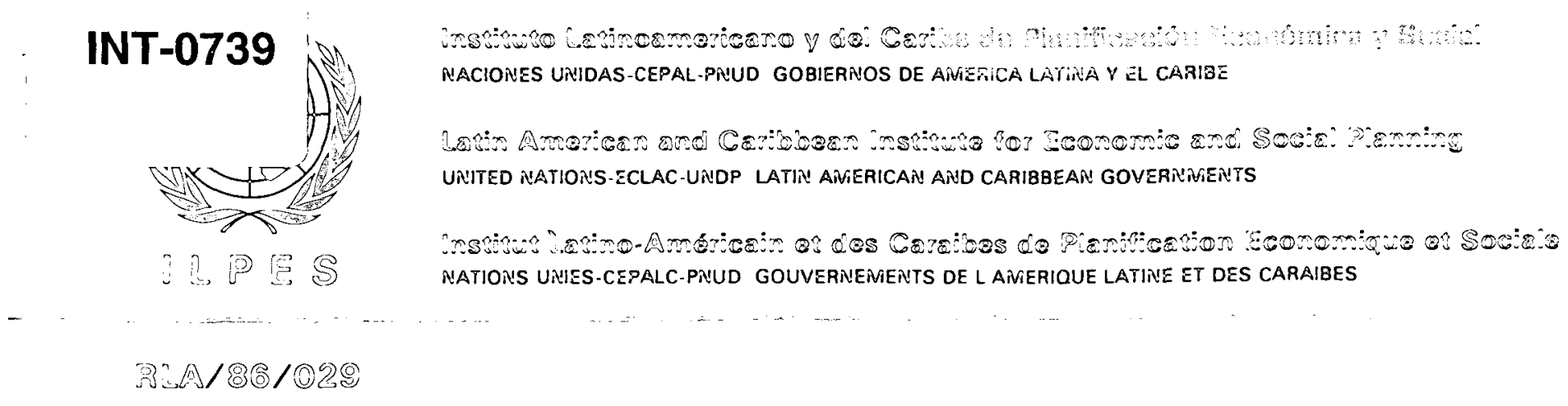

MODELS FOR ANALYZING COMPARATIVE ADVANTAGE

David A. Kendrick

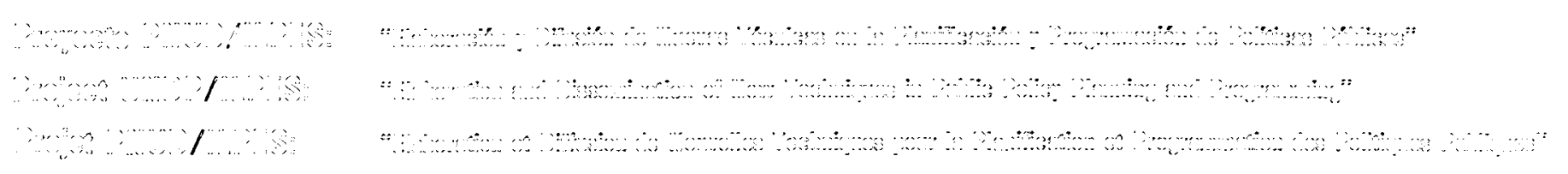

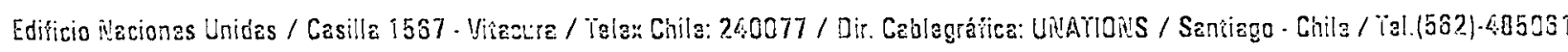




\section{MODELS FOR ANALYZING COMPARATIVE ADVANTAGE}

by

David A. Kendrick

A STUDY SPONSORED BY ILPESIUNDP

KLUWER ACADEMIC PUBLISHERS

DORDRECHT / BOSTON / LANCASTER 


\section{Ubrary of Congress Cataloging In Publication Data}

Kendrick, David Andrew

Model for Analyzing Comparative Advantage / David Andrew Kendrick

v. ?)

Podel for Analyzing Comparative Advantage / David Andrew Kendrick
p. cm. - (Advanced studies in theoretical and applied econometrics :

Includes index.

ISBN $x-x \times x x \cdot x \times x x-x$

1. Internetional Economics. 2. Development Economics.

\section{ISBN $x-x 000 x-x 000 x-x$}

Published by Kluwer Academic Publishers,

P.O. Box 17, 3300 AA Dordrecht, The Netherlands

Kluwer Academic Publishers incorporates

the publishing programmes of

D. Roidel, Martinus Nijhoff, DrW. Junk and MTP Press.

Sold and distributed in the U.S.A. and Canade

by Kluwer Academic Publishers,

101 Phillips Drive, Norwall, MA 02061, U.S.A.

In all other countries, sold and distributed

by Kluwer Academic Publishars Group.

P.O. Box 322, 3300 AH Dondrecht, The Netherlands.

All Rights Rasarved

Q 1889 by Klumer Acedemic Publishers

No part of the material protected by this copyright notice may be reproduced or

utilized in any form or by any maans, electronic or mechanical

including photocopying, reconding or by any information storage and

rotrieval system, without written permission from the copyright owner.

Printed in the Netherlands 
MODELS FOR ANALYZING

COMPARATIVE ADVANTAGE 
ADVARCED STUDIES IN THEORETICAL AND APPLIED ECONOMETRICS YOLUME?

Managing Editors:

J. P. Ancot, Netharlands Economic Institute, Rotierdam. Tha Netherlands

A. J. Hughes Hallet, University of Nowcastle, England

Editorial Board:

F. G. Adams, University of Pennsylvania, USA

P. Balestra, University of Genava, Switzerland

M. G. Dagenais, University of Montreal, Canada

D. Kendrick, University of Texas, Austin, USA

J. Peelinck, Netherlands Economic Institute, Rottardam, The Netharlands

R. S. Pindyck, Sloen School of Managemant, M.I.T., USA

$H$. Theil, University of Florida, Gainsville, USA

W. Welie, Univarsity of Lodz, Poland

For a complete list of volumes in this series see final page of this volume.

\section{Books by David Andrew Kondrick}

Programming Inwestment In the Process Industries

Notes and Problems in Microsconomic Thoory (with Samual Bowles and Poter Dixon)

The Planning of Industrial Programs (with Andy Stoutjesdijle)

Stochastic Control for Economic Models

Ths Planning of Investment Programs in the Steel Industry (with Alexander Meeraus and Jaima Alatorre)

GAMS: A User's Guide (with Anthony Brooke and Alexander Meeraus)

Feedback: A New Framowork for Mecroeconomic Pollcy 


\section{Preface}

Recent economic history suggests that a key element in economic growth and development for many countries has been an aggressive export policy and a complementary import policy. Such policies can be very effective provided that resources are used wisely to encourage exports from industries that can be competitive in the international arena. Also, import protection must be used carefully so that it encourages infant industries instead of providing rents to industries that are not competitive.

Policy makers may use a variety of methods of analysis in planning trade policy. As computing power has grown in recent years increasing attention has been give to economic models as one of the most powerful aids to policy making. These models can be used on the one hand to help in selecting export industries to encourage and infant industries to protect and on the other hand to chart the larger effects of trade policy on the entire economy.

While many models have been developed in recent years there has not been any analysis of the strengths and weaknesses of the various types of models. Therefore, this monograph provides a review and analysis of the models which can be used to analyze dynamic comparative advantage.

The book is designed to be read at three different levels: conceptual, mathematical, and computational. The conceptual material is contained in the body of the chapters and most of the mathemat ical and computational material is included in appendices to these chapters. The conceptual material constitutes a short book of about 100 pages and provides an introduction to the use of models for analyzing comparative advantage.

The reader who is interested in the mathematical level should read the chapters and the mathematical appendices which are provided to several of the chapters. These appendices include a deiailed specification of the models.

The reader who wishes to progress beyond this level should also read the computer inpuis which are provided in appendices. Most of the models in the book are in the Model Library which is distributed with the GAMS modeling system (Brooke, Kendrick, 
vi PREFACE

and Meeraus (1988)). Therefore, the user can obtain access to these models and is encouraged to modify and solve them.

It is my intention to make available a diskette which contains the GAMS input for many of the models which are mentioned in this book but which are not available in the current version of the the GAMS Model Library. Readers who are interested in obtaining such a diskette should write to me.

I have used the computational level in courses which I have tought to senior undergraduates and to graduate students for some years. The opportunity to begin with existing model of some complexity permits the student to quickly by-pass the simple models which are commonly presented in textbooks. My stu. dents seem to enjoy the opportunity to exercise their creativity by modifying an existing model and using the model to analyze a problem that interest them.

This study was sponsored by the Latin American and Caribbean Institute for Economic and Social Planning (ILPES), an ogency associated with the Economic Commission for Latin America and the Caribbean (ECLAC) of the United Nations. Funding was provided by the United Nations Development Program through the Project RLA 86/029, "Elaboration and Dissemination of New Techniques in Public Policy Planning and Programming".

The author is grateful to Hollis Chenery, Eduardo Garcia and Graham Pyatt for comments on the first draft of the study. Eduardo Garcia in his capacity as Director of Economic Programming of ILPES, made useful suggestions at an initial stage of the work.

David Kendrick

Department of Economics

The University of Texas

Austin, Texas 78712 


\section{Contents}

1. Introduction

Part I

Sectoral Models

2. Structure of Models

Static Models

Dynamic Models

App 2A. A Static Sectoral Model

App 2B. A Dynamic Sectoral Madel

19

33

3. Applications

Single Country

Regional 52

Worldwide

Part II

Economy-Wide Models

4. General Equilibrium SAM Style Models

Johansen Style Models $\quad 77$

Comparative Advantage of General Equilibrium Models

App. 4A. SAM Style General Equilibrium Models

App. 4B. A Johansen Style General
Equilibrium Model

App. 4B. A Johansen Style Cen
Equilibrium Model

5. Growth

119

The Kendrick and Taylor Model 120

The Martens and Pindyck Model 131

Exports 139

Wages and Prices $\quad 140$

Income Distribution $\quad 141$ 
Economies of Scale

Technical Change

Conclusions

App. 5A. A Growth Model

Part III

Conclusions

6. Conclusions

Appendices

A. Latin American Models

References

Index 


\section{1}

\section{Introduction}

The rapid growth in computational power in the last three decades has opened new opportunities for economists to develop disaggregated models to analyze dynamic comparative advantage. Thus while only simple rate of return calculations on an export project could be done thirty years ago, now it is possible to develop models of a worldwide industry in order to analyze the intermational competitiveness of a project. In the past one could study the effects of tariff increases on a single industry. Now one can use multisectoral models to trace the effects of tariff reforms through input-output systems to prices, to income distribution, and back to aggregate demand changes. However, these models are new enough that we are still learning about the breadth of their potential application and about their strengths and weaknesses. Therefore this book provides a review of dynamic comparative sdvantage models with an eye to the use of these models for policy analysis.

There are two broad classes of these models: sectoral and economy-wide. As shown in Figure 1.1 the sectoral models may be for a single country, a region, or the whole world. The economy-wide models are either general equilibrium or growth models.

The sectoral models analyze a single sector such as the steel industry or the chemical fertilizer industry. They include multiple plants and markets and the transportation links between them. The sectoral models reach inside the plants to model the capacity of individual productive units and to consider alternative processes for producing goods. They consider economies of scale in investment so that there are tradeofis between transportation costs and investment costs. Some of these models consider the plants and markets in a single country with exports to and imports from other countries, while other models consider a set of countries in a region with trade flows to other regions. Finally, some of the models are worldwide. 
2 INTRODUCTION

Comparative Advantage Models

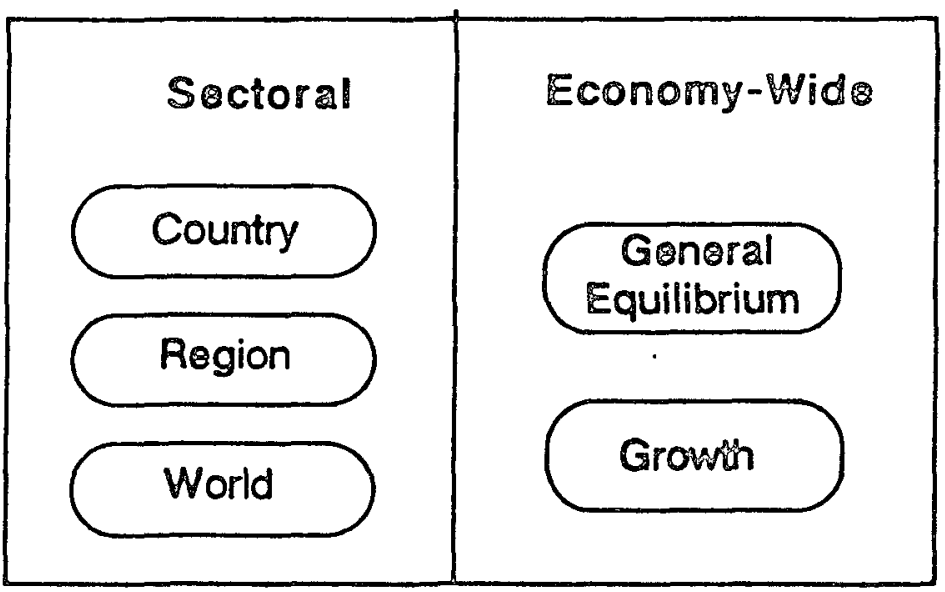

Figure 1.1 Comparative Advantage Models

These sectoral models enable one to analyze the dynamic comparative advantage of a domestic industry while considering the cost of raw materials, labor, and transportation as well as economies of scale in investment. However, these models study only a single industry at a time and fail to consider the larger economy-wide implications of trade policy.

In contrast, the economy-wide models capture the larger picture but lose much of the disaggregated detail. These models can be usefully divided into two groups: general equilibrium and growth models. The general equilibrium models focus on the prices of goods and factors. Therefore these models are useful for analyzing the effects of tariff changes on prices throughout the economy as well on wages and retums to other factors. This means that the models can be helpful in analyzing the income distribution effects of changes in trade policy. For example the ORANI model by Dixon, Parmenter, Sutton, and Vincent (1982) was used to study the effects of tariff reforms in Australia.

Most 'general equilibrium' models include the assumption of perfect competition; however, there is now a group of models in this class that permit substantial price flexibility without the necessity to assume that all sectors are perfectly competitive. Examples of this type of model are those created with the HERCULES software, Drud and Kendrick (1988). This system decreases the time required to develop general equilibrium models 
by providing automatic generation of the equations of the model once the sectors and the function specifications are provided.

Another advantage of the general equilibrium models is that they provide for the specification of price and income elasticities for imports and exports, thus permitting some analysis of comparative advantage in an economy-wide model setting. In contrast, a major disadvantage of the general equilibrium models is that they are usually static. While it is possible to link together a series of general equilibrium models to provide dynamics this is an awkward procedure.

In contrast, the strong suit of the second type of economywide models, the 'growth' models, is dynamics. These model typically consist of a small number of sectors and many time periods. The focus is on capital accumulation and growth. Special attention is given to foreign borrowing and changes in foreign debt. Population growth is also included. Thus these models provide a good overview of comparative advantage at the highly aggregated level while permitting one to study the effects of various foreign borrowing, export stimulation or import restriction policies. The models in this group were originally developed as linear programs and then later as nonlinear programs which permitted facior substitution (see Kendrick and Taylor (1970)).

The economy-wide models provide a consistency framework for national economic policies. This is an important and necessary feature but it also needs to be combined with specifications that permit a country to operate efficiently in the context of the world economy. This means that the models need to focus on the comparative advantage of the country. Moreover the analysis reed to distinguish between those projects which provide privately evaluated and those projects which provide socially evaluated comparative advantage. For example, the price of natural resource like natural gas may be held below world market prices in a country. Then the privately evaluated comparative advantage may suggest combining these resources into a wide range of products for export. In contrast, the socially evaluated comparative advantage would value the resources at world prices and would suggest combining them into a narrower range of products which make more efficient use of the resources in question.

The first part of this monograph describes and analyzes sectoral models and the second part focuses on economy-wide models. 
Part

Sectoral Models 


\section{Structure of Models}

This chapter describes the structure of sectoral models and the following chapter shows how variants of this structure have been used to model a variety of different industries at the country, regional and worldwide level. Static models are discussed first, followed by a description of the more complicated dynamic models.

\section{SEmtic Models}

The essence of sectoral models is that plants and markets are located at different places so that transportation costs must be incurred in shipping goods to markets. Also, the plants are not monoliths with a single production line but rather collections of different productive units of various capacities which perform steps in the production of a variety of intermediate and final goods. The balancing of capacity with demand then depends on the capacity miz at each plant. Since this capacity mix is usually not perfectly balanced, efficiency can be improved by interplant shipments of intermediate products - a phenomenon which is quite important in international trade.

\section{Plants, Markets, and Transportation}

As an example of a secioral model, Fig. 2.1 shows a selection of the plants and markets in the Mexican steel industry. The figure shows the Altos Homos plant in the north of Mexico and the Sicartsa plant on the Pacific coast. In the schema these two plants are shown making shipments to markets in the Mexico City and Guadalajara areas.

The most basic constraints in sectoral models are that no plant can ship more goods than it has the capacity to produce, while each market must receive enough goods from the plants to satisfy 
8 SECTORAL MODELS

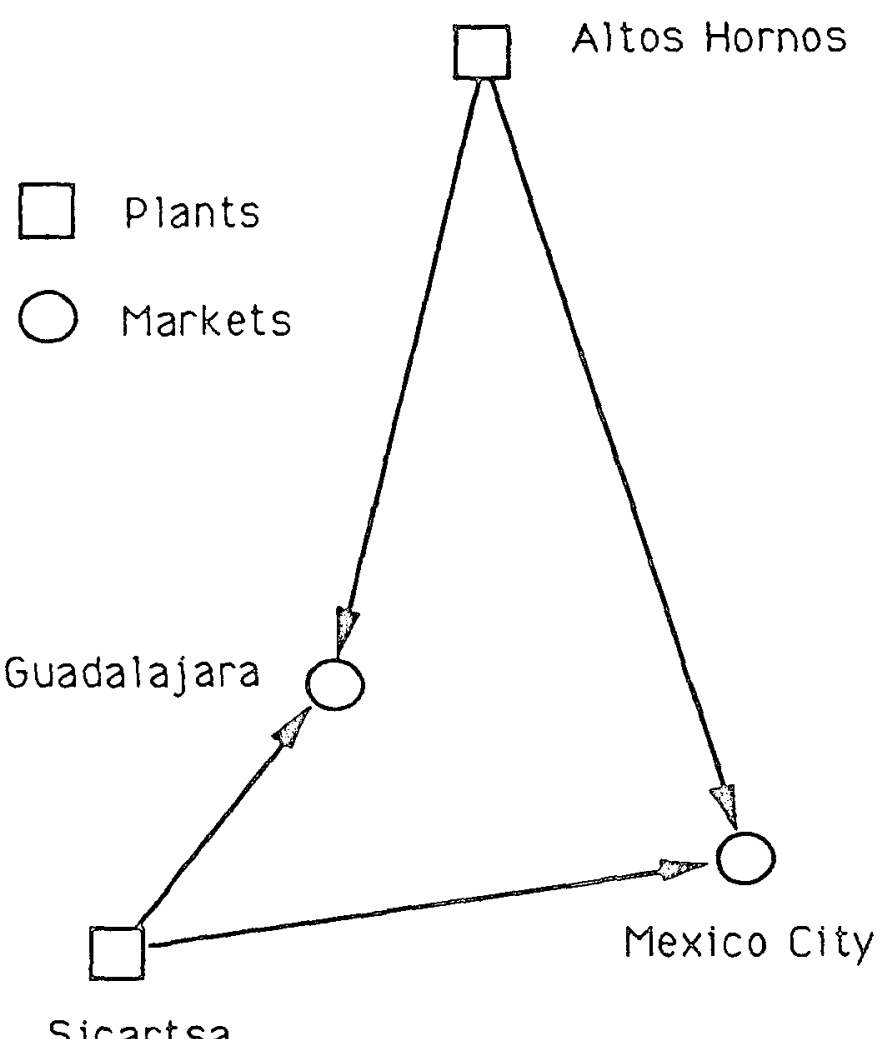

Sicartsa

Figure 2.1 Plants and Markets in the Mexican Steel Industry

its product requirements. These constraints are specified mathe-

matically by first defining the sets of planis and markets, i.e.

$I=$ Plants $=$ (Altos Homos, Sicartsa

$J=$ Markets $=$ \{ Mexico City, Guadalajara

and the capacity at each plant and the demand at cach market as

$$
\begin{aligned}
& \mathbb{k}_{1}=\text { capacity at plant } i \\
& d_{j}=\text { demand at market } j .
\end{aligned}
$$

Also the shipment variables are defined as

$x_{y}=$ shipments from plant $i$ to market $j$

Then the capacity constraint for each plant is written 
(1)

$$
\begin{aligned}
& \sum_{j \in J} x_{v} \leq \quad \mathbb{E}, \quad j \in I \\
& {\left[\begin{array}{c}
\text { shipments to } \\
\text { all mankets } \\
\text { from plant } i
\end{array}\right]\left[\begin{array}{c}
\text { capacity of } \\
\text { plant } i
\end{array}\right]}
\end{aligned}
$$

and the demand constraint for each market is written

(2)

$$
\sum_{l \in I} x_{U} \geq \quad d, \quad j \in J
$$

$$
\left[\begin{array}{l}
\text { shipments to } \\
\text { market } j \\
\text { from all plants }
\end{array}\right] \quad\left[\begin{array}{l}
\text { raguirement } \\
\text { at morket } j
\end{array}\right]
$$

No matter how elaborate sectoral models become, with many products and with plants and markets scattered around the globe, constraints of forms (1) and (2) remain in the models.

The objective function for this simplest version of sectoral models is specified to find the shipment pattern which will minimize transportation cost, i.e.,

(3)

$$
\xi=\sum_{l \in J} \sum_{j \in J} c_{V} s_{V}
$$

where

$\xi=$ total transportation cost

$c_{j}=$ unit transportation cost from plant $i$ to market $j$.

In summary, the simplest form of sectoral models seeks to find the shipment pattem which will minimize transportation cost for final products while satisfying the plant capacity and market requirement constraints. However, since a large portion of the trade flows both within countries and among countries is in the form of intermediate products, it is not sufficient to use only final products in sectoral models. For example a plant's capacity is not defined in terms of a single final product. Rather it is necessary 
10 SECTORAL MODELS

to model the capacity of the various productive units within each plant and to extend the model by using processes to cover not only raw materials but also iniermediate products and final products.

\section{b. Productive Units and Processes}

If we go inside one of the plants, y the steel mill at Sicarisa, we find a number of major productive units as shown in Fig. 2.2.

\section{Sicartsa}

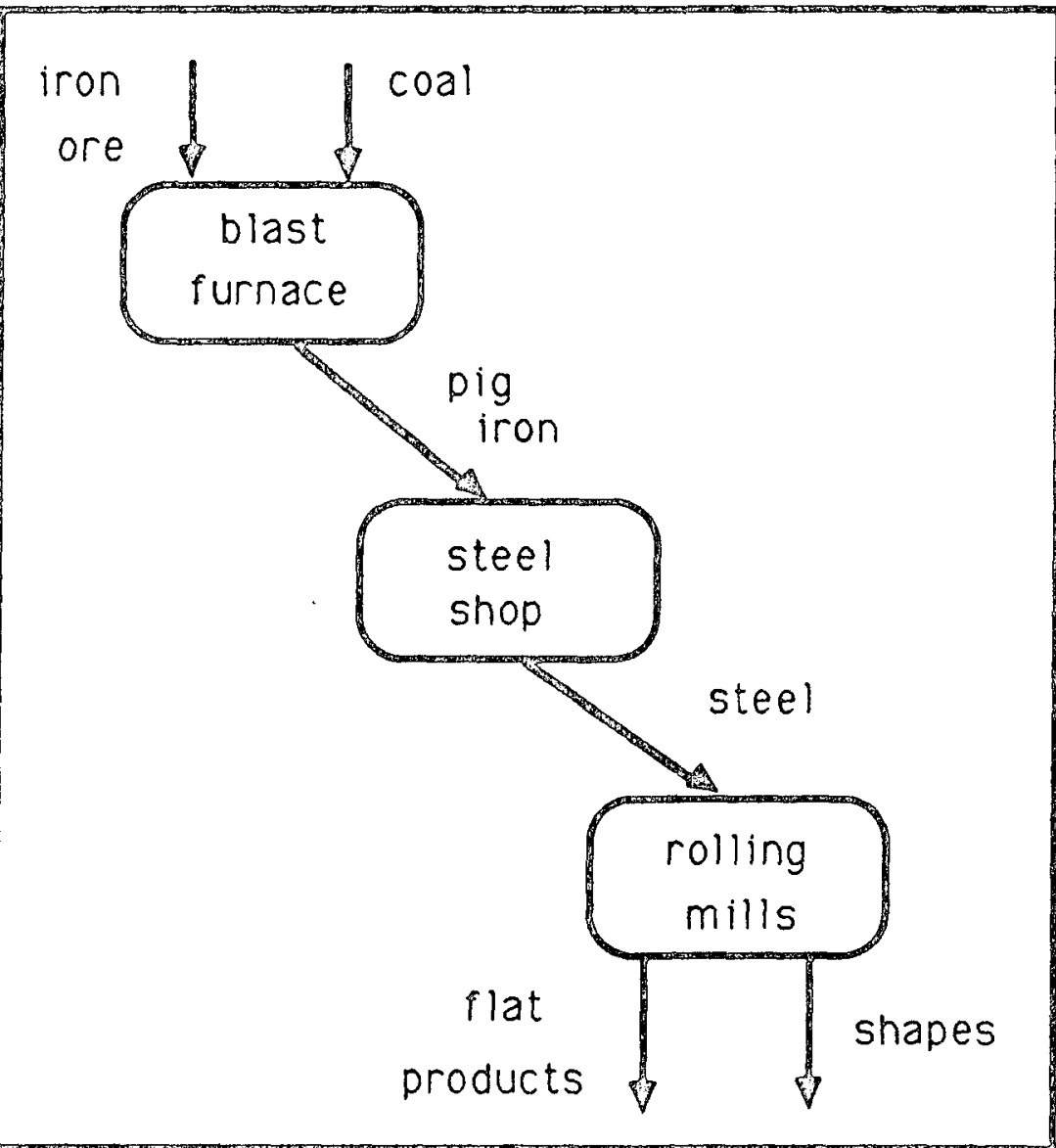

Figure 2.2 Productive Units in the Sicarisa Steel Mill 
In this schema the raw materials, iron ore and coal, are used to make the intermediate product pig iron in the blast fumace. The pig iron is further refined to the intermediate product steel in the steel shop. Finally, the steel is rolled into final products such as nat products which are used for automobile bodies or shapes which are used in Building and bridge construction. With this schema in mind it is necessary to add three material balance constraints to the model, as shown below.

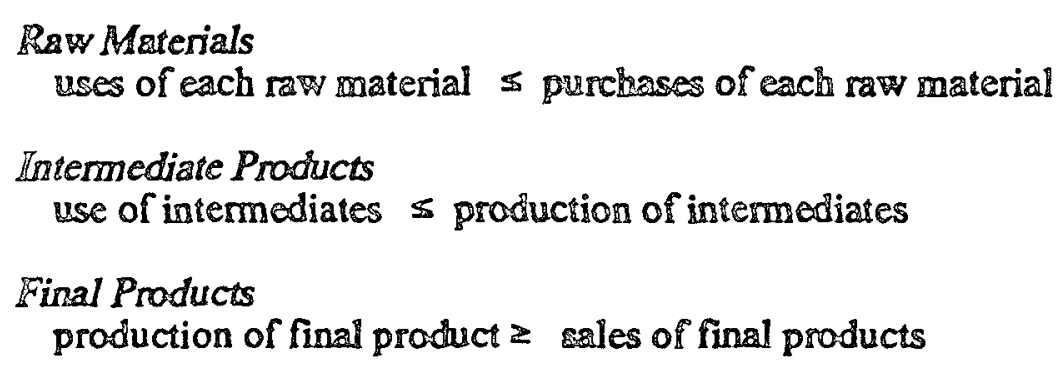

Since such a large portion of international trade is in raw materials and in intermediate products, it is apparent that dynamic models of comparative advantage must disaggregate down to this level.

With the blast furnace, steel shop, and rolling mills in the model as productive units, capacity is now specified not in terms of final products but rather in terms of intermediate products. This opens the door for trade in intermediate products. For esample, if Sicartsa had excess capacity in its steel shop and Altos Homos had excess capacity in its rolling mills, the model solution might indicate a gain in efficiency through shipments of steel ingots from Sicartsa to Altos Homos. Similar shipments are playing a substantial role in the intemational automobile industry, where engines from a plant in one country and rames from a plant in another are combined.

Along with productive units sectoral models use the concept of processes. A process is like a recipe for baking a cake, i.e., it specifies the required amount of each ingredient. A process for making steel is shown in Fig. 2.3. 


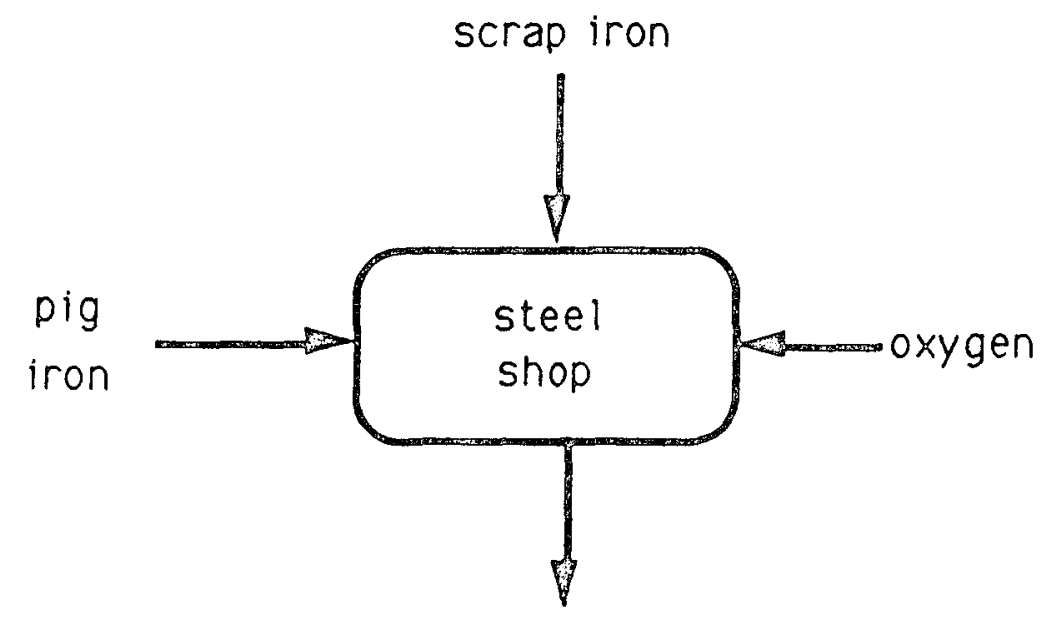

steel

Figure 2.3 Inputs and Ourputs from \& Steel Production Process

Pig iron, scrap iron and oxygen are used in a steel shop to make steel. However, the ratio of these ingredients is not fixed but rather is affected by the relative prices of the three inputs. For example, when scrap iron prices rise steel mills use relatively more pig iron and less scrap iron. Most sectoral models include altemative processes for producing each good. These alternative processes have different ratios of inputs. Then as relative prices change the level of use of the alternative processes also changes, thereby modifying the overall mix of inputs.

In a similar manner, intemational trade in coal and crude oil for use in making electricity is affected by changes in the relative prices of these commodities. Models of the electric power indusiny include altemative processes for producing electricity with coal or with crude oil, and the implied demand for the raw material inputs changes as relative prices change.

\section{c. Exports and Imports}

Exports and imports, like domestic products, must be disaggregated into raw materials, intermediate products and final products. Furthermore, since transportation cost plays an important role, the shipment routes for these products must be included, as shown in the example in Fig. 2.4 for the Mexican steel industry. 


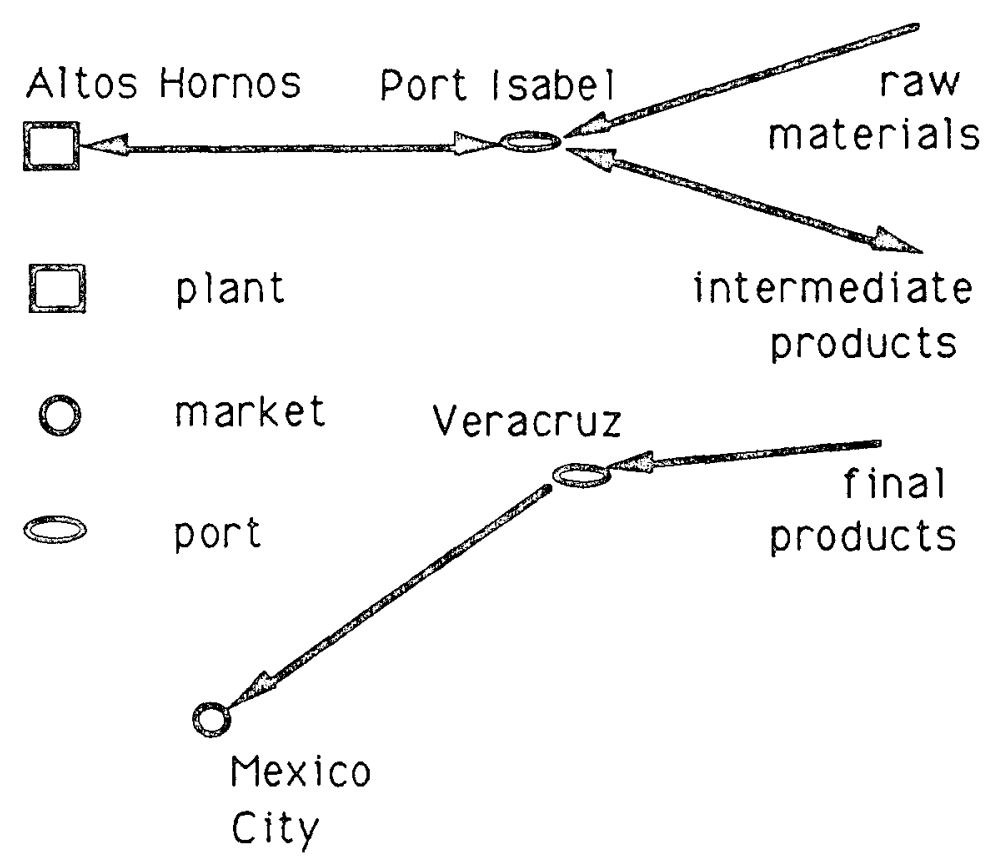

Figure 2.4 Exporis and Imports

Raw material imports enter the country through a port near the plant and intermediate product imports and exports flow through the same port. In contrast, final product imports enter the country through a port near the market. Given the location of plants, marliets and ports, a country may export \& final product through a port near a plant and import the same product from another country through a port near the market.

In sectoral models imports and exports are normally treated as having fixed world prices. It is assumed that the country is small enough not to affect world prices by changes in the volume of its exporis or imports. If this assumption is not correct the models can be modified to include demand functions; however that is not usually necessary.

The treatment of exports and imports in the objective function is a matter of interest. It may be recalled from what was stated above that the goal of the simplest sectoral models is to minimize transportation cost. When processes and productive units are added to the model the goal become the minimization of production and transportation cost. The addition of imports presents no 


\section{IS SECTORAL MODELS}

problem, since this too is an element of cost. However, exports are sources of revenue rather than of cost. Therefore the tradition is to subtract export revenues from the other cost elements and thus to minimize net cost, i.e. transportation, production, and import costs, less export revenues. Thus the objective function for the single country model is to minimize the net cost of satisfying the domestic market requirements.

Some variants of sectoral models include demand function and seel to maximize consumer and producer sumplus. This may be a more appropriate objective function in some cases. This specification is discussed more fully in the section on limitations near the end of this chapter.

Appendix 2 A contains mathematical and computer statements of 2 static sectoral model of the Mesican steel industry. The resder may want to read that appendix before proceeding to the discussion of dynamic models.

\section{Dymsic Models}

The static models discussed above are clearly not suficient to analyze dynamic comparative advantage. One of the key notions of dynamic comparative advantage is that due to economies of scale a country may not have a comparative advantage in a product when its markets are small but may grow into that advantage as the size of the domestic market and the size of production facilities increase. The models discussed in this section include multiple time periods and investment with economies of scale; thus they can be used to analyze dynamic comparative advantage.

\section{Multiple Time Periods}

The first change to be made in the simple models is to add multiple time periods. Thus the shipment variables

$\pi_{y}=$ shipments from plant $i$ to market $j$

bocome

$s_{U_{2}}=$ shipments from plant $i$ to market $\mathrm{j}$ in period $t$. 
Similarly exports, imporis and all other variables gain time subscripts. Also, the constraints become dynamic. For essmple the capacity constraints bocome

capacity utilization 5 inicial capacity + invesment

where the cost of invesiment is subject to economies of scale.

\section{b. Invesiment}

The presence of economies of scale alters the mathematical nature of the sectoral models. If there are diseconomies of scale the optimization problem formed with the sectoral model has a single global optimum. However, if there are economies of scale the optimization problem may have local optima. This means that the model cannot be solved with linear programming methods but instead calls for mired integer programming methods, $c f$. Markowilz and Manne (1957). This in tum means that the computational cost of solving the model is greatly increased.

This computational cost is justified in retum for the capability so answer the question of what size of facility must be built in order to be competitive in intemational markets. Moreover, the model enables one to gauge the effect of the new plant or plants on the existing domestic plants in the industry. In addition, dynamic models also enable one to analyze the phased construction of production capacity. For example, instead of building a small but complete plant waiting a few years and then building another small complete plant, it may be more efficient to build a large but partial plant containing caly the first two stage of production

The products of the first two stages could be exported for a time, then at a later time the final production stage may be added to complete the plant, thus giving the country one large internationally competitive plant rather than two small uncompetitive facilities. Dynamic sectoral models are well suited to analyze this kind of radeofr. A mathematical statement of a dynamic sectoral model is provided in Appendix 2B. 


\section{c. Limitations}

Such are the strengths of sectoral models, but what are the limitations? 1

One major limitation is that most soctoral madels are specified to meet demand requirements at minimum cost. This specification ignores the fact of downward sloping demand functions. Demand functions can be used and the problem converted from one of cost minimization to consumer and producer surplus maximization (cf. Kendrick and Stoutjesdijk (1978) Ch. 7). This changes the optimization problem from a linear to a nonlinear mixed integer programming problem which is more difficult to solve. However, if one is wrilling to approximate the consumer and producer surplus functions with piecewise segments, the problem remains a linear mized integer programming problem.

A second limitation of present sectoral models is the lack of game theory specifications. If there are a few large companies in an industry the construction of new production capacity can be usefully viewed in a game theoretic context. Sectoral models are not usually specified in this way, but they can be used to shed some light on these kinds of problems. The competed model may be used to study the effect on the profitability of one company if another company expands its productive units. Alternatively, in a multicountry model one can study the profitability effects of an expansion in one country on the industry in another country. For example, with world models of the aluminum or copper industries one can study the effects of investment in some countries on profit bility in the rest of the industry.

A third limitation is that the model takes no account of uncertainty, despite the fact there is tremendous uncerainty in the conomy. For example demand projection for ten or twenty years are typically made for sectoral models and then treated with certainty in the model. Likewise, projections are made for future prices of raw materials for a similar time frame.

There are two kinds of uncertainty that can be usefully analyzed in economic models: small event and large event uncertainty. An example of small event uncertainty is month to month variations in demand or in the cost of raw materials. Examples of

1 For related discussion of the limitations of comparative advantage sea Chenery (1961), pp. 277-281. 
lange event uncertainty are the OPEC cartel's effect on oil prices, a war which removes some producers from a world market, or an earthquake which damages some plants. Small event uncertainty can be analyzed effectively in econometric models using stochastic control theory methods, (see Kendrick (1981)). Also it can be done in sectoral models with chance constrained programming, (see Charnes and Cooper (1959)). However, neither of these appraaches is fully satisfactory in sectoral models. In contrast, sectoral models can be used effectively for large event uncertainly by using the models to answer what-if questions. For example, demand might be projected to grow in a particular industry at ten percent over a fifteen year period. An investment plan could be developed under this assumption and then the model solved again under the assumption that there will be no growth in demand in years 5 through 10 of the plan, in order to see the effects on the industry.

Also, most sectoral models would be solved on a rolling-plan basis, whereby the model is solved each year as conditions in the economy evolve and only the first year of the investment strategy is used each year.

A fourth limitation is that factor prices are assumed to reflect opporiunity cost in the economy. However, there are many distortions which affect capital, labor, and resource costs. These distortions must be rocognized and adjustments made in the factor prices if the model results are to reflect comparative advantage.

A fifth limitation stems from the fact that factor prices are not endogenous in sectoral models. The speed of development of a country may affect the rate of growth of wages and therefore the length of time over which it has a comparative advantage in labor intensive commodities. It is possible in sectoral models to have factor prices changing over time in an exogenous fashion; however, this is frequently overlooked.

Dymamic external economies are not captured by the present generation of sectoral models. These economies come from a decreasing cost effect on the inputs of one industry caused by an expansion in the output level of another. For example an increase in automobile production may be great enough for the steel industry to capture increased economies of scale and thus lower the price of the steel they sell to the automobile industry. If international trade in the commodities in question is available this problem may not be too important. If it is important it can be captured in sectoral models by including two or more related industries in the same model. 


\section{SECTORAL MODELS}

Another limitation of sectoral models is the tendency to use current domestic prices, which are sometimes distorted. For example, if the price of a key input is kept below world market prices, then the resource is valued at less than its opportunity cost. This may result in more use of the resource than is socially optimal. The remedy for this problem is to use the world price in the analysis. A related problem is the usse of the current foreign exchange rate in the models despite the fact that that exchange rate may be distorted by government controls. In those cases it is important to make an estimate of the true value of foreign currency and to use that exchange rate in the model.

A final limitation is computational speed. It would seem that with the enormous increases in computer power in recent years sectoral models of great size could now be solved with ease. Some years ago one could build models with about five plants and markets, three productive units, ten commodities (raw materials, intermediate products, and final products), four time periods, and economies of scale in the objective function and solve the model on a mainframe computer using mixed integer programming code. Now one can almost solve a problem of this size on a microcomputer. However, in the modeling of many sectors one wants to use more plants, markets, productive units, commodities, and time periods than those specified above. Therefore computational power continues to be a substantial limitation on the use of sectoral models to analyze dynamic comparative advantage. 


\section{Appendix 2A \\ A Static Sectoral Model}

This appendix contains the mathematical statement and computer input for a static sectoral model which is drawn from Kendrick, Meeraus, and Alatorre (1984) pp. 66-70.

\section{Mathenatical Statement}

Sets

$$
\begin{aligned}
& \text { i } \in I=\text { plants } \\
& j \in J=\text { markets } \\
& m \in M=\text { productive units } \\
& p \in P=\text { processes } \\
& c \in C=\text { commodities } \\
& c \in C F=\text { final products } \\
& c \in C I=\text { intemediate products } \\
& c \in C R=\text { raw materials }
\end{aligned}
$$


20 SECTORAL MODELS

\section{Variables}

$$
\begin{aligned}
& z=\text { process levels (production) } \\
& z=\text { shipments of final products } \\
& e=\text { exports of final products } \\
& y=\text { imports of final products } \\
& u=\text { domestic purchases of raw materials } \\
& \xi=\text { total cost } \\
& \phi=\text { cost groups } \\
& \phi_{\nabla}=\text { raw material cost } \\
& \phi_{\lambda}=\text { transport cost } \\
& \phi_{\pi}=\text { import cost } \\
& \phi_{\theta}=\text { export revenues }
\end{aligned}
$$

Parameters

$$
\begin{aligned}
& a=\text { process inputs }(- \text { ) or outputs }(t) \\
& b=\text { capacity utilization } \\
& d=\text { market requirement } \\
& e^{-}=\text {export bound } \\
& k=\text { initial capacity } \\
& p^{d}=\text { prices of domestic raw materials } \\
& p^{e}=\text { prices of exports of final products } \\
& p^{\gamma}=\text { prices of imports of final products } \\
& \mu^{f}=\text { transport cost of final products } \\
& \mu^{e}=\text { transport cast of exporis } \\
& \mu^{y}=\text { transport cost of imports }
\end{aligned}
$$

\section{Constraints}

The model has three main types of constraints and an objective function. The types of constraints are: 
APP. 2A A STATIC SECTORAL MODEL 21

- materials balance

- copacity

- demand roquirements.

Also, there is sometime a fourth group of miscellaneous constraints. Finally, the objective function may consist of a number of component functions such as raw material cost and transport cost.

The materials balance constraints include constraints for final products, intermediate products, and raw materials. The first of these is shown below.

MATERIALS BALANCE CONSTRAINTS FOR FINAL PRODUCTS

$$
\begin{array}{ll}
\sum_{D \in P} a_{c p} z_{p l} \geq \sum_{j \in J} \pi_{c l}+e_{c l} & c \in C F \\
& i \in I
\end{array}
$$

$\left[\begin{array}{c}\text { Production } \\ \text { of final } \\ \text { products }\end{array}\right] \geq\left[\begin{array}{c}\text { Shipment of final } \\ \text { products to domestic } \\ \text { mantets }\end{array}\right]+\left[\begin{array}{c}\text { Exponts of } \\ \text { final } \\ \text { products }\end{array}\right]$

The constraint requires that domestic production of each final product at each plant must exceed domestic shipments and exports of the product. The $z$ variables are process levels. They are like production levels except that they are a generalization of production with many inputs and many outputs. For example, the primary still at an oil refinery has crude oil inputs and a large number of outputs including low-octane gasoline and kerosene. So the production level of the unit is not specified in terms of any one of the outputs but rather in terms of the crude oil input. Likewise the process (activity) level of the unit would be stated in terms of the crude oil input.

In this context the $a_{c p}$ coefficients in Eq. (1) represent the units of commodity $c$ input to or output from process $p$ per unit sctivity level. By convention the inputs have negative coefficients and the outputs have positive coefficients. Thus in the atmospheric still example the coefficient might have the value -1.0 for crude oil, 0.2 for low-octane gasoline and 0.3 for kerosene.

The second material balance constraint is for intermediate products. It illustrates well the role of the plus and minus 
MATERIALS BALANCE CONSTRAINTS FOR INTERMEDIATE PRODUCTS

$$
\sum_{p \in P} \otimes_{c p} Z_{p I} \geq 0 \quad \begin{array}{cl} 
& c \in C I \\
& j \in I
\end{array}
$$

$$
\left[\begin{array}{c}
\text { Net production } \\
\text { of intemodiate } \\
\text { products }
\end{array}\right]
$$

coefficients. Oil refinery models contain not only an amospheric still process but also a calalytic cracking process. The second process takes the low-octane gasoline from the first process and converts it to high-octane gasoline. In this case low-octane gasoline is an intermediate product and would be included in Eq. (2). In this constraint the coefficient might be 0.2 for the atmospheric still process and -0.15 for the catalytic cracking process. Thus the production of low-octane gasoline by the one process would have to be balanced with the use of low-octane gasoline as an input in the second process.

The last materials balance constraint requires, as is shown below, that the amount of raw materials used in processes (with negative 'a' coefficients) must be balanced by positive amounts of raw material purchases. For example a refinery must buy as much crude oil as it uses in its primary still.

MATERIALS BALANCE CONSTRAINTS FOR RAW MATERIALS

$$
\begin{array}{ll}
\sum_{p \in p} a_{c p} Z_{p l}+u_{d} \geq 0 & c \in C \\
& i \in I
\end{array}
$$

$$
\left[\begin{array}{c}
\text { Raw nazterial } \\
\text { used }
\end{array}\right]+\left[\begin{array}{c}
\text { Raw material } \\
\text { purchased }
\end{array}\right] \geq 0
$$

The next constraint belongs to the second type, namely the capacity constraints. The b coefficient in this constraint is one if a paricular machine is used by a process and zero otherwise. 


\section{CAPACITY CONSTRAINTS}

(4)

$$
\begin{array}{ll}
\sum_{p \in P} b_{m p} \mathcal{Z}_{p l} \leq k_{\mathrm{zdd}} & m \in \mathbb{M} \\
{\left[\begin{array}{l}
\text { Coppacity } \\
\text { requirad }
\end{array}\right] \leq\left[\begin{array}{l}
\text { Cracity } \\
\text { available }
\end{array}\right]} &
\end{array}
$$

For example, there might be two altemative processes which run in the primary still at a refinery. The first process would use weet crude and the second would use sour crude. Together they could not be used to process more than the four hundred thousand barrel capacity of the primary still as represented by the $k$ parameter. So one process might be used to process a hundred thousand barrels of oil and the other process assed to process three hundred thousand barrels of oil.

The third type of constraints are market requirement constraints. This constraint requires that the domestic shipment received plus the imporis received at each market must exceed the market requirernent.

\section{MARKET REQUIRERENTS}
(5) $\quad \sum_{l \in J} x_{c t}+v_{\theta} \geq d$
$c \in \mathbb{C F}$
$j \in J$
$\left[\begin{array}{c}\text { Shipments } \\ \text { from plants } \\ \text { so markets }\end{array}\right]+\left[\begin{array}{c}\text { Imports of final } \\ \text { products } c \text { so } \\ \text { manket } j\end{array}\right] \geq\left[\begin{array}{c}\text { Requinements for } \\ \text { fingl product } c \\ \text { at mantset } j\end{array}\right]$

As was mentioned above most static sectoral models also include some miscellaneous constraints. This model has a single constraint of this type, namely the maximum export constraint which is shown below. 


$$
\sum_{l \in l} e_{c l} \leq e^{-} \quad c \in C F
$$

$$
\left[\begin{array}{c}
\text { Total exports of } \\
\text { commodity } \\
c
\end{array}\right] \leq\left[\begin{array}{c}
\text { Bound on exports } \\
\text { of commodity } c
\end{array}\right]
$$

Constraints of this type may arise when the export marketing organization of an industry is able to place only a certain amount of the product in the export market. Constraints of this type must be ireated with great care in sectoral models. It may be more realistic io replace them with a piecewise function in which the more the industry exports the lower the effective price.

The nonnegativity constraints shown below complete the set of constraints in this model.

\section{NONNEGATIVITY CONSTRAINTS}

(7)

$$
\begin{aligned}
& z_{d t} \geq 0 \\
& x_{d j} \geq 0 \\
& \varepsilon_{d} \geq 0 \\
& v_{d} \geq 0 \\
& u_{d} \geq 0
\end{aligned}
$$

$$
\begin{aligned}
& p \in \mathbb{P}, i \in \mathbb{I} \\
& c \in C F, i \in I, j \in J \\
& c \in C F, i \in I \\
& c \in C F, j \in J \\
& c \in C R, i \in I
\end{aligned}
$$

Objective Function

The objective function for the model is shown below.

(8)

$$
\xi=\phi_{\theta}+\phi_{\lambda}+\phi_{B}-\phi_{B}
$$

$\left[\begin{array}{c}\text { Tosal } \\ \text { cost }\end{array}\right]=\left[\begin{array}{c}\text { Raw mat }- \\ \text { erial cost }\end{array}\right]+\left[\begin{array}{c}\text { Transport } \\ \text { cost }\end{array}\right]+\left[\begin{array}{c}\text { Import } \\ \text { cost }\end{array}\right] \cdot\left[\begin{array}{c}\text { Export } \\ \text { revenue }\end{array}\right]$

As was discussed in the chapter on sectoral models this form of the objective originated in models without imports and exports. In those cases the criterion was simply the minimization of cost. When imports and exporis were added the objective became the 
APP. 2A A STATIC SECTORAL MODEL 25

minimization of cost net of expont revenues. The component functions for the objective function are shown below.

\section{RAW MATERIAL COST}

(9)

$$
\phi_{\nabla}=\sum_{c \in Q R} \sum_{i \in l} p_{c}^{d} u_{d}
$$

$\left[\begin{array}{c}\text { Raw material } \\ \text { cost }\end{array}\right]=\left[\begin{array}{c}\text { Domestic price times } \\ \text { ouantity purchosed } \\ \text { of raw material }\end{array}\right]$

As was discussed in the chapter on sectoral models transportation cost include not only the cost of shipping final products to markets but also the cost of shipping (1) exports to poris and (2) imports to markets from ports.

\section{TRANSPORT COST}

(10)

$$
\phi_{\lambda}=\sum_{\varepsilon \in C F} \sum_{|\in|} \sum_{j \in} \mu_{d j}^{f} x_{d j}
$$

$\left[\begin{array}{c}\text { Transport } \\ \text { cost }\end{array}\right]=\left[\begin{array}{l}\text { Cost of shipping final products } \\ \text { from steel mills to markets }\end{array}\right]$

$$
+\sum_{\epsilon \in C P} \sum_{I \in I} \mu_{l}^{e} e_{d}+\sum_{\epsilon \in C P} \sum_{J \in J} \mu_{J}^{\nabla} \nabla_{\theta}
$$

$+\left[\begin{array}{c}\text { Costof shipping final } \\ \text { products from steel } \\ \text { mills to nearest port }\end{array}\right]+\left[\begin{array}{c}\text { Cost of shipping imported } \\ \text { final products from } \\ \text { ports tomarkets }\end{array}\right]$


26 SECTORAL MODELS

IMPORT COST

(11)

$$
\begin{aligned}
\phi_{\delta} & =\sum_{\epsilon \in C F} \sum_{J \in U} p_{c}^{\nabla} \psi_{\theta} \\
{\left[\begin{array}{c}
\text { Import } \\
\cos t
\end{array}\right] } & =\left[\begin{array}{c}
\text { Cost of final products } \\
\text { imported to martets }
\end{array}\right]
\end{aligned}
$$

EXPORT REVENUES

$$
\begin{gathered}
\phi_{s}=\sum_{c \in C P} \sum_{l \in l} p_{c}^{e} e_{d} \\
{\left[\begin{array}{c}
\text { Export } \\
\text { revenues }
\end{array}\right]=\left[\begin{array}{c}
\text { Price imes guantity } \\
\text { of exports }
\end{array}\right]}
\end{gathered}
$$

The following appendix provides a representation of this model in a form that can be used as an input for a computer.

\section{GAMS Representation}

The computer input form of the static model is for the GAMS modeling system, Brooke, Kendrick, and Meeraus (1988). The first two pages of the input follow the mathematical statement above closely. The last four pages are the data for a particular problem namely the steel indusiry in Mexico.

The GAMS representation in the next pages in similar to the MEXSS model which is included in the Model Library which is distribured with the GAMS system. 
APP. 2A A STATIC SECTORAL MODEL 27

STITLE MEXICO STEEL - SMALL STATIC

- FROM KENDRICK D, MEERAUS A AND ALATORRE J, 1984,

- THE PLANNING OF INVESTMENT PROGRAMS IN THE STEEL

- INDUSTRY, THE JOHNS HOPKINS UNTVERSITY PRESS,

- BALTIMORE AND LONDON.

SETS

I STEEL PLANTS

J MARKETS

M PRODUCTIVE URITS

P PROCESSES

C COMMODITIES

CF FINAL PRODUCTS

CI INTERMEDIATE PRODUCTS

CR RAWMATERLALS

VARIABLES

$\begin{array}{llr}\text { VARIABLES } & \\ Z & \text { PROCESS LEVEL } & \text { (MILL TPY) } \\ X & \text { SHIPMENT OF FINAL PRODUCTS } & \text { (MLL TPY) } \\ E & \text { EXPORTS } & \text { (MLL TPY) } \\ V & \text { IMPORTS } & \text { (MILL TPY) } \\ U & \text { PUR OF DOM MATER } & \text { (MILL UNTS PER YEAR) } \\ \text { XI } & \text { TOTAL COST } & \text { (MILL US\$) } \\ \text { PHIPSI } & \text { RAW MATERIAL COST } & \text { (MLL US\$) } \\ \text { PHIILAM } & \text { TRANSPORT COST } & \text { (MLL US\$) } \\ \text { PHIII } & \text { IMPORT COST } & \text { (MLI US\$) } \\ \text { PHIEPS } & \text { EXPORT REVENUE } & \text { (MILL US\$) }\end{array}$

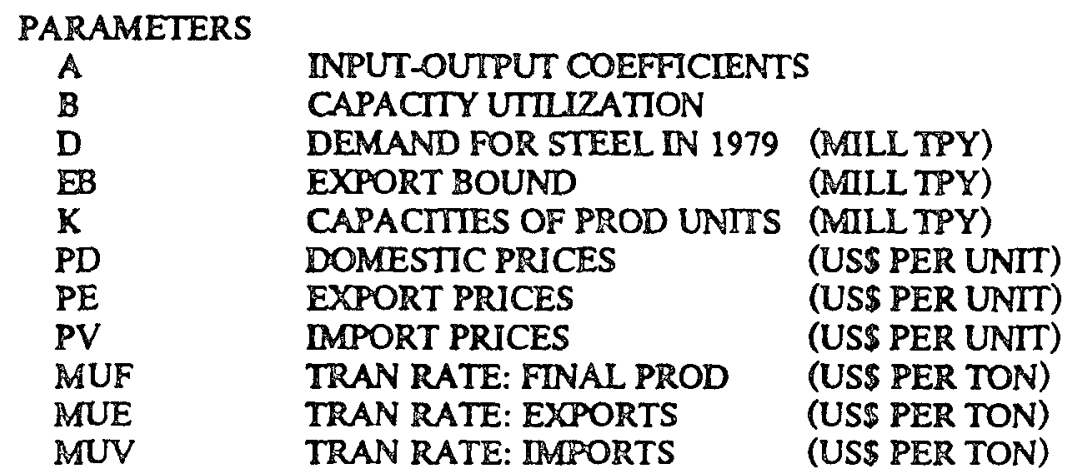


28 SECTORAL MODELS

$\begin{array}{lll}\text { EQUATIONS } & & \\ \text { MBF } & \text { MAT BAL: FINAL PRODUCTS } & \text { (MILL TPY) } \\ \text { MBI } & \text { MAT BAL: INTERMEDIATES } & \text { (MILL TPY) } \\ \text { MBR } & \text { MAT BAL: RAW MATERIALS } & \text { (MLL TPY) } \\ \text { CC } & \text { CAPACITY CONSTRAINT } & \text { (MLL TPY) } \\ \text { MR } & \text { MARKET REQUTREMENTS } & \text { (MILL TPY) } \\ \text { ME } & \text { MAXIMUM EXPORT } & \text { (MLL TPY) } \\ \text { OBI } & \text { ACCOUNTING: TOTAL COST } & \text { (MILL US\$) } \\ \text { APSI } & \text { ACCT: RAW MATERIAL COST } & \text { (MLL US\$) } \\ \text { ALAM } & \text { ACCT: TRANSPORT COST } & \text { (MLL US\$) } \\ \text { API } & \text { ACCT: IMPORT COST } & \text { (MLI US\$) } \\ \text { AEPS } & \text { ACCT: EXPORT COST } & \text { (MLI US\$) }\end{array}$

POSITIVE VARIABLES $Z, X, E, V, U$;

$\operatorname{MBF}(C F, I) . . \quad \operatorname{SUM}\left(P, A(C F, P)^{a} Z(P, I)\right)=G=\operatorname{SUM}(J, X(C F, 1, J))$ $+\mathrm{E}(\mathrm{CF}, \mathrm{I})$;

$\operatorname{MBI}(C I, I) . . \quad \operatorname{SUM}\left(\mathbb{P}, A(C I, P)^{*} Z(P, I)\right)=G=0$;

$\operatorname{MBR}(C R, I) . . \quad \operatorname{SUM}(P, A(C R, P) * Z(P, I))+U(C R, I)=G=0 ;$

$\mathbb{C C}(M, I) . . \quad \operatorname{SUM}\left(P, \mathbb{B}(M, P)^{*} Z(P, I)\right)=\mathbb{L}=K(M, I)$;

$\operatorname{MR}(C F, J) . . \quad \operatorname{SUM}(I, X(C F, \mathbb{J}, J))+V(C F, J)=G=D(C F, J) ;$

$\operatorname{ME}(C F)$.. $\quad \operatorname{SUM}(I, E(C F, I))=L=E B$;

OBJ.. $\quad X I=E-P H I P S I+P H I L A M+P H I P I-P H I E P S$;

APSI.. $\quad$ PHIPSI $=E=\operatorname{SUM}((C R, I), P D(C R) * U(C R, I))$;

ALAM.. PHILAM $=E=\operatorname{SUM}((C F, I, J), M U F(I, J) * X(C F, I, J))$ + SUM((CF,I), MUE(I)*E(CF,I))

+ SUM((CF,J), MUV(J)*V(CF,J));

API.. $\quad P H L P I=E=\operatorname{SUM}\left((C F, J), P V(C F)^{*} V(C F, J)\right)$;

AEPS.. $\quad$ PHILPS $=E=\operatorname{SUM}\left((C F, I), P E(C F)^{*} E(C F, I)\right)$;

MODEL MEXSS SMALL STATIC PROBLEM /ALL/; 
APP. $2 A$ A STATIC SECTORAL MODEL 29

- DATA

SETS

I STEEL PLANTS

I AHMSA

FUNDIDORA

SICARTSA

ALTOS HORNOS - MONCLOVA

HYLSA

MONTERREY

LAZARO CARDENAS

HYLSAP

AONTERREY

I MARKETS

I MEXICO-DF

MONTERREY

GUADALAIA

C COMMODITIES

$/$ PELlETS

COKE

PUEBLA /

NAT-GAS

ELECTRIC

SCRAP

PIG-IRON

SPONGE

STEEL

IRON ORE PELLETS - TONS

TONS

1000 CUBIC METERS

ELECTRICITY - MWH

TONS

MOLTEN PIG IRON - TONS

SPONGE IRON - TONS

TONS

CF(C) FINAL PRODUCTS

/ STEEL /

CI(C) INTERMEDIATE PRODUCTS

/ SPONGE

PIG-IRON/

CR(C) RAW MATERLALS

/ PELLETS

COKE,

NAT-GAS

ELECTRIC

SCRAP /

P PROCESSES

/PIG-IRON

SPONGE STEELOH

PIG IRON FROM PELLETS

SPONGE IRON PRODUCTION

STEEL PROD: OPEN HEARTH 
30 SECTORAL MODELS

STEELEL STEEL PR: ELEC FURNACE

STEELBOF STEEL PRODUCTION: BOF/

M PROD UNTTS

$\begin{array}{ll}/ \text { BLAST-FURN } & \text { BLAST FURNACES } \\ \text { OPENHEARTH } & \text { OPEN HEARTH FURNACES } \\ \text { BOF } & \text { BASIC OXYGEN CONVERT } \\ \text { DIRECT-RED } & \text { DIRECT REDUCTION UNITS } \\ \text { ELEC-ARC } & \text { ELECTRIC ARC FURNACES / }\end{array}$

TABLE A(C,P) INPUT-OUTPUT COEFFICIENTS

PIG-IRON SPONGE STEELOH STEEL-EL STEEL-BOF

\begin{tabular}{|c|c|c|c|c|c|}
\hline PELLETS & -1.58 & -1.38 & & & \\
\hline COKE & -.63 & & & & \\
\hline NAT-GAS & & -.57 & & 50 & \\
\hline $\begin{array}{l}\text { SLEC AP } \\
\text { SCRP }\end{array}$ & & & -.33 & & -.12 \\
\hline PIG-IRON & 1.00 & & -.77 & & -.95 \\
\hline SPONGE & & 1.00 & & -1.09 & \\
\hline STEEL & & & 1.00 & 1.00 & 1.00 \\
\hline
\end{tabular}

TABLE B(M,P) CAPACTYY UTILIZATION

PIG-IRON SPONGE STEEL-OH STEEL-EL STEEL-BOF

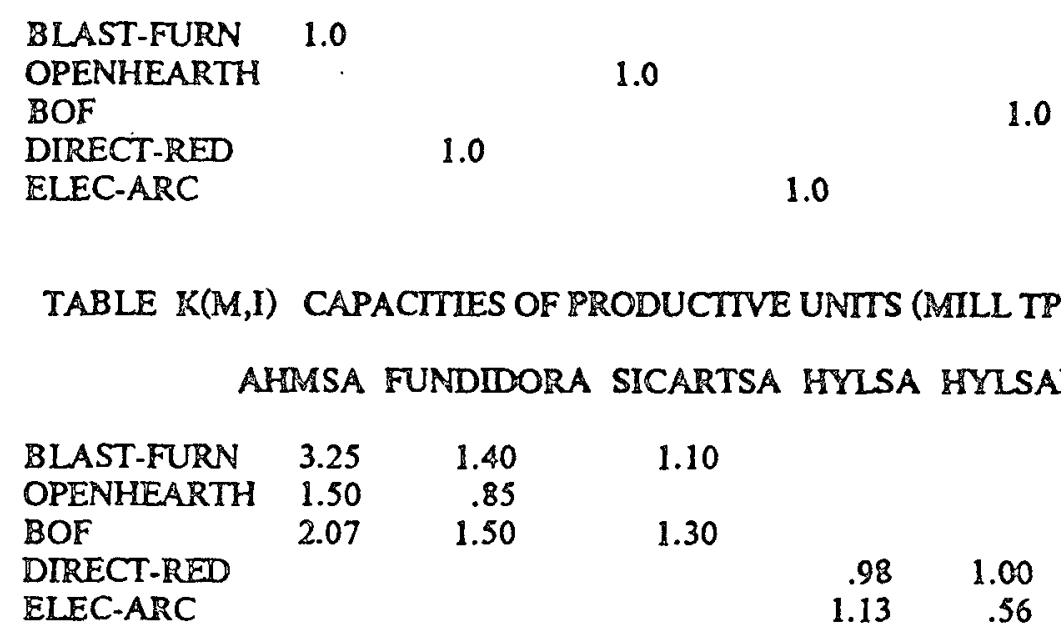


APP. $2 A$ A STATIC SECTORAL MODEL 31

- MARKET DEMAND COMPUTATION

SCALARS DT DEMAND:FINAL GOODS:1979 (MIL TONS)/5.209/ RSE RAW STEEL EQUTVALENCE (PERCENT) / $40 /$

PARAMETERS

DD(J) DISTRIBUTION OF DEMAND

$\begin{array}{cc}\text { / MEXICO-DF } & 55 \\ \text { MONTERRE } & 30 \\ \text { GUADALAJA } & 15 \%\end{array}$

$D($ "STEEL",J) $=\mathbb{D T} *(1+\operatorname{RSE} / 100) * \mathrm{DD}(\mathrm{J}) / 100 ;$

- transportation cost

TABLE RD $\left.{ }^{*}, *\right)$ RAIL DIST FROM PLANTS TO MARKETS (KM) MEXICO-DF MONTERREY GUADALAJA EXPORT

$\begin{array}{lrrrr}\text { AHMSA } & 1204 & 218 & 1125 & 739 \\ \text { FUNDIDORA } & 1017 & & 1030 & 521 \\ \text { SICARTSA } & 819 & 1305 & 704 & \\ \text { HYISA } & 1017 & & 1030 & 521 \\ \text { MYLSAP } & 185 & 1085 & 760 & 315 \\ \text { IMPORT } & 428 & 521 & 300 & \end{array}$

- UNTT TRANSPORTATION COST

$M U F(1, J)=\left(2.48+.008 A^{*} \operatorname{RD}\left(I_{1} J\right)\right) \quad S R D(I, J)$

MUV(J) $=\left(2.48+.0084^{*} R D\right.$ "TMPORT"J)) \$RD("IMPORT"J);

MUE(I) "x $\left(2.48+.0084^{*}\right.$ RD (I, "EXTPORT")) \$RD(I,"EXPORT");

PRICES

TABLE PRICES(C, PRODUCT PRCES (US\$ PER UNTT)

DOMESTIC IMAPORT EXOPORT

$\begin{array}{lr}\text { PELLETS } & 18.7 \\ \text { COKE } & 52.17 \\ \text { NAT-GAS } & 14.0 \\ \text { ELECTRIC } & 24.0 \\ \text { SCRAP } & 105.0 \\ \text { STEEL } & \end{array}$

STEEL

150. 140. 
32 SECTORAL MODELS

- DOMESTIC, IMPORT, AND EXIPORT PRICES

$P D(C)=\operatorname{PRICES}\left(C,{ }^{\prime D O M E S T I C}\right)$;

PV(C) = PRICES(C, "TMPORT");

PE(C) $\approx$ PRICES(C, "EXPORT"

- EXPORT BOUND

$E B=1.0$;

- SOLVE STATEMENT

SOLVE MEXSS USING LP MINIMIZZTNG XI;

* DISPLAY RESULTS

DISPLAY Z.L, X.L, U.L, V.L, E.L ; 


\section{Appendix 2B \\ A Dynamic Sectoral Model}

This appendix contains the mathematical statement of a dynamic sectoral model which is drawn from Kendrick, Meeraus, and Alatorre (1984) pp. 230-236. The model here is simplified somewhat for ease of exposition by eliminating mines from the previous model.

Sets

$$
\begin{aligned}
& i \in I=\text { plants } \\
& j \in J=\text { markets } \\
& \text { m } \in M=\text { productive units } \\
& p \in P=\text { processes } \\
& c \in C=\text { commodities } \\
& c \in C R=\text { raw materials } \\
& c \in C V=\text { imported raw materials } \\
& c \in C I=\text { interplant shipments } \\
& c \in C F=\text { final products } \\
& c \in C E=\text { exportable commodities } \\
& t \in T=\text { time periods } \\
& B \in G=\text { grid points }
\end{aligned}
$$

Variables

$$
\begin{aligned}
& z=\text { process levels (production) } \\
& x^{f}=\text { shipments of final products } \\
& x^{n}=\text { interplant shipments } \\
& e=\text { exports of final products } \\
& v^{f}=\text { impons of final products } \\
& v^{r}=\text { imports of materials to plants }
\end{aligned}
$$


34 SECTORAL MODELS

$$
\begin{aligned}
& u=\text { domestic purchoses of raw materials } \\
& h=\text { investment variables } \\
& s=\text { convex combination variables } \\
& y \text { a zero - one variables } \\
& \xi=\text { total cost } \\
& \phi_{\pi}=\text { invesiment } \cos \psi \\
& \phi_{\nabla}=\text { rav meterial cost } \\
& \phi_{\lambda}=\text { transport cost } \\
& \phi_{\lambda}=\text { import cost } \\
& \phi_{\sigma}=\text { expor revenues }
\end{aligned}
$$

Parameters

$$
\begin{aligned}
& a \text { a process inputs ( - )or outputs }(t) \\
& b=\text { capacity utilization }
\end{aligned}
$$

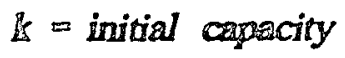

$$
\begin{aligned}
& d=\text { market raguirement } \\
& e^{\prime \prime}=\text { export bound } \\
& 5^{-}=\text {grid points for invesment function } \\
& p^{d}=\text { prices of domestic raw materials } \\
& p \text { a prices of imports of final products } \\
& p^{e}=\text { prices of exports of final prosucts } \\
& \delta=\text { discount fector } \\
& \mu^{f}=\text { transport cost of final products } \\
& \mu^{e}=\text { transport cost of exports } \\
& \mu^{m}=\text { transpont cast for interplant shipments } \\
& \mu^{\prime}=\text { transport cost of imports } \\
& \theta=\text { years per time period } \\
& \sigma \text { a capioal recovery factor } \\
& \bar{\omega}=\text { investment cost grid points }
\end{aligned}
$$


APP. 28 A DYNAAIC SECTORAL MODEL 35

\section{Constrainis}

The model has three main types of constraints and an objective function. The types of constraints are:

- materials balance

- capacity and investment

- demand requirements

Also, there is sometime a fourth group of miscellaneous constraints. Finally, the objective function may consist of a number of component functions such as investment cost and transport cost.

There were three materials balance constraints in the static model. However, as the number of different types of commodities increases it is more efficient to use a single commodity constraint and to restrict the set of commodities over which the various variables are created. For example the raw material purchases variable which is shown below has a $c$ subscript and the $c \in C$ notation on the right would indicate that there is a variable

$$
u_{c A_{k \in C R}} \quad c \in C
$$

of this type for all commodities. However the $\mid c \in C R$ notation with the bar under the u variable indicates that this variable should be created only for the commodities which are raw materials. 


\section{MATERIALS BALANCE CONSTRAINTS}

(1)
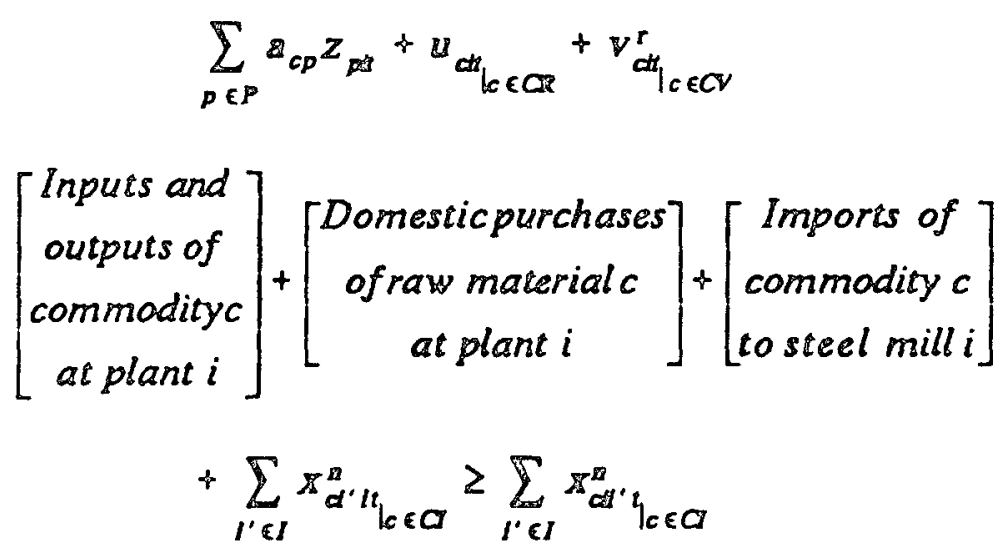

The constraint requires that net production plus purchases plus imports plus incoming interplant shipments must exceed outgoing interplant shipment plus final product shipments plus exports.

The next constraints belongs to the second type, namely the capacity and investment constraints. 


\section{CAPACITY CONSTRAINTS}

(2)

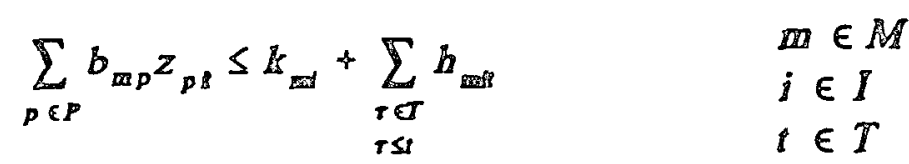

$$
\left[\begin{array}{l}
\text { Capacity } \\
\text { utilized }
\end{array}\right] \leq\left[\begin{array}{c}
\text { Initial } \\
\text { caspacity }
\end{array}\right]+\left[\begin{array}{c}
\text { Capacity added } \\
\text { before or during } \\
\text { aime period } t
\end{array}\right]
$$

The capaciry constraint is the same as in the static model except that the initial capacity can be increased by investments made in each time period.

The $b$ variable is the addition to capacity for a particular production unit, plant, and time period. Therefore the right hand side of the constraint above includes a summation over all previous time periods. Moreover, as is shown below the h variable is the convex combination $a$ of set of grid points. This formulation permits the investment cost function to contain both economies of scale and diseconomies of scale in different domains of the function, cf. Kendrick, Meeraus, and Alatorre (1984) pp. 213-7. For example a blast fumace may have an investment function with economies of scale in the domain up to 5 million tons per year and diseconomies of scale thereafter.

DEFINITION OF $b$

$$
\begin{aligned}
& h=\sum_{s \in O} h_{E S}^{-} s_{m g h} \\
& \text { m } \in M \\
& i \in I \\
& t \in T
\end{aligned}
$$

$$
\left[\begin{array}{c}
\text { Addition to capacity } \\
\text { in productive unit } \mathrm{um} \\
\text { period } t
\end{array}\right]=\left[\begin{array}{c}
\text { Convex combination } \\
\text { of investment sizes } h \\
\text { mill in point } g \text { for } \\
\text { productive unit } \mathrm{m}
\end{array}\right]
$$

The summation of the $s$ variables are further constrained to equal either one or zero by Eq. 4. If the $y$ variable takes on the value of one then there will be investment in a particular production 
function, plant, and time period; otherwise there will be no investment for that particular combination. This constraint is necessary because of the presence of economies of scale.

\section{CONVEX COMBINATION CONSTRANTS}

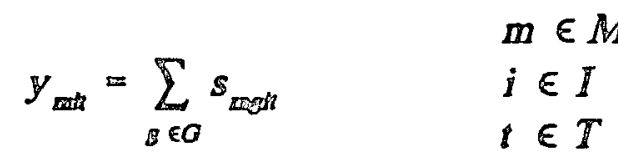

$\left[\begin{array}{c}\text { zero or one } \\ \text { investment } \\ \text { choice } \\ \text { varisble }\end{array}\right]=\left[\begin{array}{c}\text { Conver combination } \\ \text { variables must sum } \\ \text { to zero or one }\end{array}\right]$

The third type of constraint is the market requirement constraint shown below. This constraint requires that for each inal product the domestic shipments received plus the imports received at each market must exceed the raciuirement in each time period.

MARKET REQUTREMENTS

$$
\begin{array}{ll} 
& c \in C F \\
\sum_{i \in i} x_{d y}+v_{\alpha s}^{f} \geq d_{d s} & j \in J \\
& t \in T
\end{array}
$$

$\left[\begin{array}{c}\text { Shipments } \\ \text { from plants } \\ \text { to mankets }\end{array}\right]+\left[\begin{array}{c}\text { Lmports of final } \\ \text { products } c \text { so } \\ \text { manket } j\end{array}\right] \geq\left[\begin{array}{c}\text { Requirements for } \\ \text { final product } c \\ j \text { market } j\end{array}\right]$

As was mentioned above most static sectoral models also include some miscellaneous constraints. This model has a single constraint of this type, ramely the maximum export constraint which is shown below. 
EYPORT UPPER BOUND

(6)

$$
\begin{gathered}
\sum_{c \in C B} \sum_{i \in t} e_{c t} \leq e_{t}^{u} \\
{\left[\begin{array}{c}
\text { Toisl exports } \\
\text { in period } t
\end{array}\right] \leq\left[\begin{array}{c}
\text { Export upper } \\
\text { bound }
\end{array}\right]}
\end{gathered}
$$

This constrain differs from the similar constraint in the static model in that is permits different export bound in each time period.

The nonnegativity constraints and the binary variable constraint shown below complete the set of constraints in this model.

NONNEGATTVTYY CONSTRAINTS

$$
\begin{aligned}
& z_{\text {pit }} \geq 0 \quad p \in \mathbb{P}, i \in I, t \in T \\
& \pi_{\text {cup }}^{f} \geq 0 \quad c \in \mathbb{C} F, i \in I, j \in J, \hat{i} \in \mathbb{I} \\
& x_{d^{\prime} l s}^{n} \geq 0 \quad c \in C I, i^{\prime} \in I, j \in I, t \in T \\
& \& \geq 0 \quad c \in C R, i \in I, t \in I \\
& \mathbb{W}^{f} \geq 0 \quad c \in C F j \in J, t \in T \\
& \nabla_{c t t}^{r} \geq 0 \quad c \in C V, i \in I, t \in T \\
& e_{a t} \geq 0 \quad c \in C E, i \in I, t \in T \\
& b_{m} \geq 0 \quad Z A \in M, i \in I, i \in T \\
& s_{\text {math }} \geq 0 \quad \text { In } \in M g \in G, j \in I, t \in T
\end{aligned}
$$

BINARY VARIABLE

(8)

$$
\begin{aligned}
& y=0 \text { or } 1 \quad i \in I \\
& t \in T
\end{aligned}
$$

\section{Objective Function}

The objective function for the model is shown below. 


$$
\xi=\sum_{t \in T} \delta_{t} \theta
$$

$$
\left[\begin{array}{c}
\text { Total } \\
\text { cost }
\end{array}\right]=\left[\begin{array}{c}
\text { Discount } \\
\text { fector }
\end{array}\right]\left[\begin{array}{c}
\text { Years per } \\
\text { time period }
\end{array}\right]
$$

$$
\left(\phi_{x t}+\phi_{\nabla t}+\phi_{\lambda t}+\phi_{z t}-\phi_{a}\right)
$$

$\left[\begin{array}{c}\text { Invest } \\ \text { ment } \\ \text { cost }\end{array}\right]+\left[\begin{array}{c}\text { Raw } \\ \text { material } \\ \text { cost }\end{array}\right]+\left[\begin{array}{c}\text { Transport } \\ \text { cost }\end{array}\right]+\left[\begin{array}{c}\text { Import } \\ \text { cost }\end{array}\right]-\left[\begin{array}{c}\text { Export } \\ \text { revenue }\end{array}\right]$

This function differs from the static model function in two ways:

(1) there is discounting of the cost with the $\delta_{t}$ parameter and (2) there is multiplication of the annual cost by the parameter $\theta$ which is the number of years per time period. The last parameter is necessary becouse the models usually include three or four time period with each time period having three to five years. This is necessary because the model becomes too large if it includes 15 to 20 annual time periods.

The component functions for the objective function are shown below. The first of these, the investment cost function, is new.

\section{INVESTMENT COST}

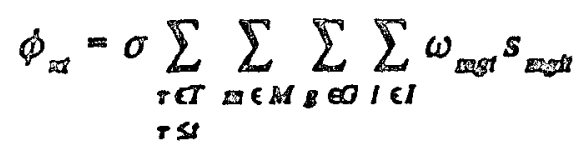$$
t \in T
$$

The $s$ variables play the same convex combination role that they played with the 5 grid point variables above, except that now the grid points are the corresponding cost $\omega$. The investment cost function is made up of a series of linear segments and at each break in the function there is a grid point.

The $\sigma$ in Eq. 10 plays a different role. It converts capital cost to rental payments. The reason for this is that if the entire capital cost of an investment is included in the cost function very little investment will occur. If on the other hand the investment portion 
APP. $2 B$ A DYNAMIC SECTORAL MODEL 41

of the cost function is treated like rental payments on capital goods then there is a balance in time between the benefits which accrue from investment and the payment of the cost. The parameter $\sigma$ may have a value like ten percent indicating that ien percent of the cost the capital cost is paid as rental cost in each year.

Care should be exercised in the use of this function since one can effectively go on paying for a piece of equipment after the equipment is retired. This has not been a problem in most applications since the models cover relatively short periods of time, but it could be if models are built to cover longer periods of time.

The raw material cost function shown below is the same as the equivalent function in the static models except for the addition of the time period subscripts.

RAW RATERIAL COST

$$
\phi_{v t}=\sum_{c \in C R} \sum_{t \in I} p_{c t}^{d u} \quad t \in T
$$

$$
\left[\begin{array}{c}
\text { Row material } \\
\text { cost }
\end{array}\right]=\left[\begin{array}{c}
\text { Domestic price times } \\
\text { guantity purchased } \\
\text { of row material }
\end{array}\right]
$$

The transportation cost function below differs from the static model function by the inclusion of two additional terms: (1) interplant shipment cost and (2) transportation cost for imports of raw materials and intermediate products to plants. 
42 SECTORAL MODELS

TRANSPORT COST

(12)

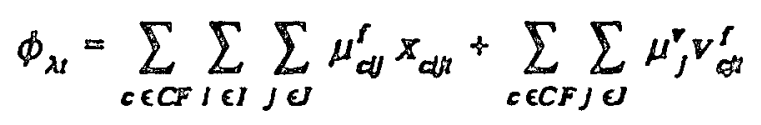

$\left[\begin{array}{c}\text { Traasport } \\ \text { cost }\end{array}\right]=\left[\begin{array}{c}\text { Final products } \\ \text { no markets }\end{array}\right]+\left[\begin{array}{c}\text { Imports } \\ 10 \text { morkets }\end{array}\right]$

$+\sum_{c \in C F} \sum_{I \in I} \mu_{i}^{e} e_{c t}+\sum_{c \in C} \sum_{I \in I} \sum_{l \cdot U l} \mu_{\|}^{n}, x_{e s t}^{n}+\sum_{c \in C V} \sum_{I \in I} \mu_{i}^{e} V_{c t}^{r} t \in T$

$$
+[\text { Esports }]+\left[\begin{array}{l}
\text { Interplant } \\
\text { shipments }
\end{array}\right]+\left[\begin{array}{c}
\text { Imsports } \\
\text { to plants }
\end{array}\right]
$$

The import cost function includes one additional terms which was not in the equivalent static model function namely the cost of materials imported to plants.

\section{IMPORT COST}

$$
\begin{aligned}
& \phi_{s t}=\sum_{c \in C F} \sum_{j \in J} p_{c}^{r} V_{c t}^{f}+\sum_{c \in C V} \sum_{I \in I} p_{c}^{y} V_{c t}^{r} \\
& {\left[\begin{array}{c}
\text { Import } \\
\text { cost }
\end{array}\right]=\left[\begin{array}{c}
\text { Imports } \\
\text { to manlsets }
\end{array}\right]+\left[\begin{array}{c}
\text { Imports } \\
10 \text { plants }
\end{array}\right]}
\end{aligned}
$$

The export revenue function is the same as the function for the static model with the exception of the addition of the time period subscripts.

EXPORT REVENUES
(14) $\phi_{E t}=\sum_{c \in C E} \sum_{l \in I} p_{c}^{e} e_{c H}$
$t \in T$
$\left[\begin{array}{c}\text { Export } \\ \text { revenues }\end{array}\right]=\left[\begin{array}{c}\text { Price times quantity } \\ \text { of exports }\end{array}\right]$ 


\section{3 \\ Applications}

One of the most effective means of understanding the scope of sectoral models as well as their strengths and weaknesses is to review the results of previous applications of this methodology. This chapter begins with single country madels and progresses to regional and then worldwide models.

\section{Single Country}

Single country models have been developed for a number of industries including steel, fertilizers petrochemicals, pulp and paper, electric power, and cement. These industries are all process industries in the sense that raw materials are transformed in a fairly continuous set of processes into final products.

This review of sectoral models is not intended to be comprehensive, but rather illustrative. Thus in each case a model or models are selected which indicate the scope of applications and the comparative strengths and weaknesses of the methodology.

\section{Steel}

The Mexican steel industry was the subject of a substantial study by the World Bank in 1979 (Kendrick, Meeraus and Alatorre (1984)). At that time there were five principal steel mills and three large market areas as is shown in Figure 3.1. Supply and demand were fairly evenly balanced at around 8 million tons per year so there was not a large quantity of either exports or imports. 
APP. 28 A DYNAMIC SECTORAL MODEL 43

In summary the dynamic model seeks to find production, shipment, export, import, and investment variables to minimize the net cost of meeting the market constraints over time. The model permits economies of scale in invesiment cost and is therefore useful for analyzing dynamic comparative advantage.

This model is included in the Model Library which is distributed with the GAMS System. It is labelled, Mexican Steel Small Dynamic, MEXSD. 


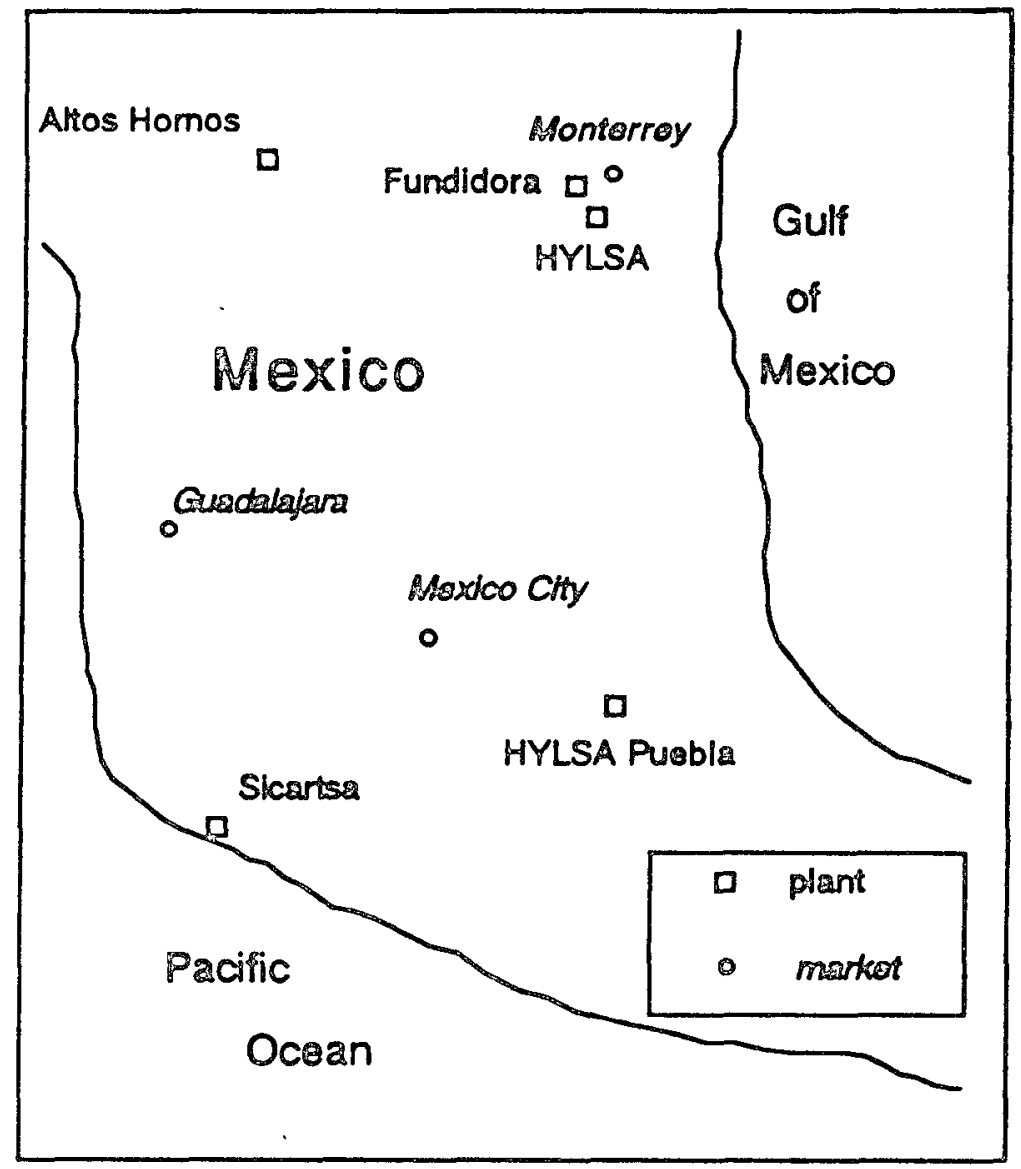

Figure 3.1 The Mexican Steel Industry

There were two kinds of technology in use for producing steel and the economics of these two technologies were decidedly different. The conventional technology is shown in Fig. 3.2. This technology uses iron ore and coal inputs to a blast furnace which produces pig iron. Scrap iron is added to the pig iron in the BOF (basic oxygen furnace) and the metal is refined to steel. There are strong economies of scale in the blast furnace and moderate economies of scale in the basic oxygen furmace. This technology was in use in three of the five plants. 


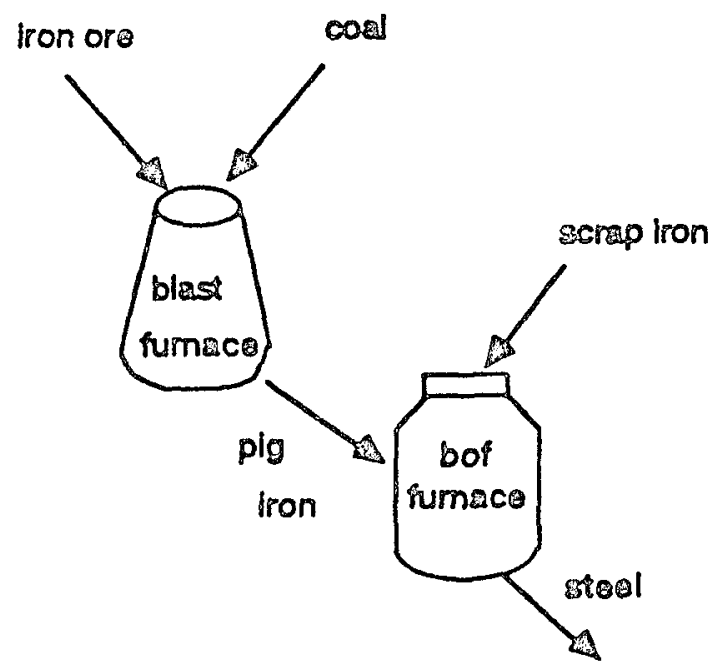

Figure 3.2 Steel Production with the Conventional Technology

The direct reduction technology which is shown in Fig. 3.3 was in use in the other two plants. In this technology iron ore is combined with natural gas under pressure in the direct reduction unit to reduce the metal to sponge iron. The sponge iron is then combined with scrap iron in an electric arc furnace to produce steel. The economies of scale are weaker in this technology, so that smaller production units are economically viable.

The demand for steel products was growing at about ten percent per year at the time of the study, so the key question was whether to expand the existing plants or to construct new plants. The new plant sites under consideration were both near large natural gas deposits and on the Gulf of Mexico, namely Tampico, northeast of Mexico City, and Coatzacoalcoz in the Yucatan Peninsula. A second question was the choice of technology whether to expand with the conventional technology or with the direct reduction tochnology. A third question was whether to rely on the domestic ores which were declining in quality or on imported ores. 


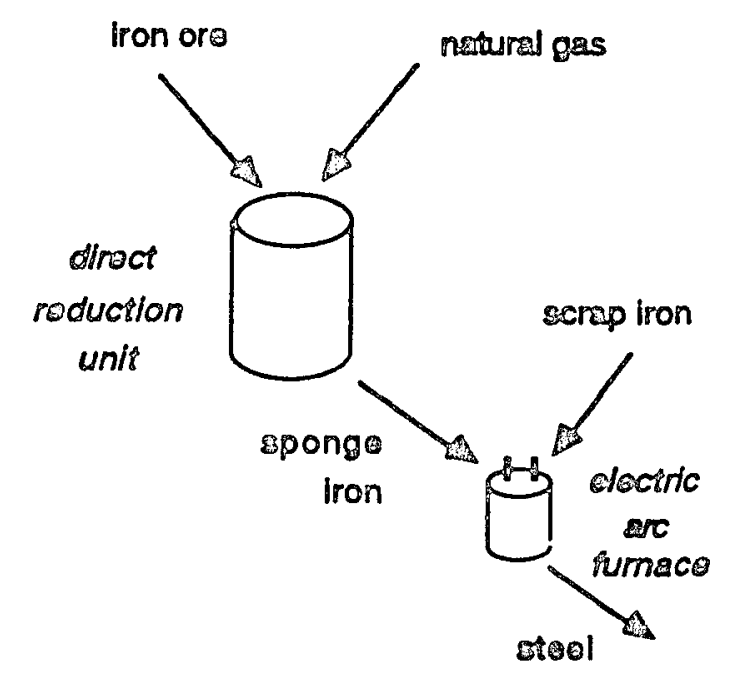

Figure 3.3 Steel Production with Direct Reduction

One of the main results of the study was that the price of natural gas was a key determinant of the best investment strategy. The natural gas price, which was strictly controlled, was a factor of ten less than the world market price. If the price was to remain at that low level then the best investment strategy was to build new direct reduction units. If on the other hand the natural gas price was allowed to rise to the world price then the conventional technology should be used.

Another result was that the Sicartsa location had a strong comparative advantage over the other existing plants and the new plant sites as a location for expansion. Sicartsa is located near a substantial body of iron ore and is a port. Thus it can exploit the existing ore bodies for many years and then efficiently begin using imported ores. Also, at that time the government had a policy of supplying natural gas at prices even below the controlled prices to plants which were located outside of the congested cities. Sicartsa qualified for this lower price and this added further to its odvantage.

A third set of results concemed exports and imports. Imports of iron ore would be small in the near future but would rise to substantial levels as the Mexican ores decreased in quality and quantity during the next twenty years. This represents a substan- 
tial export opportunity for Venezuela and Brazil, both of whom can export high quality iron ore pellets. Thus, even though the model is a single country model it has implications for the potential exports of other countries.

Export and import prices of final products were set at world market levels. At these price levels Mexico was a competitive exporter of steel products. However, an upper bound was placed on exports which limited the amount of exports of final products to a small quantity. A revised version of the model could be used to make a substantial study of the export possibilities of this industry.

In retrospect, the two most serious limitations of the study were (1) the demand projections and (2) the treatment of exports. The demand projections proved to be much too optimistic as the Mexican economy was in a boom in 1979 but has suffered serious declines since then. This is not a problem with the methodology, as a sensitivity test could have been performed to study the effects of different demand projections on the investment strategies, and it was rather a matter of oversight that the sensitivity test was not performed. In fact, if the model had been used for rollover planming it would have been solved each year with new demand projections and the expansion strategy would bave been quickly revised in the face of the declining economy.

Export possibilities were simply not given enough attention in the study. The tight upper bound on exports even prevented the issue from begin addressed seriously. However, the problem here is not in the methodology, since exports could have been specified with a more generous upper bound or export demand functions could have been introduced. The study could now be repeated with a focus on the export possibilities for the indusiry with only minor changes in the structure of the model.

Another limitation is the use of fixed domestic demand instead of demand functions. As was discussed in the previous chapter, demand functions can be used and the problem converted from one of cost minimization to consumer and producer surplus maximization.

A final limitation is computational cost. The plan for the Mexican steel study was to first build an aggregated and then a disaggregated static model, followed by similar dynamic models. The small static and large static models were built with about ten and fifty commodities, respectively. Then two dynamic models were to be constructed. However, only the small dynamic model was built. This model contained about ten commodities, covered 
five time periods and included economies of scale in the investment functions. The resulting programming problem took so long to solve on a mainframe computer that it was apparent that it would not be possible to develop the large dynamic model. Since that time, bowever, great strides have been made in computer speed, so it would probably be quite possible now to develop and solve the lange dynamic model.

In summary, the most important limitations of this study were specification oversights by the investigators. Though there are limitations in the methodology these do not in retrospect seem to have been binding. Finally, the computational limitation, which was important at the time, has been eased substantially since then by increases in computational power.

This study shows how single country sectoral models can be used to analyze dynamic comparative advantage. Economies of scale are included in the investment cost functions and there is a growing domestic demand. Thus the decision to invest and produce for the domestic markets rather than to import can be made while considering the long term rather than just the short term comparative advantage of the industry. Exports at world market prices are also included in the model so that export possibilities can be evaluated against the cost of production (including the investment cost under economies of scale). Moreover, the model includes imports of raw materials and exports or imports of intermediate commodities. A minor change in the model specification would permit export possibilities for raw materials as well. Thus the model permits the analysis of dynamic comparative advantage in the range of products from raw materials through intermediate products to final products.

The model does not explicitly include plants and markets in other countries. That is done in the regional and global models which are discussed later in this chapter. However, let us first consider a single country model for another industry.

\section{b. Fertilizers}

One of the best known single country models is the fertilizer industry study of Egypt by Choksi, Meeraus and Stoutjesdijk (1980). That study included a dynamic model with three time periods and eight plants. Five of the plants were existing and three were sites for new plants. Twenty market areas and eleven final products were included in the model which covered both nitroge- 
nous and phosphatic fertilizers. Fifteen productive units were used, including those which produced su]furic acid, nitric acid, phosphoric acid, and ammonia as well a number of phosphatic and mitrogenous fertilizers.

The model used world prices for exports and imports. Imporis of both raw materials and final products were included as well as exports of final products. Also, various kinds of upper bounds on exports were used in different scenarios. In the basic solution to the model exports were limited to 25 thousand tons per year for each final product, at each plant, in each time period. Also there was an overall export limit of 100 thousand tons per year for all commodities. As the total capacity of the industry was about two million tons per year, this was a tight export limit. Under these limits the basic solution was for the sum of exports of urea, calcium ammonia nitrate (CAN), and single super phosphate (SSP) to be 100 thousand tons per year in each time period. Thus there was apparently a strong potential for exports from the industry even though the basic solution provided for very little expansion of capacity. Therefore the picture is of an industry with substantial excess capacity which could produce at prices below world market prices for some products. With this background wwo alternative export scenarios were considered.

In the first of these scenarios the export bounds were removed but no capacity expansion was permitted. Exports were 440 thousand tons in the first time period, declining to 323 and 206 thousand tons respectively in the second and third periods as domestic demand rose. All of these exports were for a single product (urea) and from a single plant (Abu Kir) which was located at a port on the Mediterranean Sea. So while domestic production was diversified across a number of products, exporis were concentrated in that single product manufactured in the plant that could produce most efficiently for the export market. The point here is got that the best export strategy was to concentrate on a single product from a single plant but rather that the model enabled the analyst to conduct esperiments which would help to find the set of products and plants which were the most efficient exporters in a domestic industry with many plants and many products.

Also, the use of a sectoral model rather than simple cost calculations for export analysis brings out clearly the effects on the production strategy of the remaining domestic plants of increases in exports from one plant. The other plants made substantial adjustments in their production patterns when Abu Kir increased its exports of urea. 
This example also shows another of the limitations of the sectoral models. These models do not normally include the cost of developing export markets by creating foreign trade offices abroad, advertising, etc. Thus the models may overestimate the gains from trade. The methodology permits the inclusion of this cost element, but the practice so far has been to ignore what may be a very costly part of export market establishment.

In the second scenario provision was made for investment to increase the capacity of the industry and upper bounds on total exports were raised to 500,650 , and 845 thousand tons in the three periods. This resulted in a large expansion of the plant at Suez on the Gulf of Suez. The export pattern is shown in Table 3.1.

Table 3.1 Exports in the Second Scenario

$\begin{array}{lcrrr}\text { Plant } & \text { Product } & 1980 & 1983 & 1986 \\ & & & & \\ \text { Kafir El Zayaat } & \text { SSP } & 81 & 0 & 0 \\ \text { Abu Kir } & \text { Urea } & 419 & 277 & 214 \\ \text { Suez } & \text { Urea } & 0 & 373 & 631 \\ \text { Total } & & 500 & 650 & 845\end{array}$

In this solution the export product mix changed across time periods. In the first time period some single super phosphate was exported while in the last two time periods only urea was exported. This flies in the face of the usual expectation that a country will begin exporting a commodity and continue to do so for many years. Since changes in domestic capacity are discrete, however, and since the entire industry will adjust to these changes there is no reason to expect that it is efficient to export the same commodities year after year.

Table 3.1 also shows that one should not expect the same plants to export year after year. In this solution Abu Kir's initial dominant position in the export market was lost to the plant at Suez as that plant expanded its capacity.

These results highlight the fact that while overall export bounds are somewhat arbitrary they may play a useful role in helping the analyst to find those plants which are the most efficient exporters and those export products which are the most competitive.

Recently the World Bank has been involved in large single country studies of the fertilizer industry for India and China. 
These studies are not documented at this time but the interested reader may find them available by the time this monograph appears in print.

\section{c. Other Industries}

Single country industrial models have been prepared for a substantial number of countries and industries. A selection of these models is listed in Table 3.2 by industry and country. Some of these studies are in the library of problems which is available with the GAMS modeling system, (see Brooke, Kendrick and Meeraus (1988)). In such cases the library name of the model is included. In other cases the model was developed in the GAMS language but is not available in the library. In those cases the phrase "in GAMS" appears in the GAMS Library Name column of the table.

\section{Regional}

Regional sectoral models are similar to single country models. All the plants and markets in the various countries are included in the model and the transportation cost is calculated between all plants and markets. Of course shipments of goods from a plant to a market will figure as trade between countries if the shipments cross international boundaries. Since much of intemational trade is between neighboring countries, regional models may be wide enough in geographic scope to cspture a large percent of international trade flows.

Shipments between countries are called intraregional trade fows and shipments to countries outside of the region are called extraregional trade flows. In the model (1) intraregional trade flows are shipments between plants and markets and interplant shipments and (2) extraregional trade flows are exports and imports. 
CH. 3 APPLICATIONS 53

Table 3.2 Single Country Sectoral Models

\begin{tabular}{|c|c|c|c|}
\hline Fodustry & Country & Sudy & $\begin{array}{l}\text { GAMS } \\
\text { Library } \\
\text { Name }\end{array}$ \\
\hline Cement & Yemen & World Bank (1982) & YEMCEM \\
\hline Electric Power & Turkey & $\begin{array}{l}\text { Anderson and } \\
\text { Turvey (1977) }\end{array}$ & TURKPOY \\
\hline Electric Power & India & Gately (1971) & \\
\hline Electric Power & U.S. & Kwun (1986) & in GAMS \\
\hline Fertilizer & Egypt & $\begin{array}{l}\text { Choksi, Meeraus, } \\
\text { and Stoutjesdijk } \\
(1980)\end{array}$ & FERTD \\
\hline Ferilizer & South Am & $\begin{array}{l}\text { Manne and } \\
\text { Vietorisz (1963) }\end{array}$ & VIETMAN \\
\hline Oil Shale & U.S. & Melton(1982) & SHALE \\
\hline Petrochemicals & Mexico & $\begin{array}{l}\text { Jimenez, Rudd, and } \\
\text { Meyer (1982) }\end{array}$ & \\
\hline Petrochemicals & S. Korea & Suh (1981) & KORPET \\
\hline Steel & Mexico & $\begin{array}{l}\text { Kendrick, Meeraus, } \\
\text { and Alatorre(1984) }\end{array}$ & MEXSD \\
\hline
\end{tabular}

An example of a regional sectoral model is the fertilizer industry model for the Andean Common Market which is described in Mennes and Stoutjesdijk (1985). The countries of the Andean Common Market are shown in the schematic map in Figure 3.4. 
At the time the study was initiated all five countries had plans for the expansion of their fertilizer industry. These plans involved expansion of existing plants and construction of new plants at eighteen sites. Therefore a dynamic model with 4 time periods was constructed to include the 18 plant sites as well as 18 market centers. Moreover, the model included 16 productive units, 7 materials, and 13 final products. Interplant shipments of intermediate products were also included. Exports outside the region were limited to no more than 30 percent of a plant's capacity except for one plant in Venezuela and one in Bolivia with strong expori potential which were limited to 70 peroent of capacity.

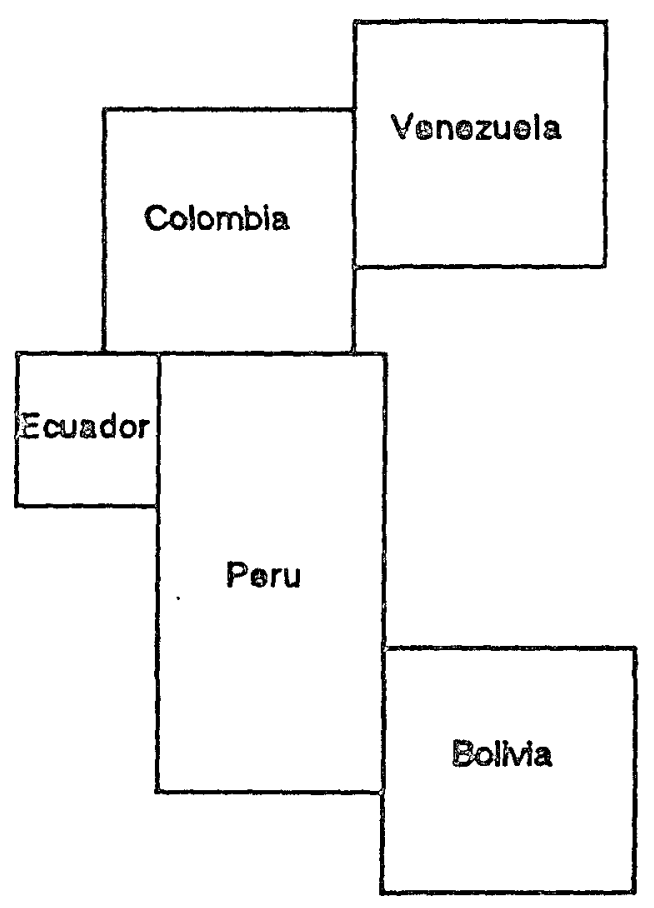

Figure 3.4 The Andean Pact Countries

Since the counties all had existing plans for the expansion of their domestic industries, the first scenario included plant expansions at the times and places envisaged in each country's plan. No other investment was allowed. The result was a total discounted cost of US $\$ 3,150$ million, as shown in Table 3.3 . 
Table 3.3 Tosal Discounted Cost of the Scenarios (in millions of dollars)

Cost Difference

$\begin{array}{lrr}\text { National Expansion Plans } & 3,150 & \\ \text { No Expansion } & 2,762 & -388 \\ \text { Least Cost Strategy } & 2,667 & -95 \\ \text { At Least One Plant in Esch Country } & 2,677 & +10\end{array}$

In contrast, the second scenario provided no investment in any of the countries. As Table 3.3 shows, the result was a decrease in total cost by US\$388 million. Thus the separate national plans were an inefficient solution to the development of the industry. The third scenario was for the least cost expansion plan and decreased the total discounted cost by another US\$95 million. However, this least cost plan did not include expansion in two of the countries (Bolivia and Ecuador), so a fourth scenario was solved in which there had to be expansion of at least one plant in each country. This added only US\$10 million back to the total discounted cost. Thus, some degree of equity was obtainable at relatively little cost.

This type of model is of greatest use when there is serious consideration of a common market or similar agreement between a number of neighboring countries. However, the usefulness of the model is not limited to these cases of cooperation between countries. Since such a large percentage of intemational trade is between neighboring countries this class of models offers a convenient way to study the import and export possibilities of an industry. The model can be constructed for a single country and then solved under various scensrios of different actions by neighboring nations, so es to study the effects on the competitive position of the domestic plants.

Another regional model in a different industry is the gas trade model of Manne and Beltramo (1984) which is called GTM in the GAMS library. This model covers Mexico, the U.S. and Canada with 10 supply zones and 14 market zones for the production of catural gas and its distribution in pipeline systems.

One limitation of regional models is that even though a plant may be competitive within the regional context it might not be competitive on world markets. In order to determine the competi- 
tiveness of a plant in the worldwide context a global model like those discussed in the nert section must be used.

\section{Worldwide}

World models have been built for a number of industries, including oil, copper, steel and petrochemicals. The study carried out by the Organization for Economic Cooperation and Development and the World Bank on the aluminum industry, (Brown, Dammert, Meeraus and Stoutjesdijk(1983)) will be used.

This sectoral model is similar to those discussed earlier in this book except that there is more emphasis on the mining part of the industry. A schematic diagram of the flow of materials is shown in Figure 3.5. Bauxite is mined from open pit mines and sent to refineries where silica and other impurities are removed to produce an aluminum oxide $\left(\mathrm{Al}_{2} \mathrm{O}_{3}\right)$ which is called alumina. The alumina is then reduced to pure aluminum in a smelter by an electrolytic process which removes the oxygen. This process requires a large input of electricity. More weight and volume is lost in the first stage than in the second, so one might expect the alumina refining to be located near the ore deposits and the aluminum smelting to be located near markets or near cheap electric power. In fact all production stages were located until fairly recently near the large markets in North America and Europe; however, the trend in recent years has been for more and more of the bauxite to be produced in the developing countries and increasingly for the alumina and aluminum to be produced there as well, in order to take advantage of low cost electric power.

The OECD-World Bank group developed a world model with 22 mining locations, 30 refining and smelting locations, and 18 market locations. In addition eight different types of bauxite ores were considered, since the exact type of ore makes a substantial difference in the processing cost.

Demand projections were made for the year 2000 and data were obtained on expansion projects that were already commit1ed.Then the model was solved to determine the least cost development of the industry. The result was that about balf of the additional expansion in bauxite mining was in Latin America and the Caribbean, as is shown in Figure 3.6. Most of this expansion 


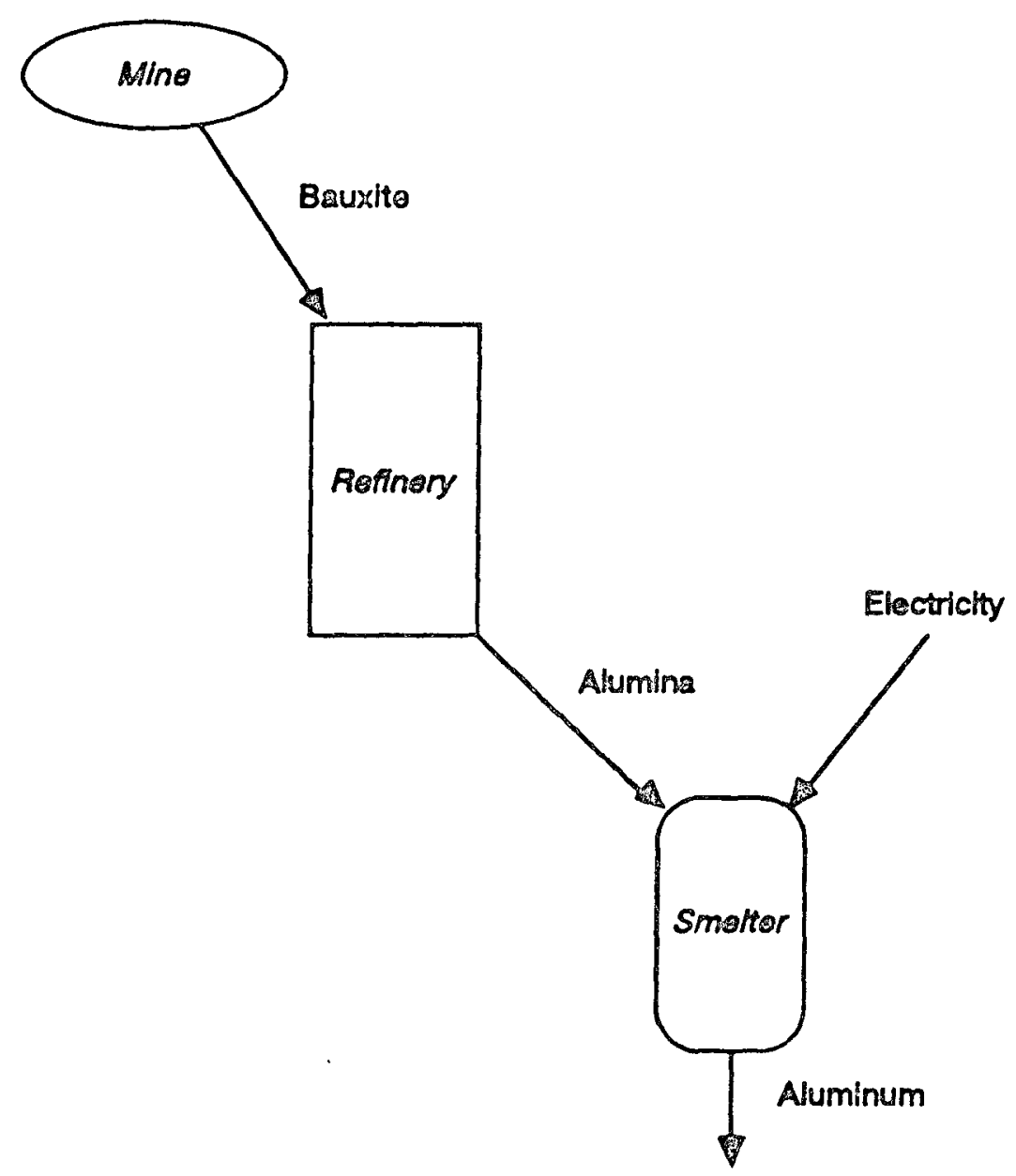

Figure 3.5 Aluminum Production Schema

was in Jamaica, Guyana, Brazil and Venezuela with the largest part being in Jamaica. The large expansion in Asia was mostly in Indonesia. (In this and the following two figures 'Asia' includes Australia but excludes Japan which is grouped with OECD countries and the USSR which is grouped with the Eastem European countries.)

A large part of the alumina capacity expansion was also in Latin America and the Caribbean, as is shown in Figure 3.7. This expansion was divided between Jamaica, Suriname, Venezuela, Brazil and Central America. 


\section{SECTORAL MODELS}

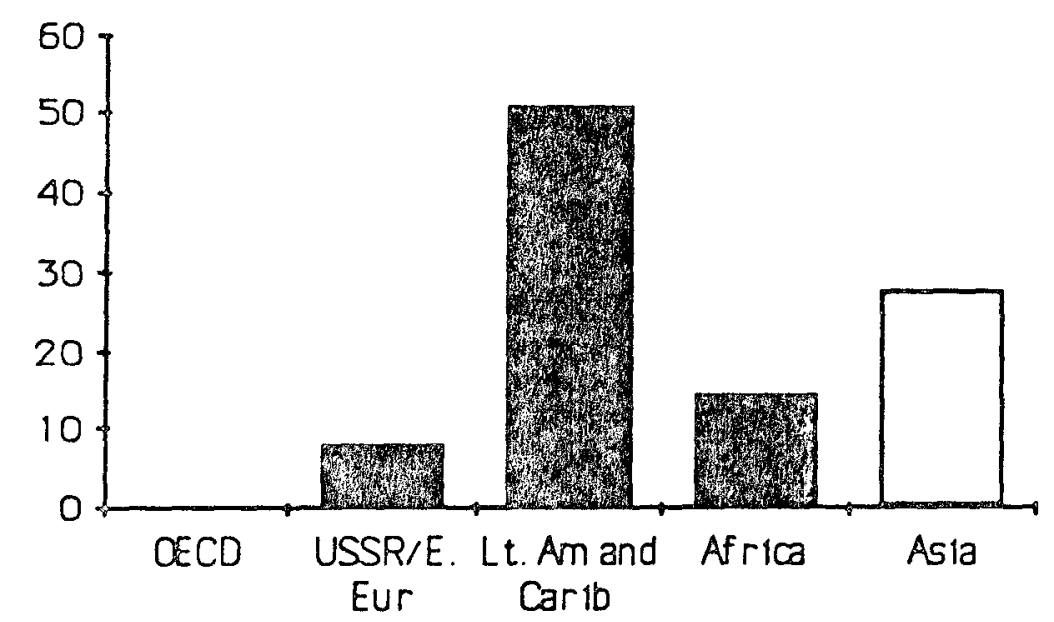

Figure 3.6 Capacity Expansion in Bzuxite Mining (in million metric tons)

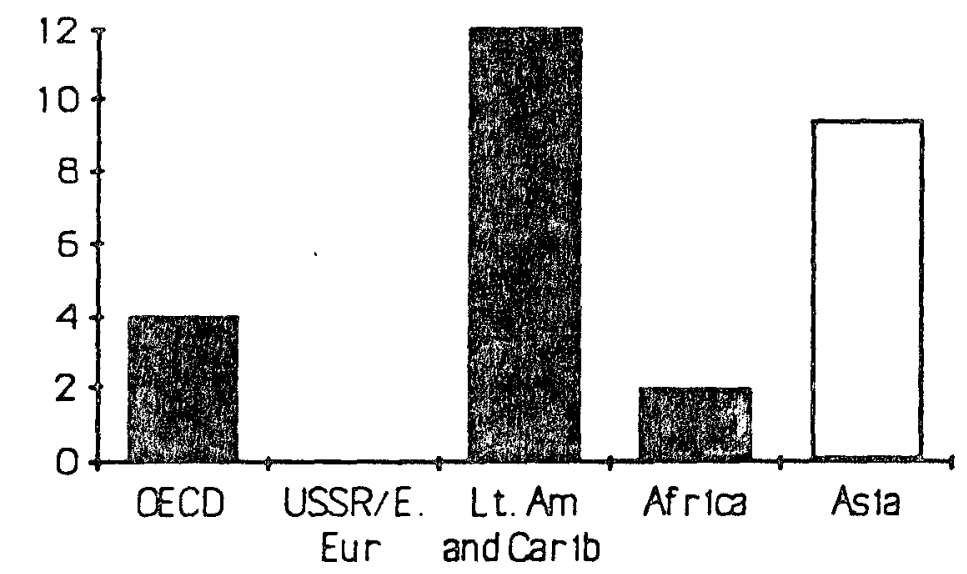

Figure 3.7 Capacity Expansion in Alumina Refining (in million metric tons)

Finally, the expansion in aluminum smelting is shown in Figure 3.8. Here again a large part of the expansion is in Latin America and the Caribbean. Also, much of the expansion is in 
Africa and Asia where inexpensive electric power could be obAined to reduce the alumina to shuminum.

A variety of sensitivity tests were performed. Two of the most interesting of these were on investment costs and on tariffs. In the base run, investment cost were set 10 percent higher in the developing countries than in the developed countries, due to the necessity to develop more infrastructure. As they were concemed that 10 percent was an underestimate of the infrastructure cost however, the investigators increased the figure to 35 percent. The result was that a significant part of the investment was shifted to the developed countries. Therefore, the ability of the developing countries to attract investment depended to an important extent on the cost of infrastructure.

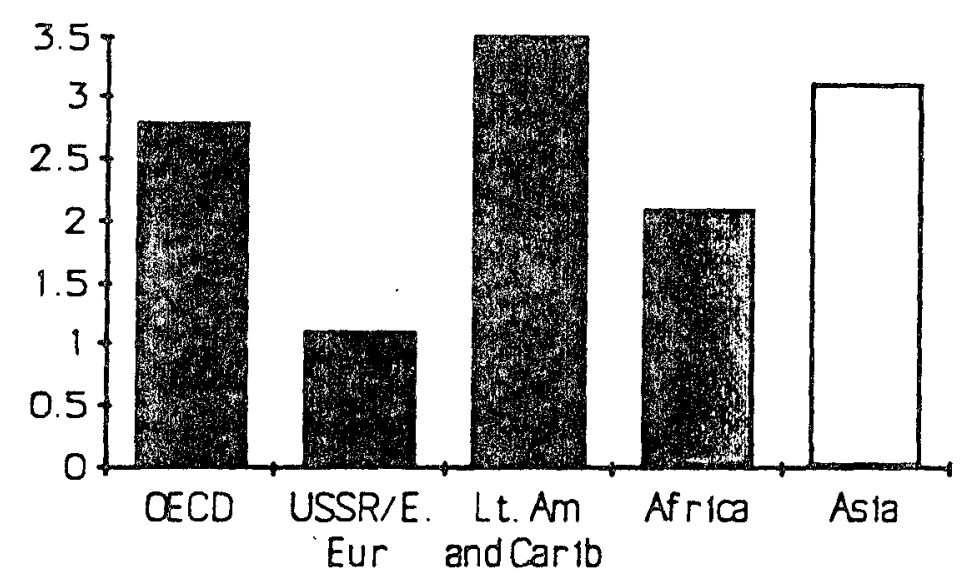

Figure 3.8 Capacity Expansion in Aluminum Smelting (in million metric tons)

This increase in investment cost in the developing countries also led to an interesting phenomenon in which the mining and refining activities in some cases were carried out in a developed country and the smelting activity was done in the developing country. This occurred because of the low electricity cost in the developing country, which offset the higher investment cost. The authors report that in at least one case this kind of trade flow is already occurring: alumina is produced in the U.S. in Louisiana, but shipped to Ghana to be smelted to aluminum.

In the base runs tariffs were not included. When they were added in one of the sensitivity tests it was discovered that these 
60 SECTORAL MODELS

levies were large enough to cause some important shifts in expansion locations. For example Jamaica lost some expansion capacity to Brazil and Venezuela, which had lower tariffs.

In summary, this world model allows one to study the existing trade flows and the dynamic comparative advantage of different countries, not just in one commodity but in a whole set of commodities, from the raw material bauxite through the metal aluminum. Moreover, it allows one to study the effects of increases in capital cost or in tariffs on the dymamic comparative advantage of each country.

There have been such substantial improvements in model specification, algorithms, model development software and computer hardware in the last couple of decades that powerful models of worldwide industries can now be developed and used to analyze the evolution of industries on a global scale. The study references and the GAMS library names of some of these models are given below.

Table 3.4 Global Sectoral Models

GAMS

\begin{tabular}{|c|c|c|}
\hline Industry & Study & $\begin{array}{l}\text { GAMS } \\
\text { Library } \\
\text { Name }\end{array}$ \\
\hline Aluminum & $\begin{array}{l}\text { Brown, Dammert, Meeraus } \\
\text { and Stoutjesdijk (1983) }\end{array}$ & ALUM \\
\hline Copper & Dammert and Palaniappan (1985) & COPPER \\
\hline Petroleum & Langston (1983) & in GAMS \\
\hline $\begin{array}{l}\text { Petro- } \\
\text { chemcials }\end{array}$ & Manouchehri Adib (1985) & in GAMS \\
\hline $\begin{array}{l}\text { Petro- } \\
\text { chemicals }\end{array}$ & Sigurdsson and Rudd (1988) & \\
\hline Steel & Wei (1984) & in GAMS \\
\hline
\end{tabular}

In summary, sectoral models can be used to provide a powerful platform for analyzing dynamic comparative advantage in an 
industry. The analysis can be extended from raw materials through intermediate products to final products and may include multiple productive units as well as alternative processes for producing commodities. Moreover economies of scale in investment cost can be included in the models. The geographic area covered by the model can be a single country, a set of countries in a region, or the entire world.

The models can include tens of commodities, plants, productive units, and markets. These are the limitations at the time of writing but of course these limitations on the size of the model will be eased with the continuing development of algorithms and computer hardware.

The comparative advantage of a product may depend not only on the economic conditions in its own industry but also on developments in other industries. Moreover developments in international trade may bring about changes not only in product prices but also in factor prices. These kinds of changes are either ignored or treated incompletely in sectoral models but are the focus of general equilibrium models like those described in the next chapter. 
Part II

Economy-Wide Models 
4

\section{General Equilibrium}

General equilibrium models are economy wide models with endogenous prices. Mathematically they are systems of simultaneous monlinear equations. No criterion function is specified for the overall model but some equations are derived using the assumption that the individual producers and conEumers optimize their behavior and then the first order conditions from these maximizations are used in the model.

These models are not as useful as the sectoral models for analyzing the dynamic competitiveness of a particular industry; however, they are well-suited for studying the economy wide implications of trade policy. For example, the models may be used to analyze the commodity and factor price effects of changes in export subsidies or import tarifis. Moreover, these price effects can then be traced through the income distribution effects and back into the demand for domestic and foreign goods.

For example, consider a country that has relatively high import duties and which has followed an import substitution development strategy. In such a country a young manufacturing sector may be doing well. However, manufactured goods are high in price relative to world market prices. Then the country changes its development strategy to emphasize exports. The tariffs are reduced. Industrial imports increase and the prices of these goods fall toward world price levels. If the country has efficient agricultural and mining industries then the exports of these industries may increase. Thus the short run income distribution effects of the change in trade strategy are to decrease incomes in import substituting industries and to increase incomes in mining and agriculture. If the agricultural land and mining concessions are held by a relatively small and wealthy group, there will be a demand shift from basics to luxury goods and a concomitant increase in the demand for imported luxury items. This will result in further changes in the balance of payments and in the prices of domestic goods and factors, thereby producing still further changes in the income distribution. 


\section{ECONOMY-WIDE MODELS}

While the broad outlines of the income distribution effects of trade policy changes can be sketched from theoretical models and logical reasoning like that above, multisectoral numerical models are required to gain some idea of the magnitudes. In the example discussed above the gains to the agricultural and mining exporters may be so great and the losses to the import substitution industries so small that the policy shifts produces a substantial aggregate gain for the country. Alternatively, the reverse may be true, with the export gains smaller than the import substitution losses. Therefore the use of numerical models like those outlined in this chapter permit analysis not only of the efficiency gains and loeses from trade but also of the income distribution changes.

The early work on general equilibrium models was done entirely with analytical mathematical methods. For example, fixed point theorems were used by Debreu (1959) to prove the existence of solutions. However, in the last two decades computer efficiencies have increased to the point that substantial computable general equilibrium models (CGE's) can now be solved. Two lines of this numerical work will be singled out for discussion here. 1

The first line follows the research of Stone (1961) on social accounting matrices (SAM's). Graham Pyatt and his collaborators have been the key developers of this thread of work, (see Pyatt and Round (1977 and 1985) and Drud, Grais and Pyatt (1983)). Recently, Ame Drud has given this approach a strong impetus through the creation of a software system which greatly facilitates the development of models of this type (Drud (1989) and Drud and Kendrick (1987)). Drud's system, which is called HERCULES, makes it possible for a comparative novice to develop significant general equilibrium models within a relatively short period of time.

The second line is based on Johansen's (1960) procedure for solving general equilibrium models by linearizing them in a particular way. In Johansen's method nonlinear general equilibrium models are converted to models which are linear in rates of change of the variables. These models can be solved very efficiently, so models with many sectors and household iypes can be developed to permit disaggregated analysis of policy effects. Earlier work along these lines was done by Lance Taylor and his collaborators (see Taylor (1979) and Taylor, Bacha, Cardoso

1 For a thind line of this work see Dervis, de Melo and Robinson (1982). 
and Lysy (1980)). More recently Peter Dixon and his colleagues in Australia have been the principal contributors to this line of research (see Dixon and Powell (1979) and Dixon, Parmenter, Sutton and Vincent (1982)). One of the primary uses of this class of models in Australia has been to analyze the effects of tariff reforms, with special atiention to their repercussion on factor and commodity prices, income distribution, and the balance of payments.

\section{SAM Style Models}

The basic notion in social accounting matrices is the flow of goods and payments between institutions in the economy. For example, simple SAM models contain three institutions, namely factors of production, household types, and production sectors. The payment flows between these institutions can be modeled as shown in Figure 4.1. Beginning on the right hand side of the

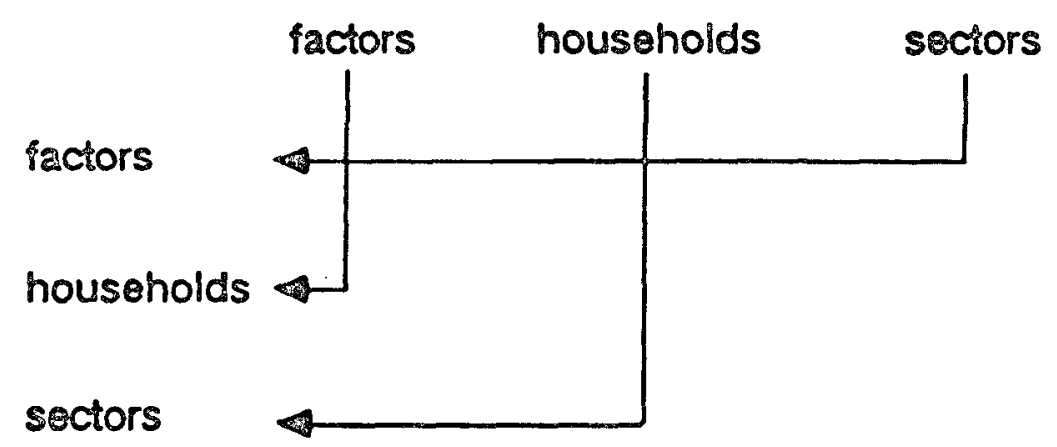

Figure 4.1 Flows in the Economic System

diagram production sectors such as food and clothing pay factors of production such as capital and labor for services rendered. The factors pass this money along to households such as nural and urban households. The households in turn pay the production sectors for purchases of food and clothing. An example of a SAM is shown in Table 4.1. Beginning once 1 The development in this section is based on the Drud and Kendrick (1987)
monograph. 
68 ECONOMY-WIDE MODELS

again on the right side of the rable and following the principle that columns pay rows, the food industry pays 75 to labor and

Table 4.1 Social Accounting Matrix

\begin{tabular}{|c|c|c|c|c|c|c|}
\hline & \multicolumn{2}{|c|}{ Frctors } & \multicolumn{2}{|c|}{ Households } & \multicolumn{2}{|c|}{$\begin{array}{l}\text { Seciors } \\
\text { Food Clothing }\end{array}$} \\
\hline $\begin{array}{l}\text { Factors } \\
\text { Labor }\end{array}$ & & & & & 75 & 85 \\
\hline $\begin{array}{l}\text { Capital } \\
\text { Households }\end{array}$ & & & & & 50 & 60 \\
\hline $\begin{array}{l}\text { Rural } \\
\text { Urban }\end{array}$ & $\begin{array}{l}90 \\
70\end{array}$ & $\begin{array}{l}30 \\
80\end{array}$ & & & & \\
\hline $\begin{array}{l}\text { Sectors } \\
\text { Food } \\
\text { Clothing }\end{array}$ & & & $\begin{array}{l}60 \\
60\end{array}$ & $\begin{array}{l}65 \\
85\end{array}$ & & \\
\hline
\end{tabular}

the clothing industry pays 85 to labor. This total of 160 is passed along by labor as is shown in the furthest left column of the table. Of the total, 90 is given to rural households and 70 to urban households. The urban households also receive 80 from capital for a total income of $70+80=150$. The fourth column of the table shows that the urban households spend 65 of this 150 on food and the remaining 85 on clothing.

In the following section the mathematics of a simple general equilibrium model based on the table above will be presented. Then the computational procedures for solving this type of model will be discussed. This simple model without international trade flows is used to facilitate an introduction. Following the introduction, details will be given of a more complete model which includes exports, imports, the foreign exchange rete and the balance of payments.

\section{a. Mathematics of a Simple Model}

The key variables of SAM-based general equilibrium models are price, quantity, and income. These variable for each of the institutions of (1) sectors, (2) factors, and (3) household are shown below in Table 4.2. The price of commodities is 
CH. 4 GENERAL EOUIUBRIUM 88

Table 4.2 Price, Quantity and Income Variables

$\begin{array}{lccc} & \text { price } & \text { quantity } & \text { income } \\ \text { sector } & p_{s} & q_{s} & y_{b} \\ \text { factor } & p_{f} & q_{f} & y_{f} \\ \text { household } & p_{b} & q_{b} & y_{b}\end{array}$

denoted by $p_{s}$ and the price of factors by $p_{f}$. In models with two sectors like the one in the SAM above, the commodity prices would be the prices of food and clothing. Similarly, the prices of factors would be the wage rate for labor and the interest rate on capital. The notion of the price for households, $p_{b}$, is less familiar but extremely useful. Using the SAM above there would be a price for rural households and a price for urban households. These are price indices like the consumer price index. Should there be different price indices for different types of households? By all means. In economies where the mix of goods consumed by rural families is sharply different from that for urban families the price deflator for the two groups may be quite different. The inclusion of these household price variables in the model allows the analyst to study the effects of changes in relative prices on the well-being of different groups in the society.

All the variables in Table 4.2 have a single subscript, i.e. they apply to a single institution. In contrast, the other variables in the model, as shown in Table 4.3 , all have two subscripts since they represent flows of goods and payment

Table 4.3 Other Variables

payment

$$
t_{\text {to }}^{t_{\text {f }}}
$$

comrnodity

$c_{\text {fa }}$

$c_{\mathrm{B}}$

household to sector

between the various institutions. The subscripts on the payment variables follow the SAM convention mentioned above that 


\section{TO ECONOMY-WIDE MODELS}

payments are from columns to rows. Thus the variable $t_{\text {fos }}$ is a payment from one of the sector columns $s$ to the factor rows $f$, i.e., it is a wage or interest payment from the food or clothing sector to either capital or labor. In contrast, the commodity flows follow a mixed convention and can sometimes be read as a flow from the first subscript to the second. For example the variable $c_{t}$ is the amount of factor $f$ which is used in sector $s$. On the other hand, the variable $c_{k x}$ is the flow of purchased goods from sector $s$ to household $b$.

There are four groups of equations in the model. Three groups are for the institutions used above and the fourth group is a set of equations which link together the three institutions. The equations for the first institution, the sectors, are shown in Table 4.4. In this and the following tables there are columns for

Table 4.4 Sectoral Equations

$$
\begin{array}{ll}
\text { price, } \\
\text { share or price- } \\
\text { quantity payment quantity }
\end{array}
$$

1. Output

$$
q_{s}=b_{s} \prod_{1} c_{s}^{s}
$$

2. Inputs

$$
c_{f t}=a_{f z} q_{s} p_{s} / p_{f}
$$

$y, p_{s} q_{1}$

$t_{\text {if }}{ }^{a x} p_{f} c_{f t}$

quantity, price and price-quantity equations. The equations in the price group also include some share and payment equations. Those in the last group all include price times quantity terms.

The first equation in the model is the production function shown in the first column of the output row in Table 4.4. In this example the production function is Cobb-Douglas; however the HERCULES system which is used to solve this class of models permits many different production function specifications, including constant and variable elasticity of substitution. For the SAM above the production function would include capital and labor inputs each raised to an exponent and multiplied times one another. 
CH. 4 GENERAL EQUIUBRIUM 71

The equation below the production function is a factor demand eqration. It shows that the demand $c_{\text {s }}$ for each factor $f$ by sector $s$ is (1) a positive function of the output level $q$, of the sector and of the price for the commodity $p_{3}$ and (2) an inverse function of the price of the factor $p_{f}$.

Table 4.5 provides the factor equations. For example, the equation in the first row of the table would give the factor income for labor as the wage $p_{f}$ times the quantity of labor provided $q_{l}$. The equation in the second row gives the transfer of

Table 4.5 Factor Equations

q

p

$\mathrm{pq}$

3. Income

$$
y_{f}=p_{f} q_{f}
$$

4. Transfer

$$
t_{\Delta f}=a_{\Delta f} y_{f}
$$

income from factors to households. For example, thinty percent of labor income might go to urban households and seventy percent to rural households.

The consumption equations are in the second column and first row of Table 4.6. They are share equations in this simple model. They show that a share $a_{\text {sh }}$ of the income of

Table 4.6 Household Equations

q

\section{Consump}

6. CPI p

$$
t_{\text {a }}=a_{\text {出 }} y_{b}
$$$$
t_{\text {出 }}=p_{s} c_{\text {出 }}
$$

pq

$$
p_{B}=\prod_{f} p_{s}^{\prime d h} \quad y_{b}=p_{b} q_{b}
$$

households $y_{h}$ is spent on goods from sector $s$. The price equations just below the consumption equations provide the means of calculating the price index for each type of household. The prices are raised to an exponent which is the share that each 
72 ECONOMY-WIDE MODELS

household spends on the good. These terms are then multiplied times one another to create the index.

The last group of equations consists of those which provide the linkage between the institutions. They are shown in Table 4.7. For example, the first equation indicates that the income

Table 4.7 Linkage Equations

$\mathbf{q}$

8. Factors

9. Households

\section{$\mathbf{p}$}

$$
y_{s}=\sum_{i} t_{m}
$$

$$
y_{f}=\sum_{z} t_{f i}
$$

$p q$

$$
y_{B}=\sum_{f} t_{b P}
$$

received by each sector will be the sum over all household types of the payments made by each household type for goods from the sector.

A summary of all of the equations of the model is provided in Table 4.8. The model used here is a slightly simplified version of the equivalent model in Drud and Kendrick (1987). Table 4.8 and the list of variables above can be used to count equations and unknowns. This is done in some detail in the book; however, it is more useful here to move on to a discussion of the computational methods for solving the model. 
CH. 4 GENERAL EQUILIBRIUM 73

Table 4.8 Equations of the Complete Model

$$
\begin{gathered}
\text { price, } \\
\text { share or } \\
\text { payment } \\
\text { price- }
\end{gathered}
$$

$q$

$$
p
$$

$p q$

Secrors

1. Output

$$
g_{8}=b_{8} \prod_{8} c_{83}^{s}
$$$$
y_{3}=p_{8} q_{3}
$$

2. Inpuis

$$
c_{63}=a_{88} q_{8} p_{6} / p_{f}
$$

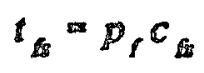

Fractors
3. Income
$y_{f}=p_{f} q_{f}$
4. Transfer
$t_{a r} a_{a f} y^{t}$
Households
5. Consump

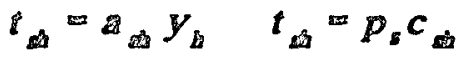
6. CPI

$$
p_{b}=\prod_{f} p_{b}^{g} \quad y_{b}=p_{h} q_{b}
$$

\section{Linkage}

7. Sectors

$$
y_{s}=\sum_{s} t_{d x}
$$

8. Factors

$$
y_{f}=\sum_{s} t_{t s}
$$

9. Households

$$
y_{b}=\sum_{f} t_{b P}
$$


b. Computation of a Simple Model

One method of solving SAM-based general equilibrium models is to use the HERCULES software. This software uses the GAMS system to provide a user-friendly interface for input and output but has separate software for the analysis and solution of the general equilibrium model. HERCULES is an innovative new type of software in that the user need only specify the institutions and the functional forms of the production and consumption functions. The HERCULES system has a knowledge base which enables it to then construct the mathematical model and solve it. Therefore, the user of the HERCULES system need not be able to develop and maintain the mathematical model but rather can confine his or her attention to the economic specification of the model. Appendix $4 \mathrm{~A}$ gives an idea of the type of input which is required for the HERCULES system by discussing portions of the input for a simple model which follows the SAM above.

\section{c. A Trade Model}

The key element of the trade model is the separation of the commodity accounts into four groups as is shown in Figure 4.1.

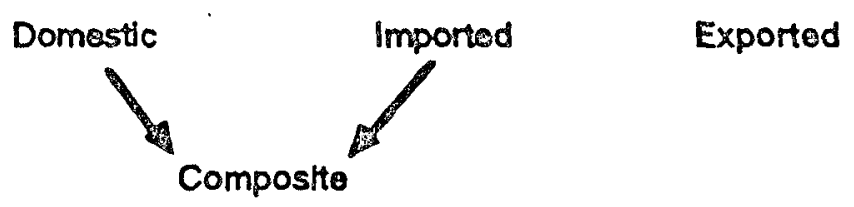

Figure 4.1 Types of Commodities

As might be expected, there are imported, exported and domestically produced commodities. The new element is the composite commodities, which are blends of domestic and imported goods. The essential notion is that within a given sector, say clothing, the domestic good and the imported good are not identical but can be viewed as substitutes for one another. Therefore, the model treats domestic and imported goods as inputs to the production of a composite good. There 
is substitution between the domestic and imported goods, depending on their relative prices. Total domestic consumption can then be measured as the demand for the composite good. Exports, on the other hand, stand alone and compete with other goods on the world market. Appendix 4A contains a description and a complete statement of the trade model.

From the discussion here and in Appendix 4A of the input for solving SAM based general equilibrium models with HERCULES one can see that there are price elasticities of demand for exports, and elasticities of substitution between domestic and imported commodities. Also, there is allowance for tariffs and subsidies and the capability for changes in these elements to be propagated through the entire price structure of commodities and factors in the model. Thus this type of model would be suitable for a numerical investigation of the effects of changes in trade policy like the one discussed for the hypothetical country at the beginning of this chapter.

For that case one would begin with (1) high duties on light industrial commodities and (2) an overvalued exchange rate. Prices for domestic agricultural and mining products would be lower than international prices and prices for light industrial commodities would be above world prices. These prices and exchange rates would produce a solution with high factor prices for those factors used intensively in import substituting industries. Therefore the solution would provide an income distribution favoring those who own the industrial goods plants. A reduction of tariffs on light industrial goods and a devaluation of the exchange rate would result in more imports of light industrial goods and more exports of agricultural and mining goods. The resulting change in commodity and factor prices would then turn the income distribution away from the owners of light industry and toward the owners of farms and mines.

\section{d. Limitations of SAM-based General Equilibrium Models}

As was indicated above, the principal limitation of this type of model is that it is based on comparative statics. Comparative statics is not the same as dynamics, because the models have no distributed lag relationships and therefore no way of estimating the time it takes for policies to take effect. It is possible to string together a series of single period models and to connect them with capital accumulation relations; however, this still suffers 
from the problem that the consumption, investment, export and import equations have no distributed lags and therefore the timing of policy effects is lost. Though a general equilibrium model may so indicate, devalustions do not produce immediate changes in exports and imports. Rather the effects can be spread over several years and the timing of these effects can be important to the policy. Macroeconometric models are well suited for analyzing these changes over time, but most presentday general equilibrium models are not.

Also, there are two limitations which are particular to the HERCULES system. The first is that all prices are one in the base period. This means that it is not informative to compare the price of food to the price of clothing in the base period. It is possible to get around this limitation by multiplying the results from HERCULES by a set of price indices that provide relative prices. For some kinds of analysis it will be important to do this.

The second limitation is that one feels uneasy about the possibility, that at some stage in the analysis it will be desirable to use a function specification which is not available in the HERCULES data base. This concem is fundamental to all knowledge-based systems. The system is extremely helpful if one wants to do studies that are encompassed by the knowledge base, but not very helpful if it is necessary to go outside of this range. However, the HERCULES system has been in use for some time now, so almost all of the specifications used by economists are included. Therefore, the HERCULES system is a useful way for most general equilibrium modelers to begin their work, since it provides easy entry. Moreover, the specifications available are broad enough to encompass the modeling interest of almost all projects. However, some advanced users will want freedom rather than help and for those users a less structured approach may be useful.

Finally, there is a limitation which is common to all general couilibrium systems - size. Frequently, the size of the model is limited by data availability. However, there are times when the data are available for developing disaggregated models and then computational methods may stand as a bottleneck. In such cases the Johansen method which is discussed next may be the method of choice because the linearization which is employed greatly increases the computational efficiency. Also, the Johansen method is not restricted by knowledge base and is therefore more open ended. 


\section{Johansen Style Models}

Johansen style models are solved in a linearized form where all the variables are rates of growth; however, it is easier to understand the models in their original nonlinear form where the variables are levels instead of rates of growth. Therefore, the presentation here begins with the model using levels and then proceeds to the model using rates of growth.

As was indicated earlier in this chapter, the most active research group currently using this methodology is the Australian group at Project Impact in Melboume. This group developed a small version of their ORANI model early in the work on that project. That model is simple enough to be presented in a few pages and yet complicated enough to demonstrate the key parts of the methodology. For a more complete discussion of the small ORANI model see Kendrick (1984), which is the prototype for the presentation here, or use the original, which is in Dixon (1979) and Dixon, Parmenter, Sutton and Vincent (1982). For an application of this class of models to the U.S. economy see Colias (1985).

\section{a. The Model Using Levels}

The five groups of equations in the model are

$$
\begin{aligned}
& \text { consumption } \\
& \text { production } \\
& \text { prices } \\
& \text { market clearing } \\
& \text { miscellaneous }
\end{aligned}
$$

The consumption and production equations are submodels in which consumer and producer behavior are respectively, optimized. This optimizing behavior gives rise to consumer demand equations on the one hand and producer demand equations for commodities and factors on the other hand. The price equations determine domestic prices from input-output relationships and from world prices and exchange rates. The 
market clearing equations assure that demand and supply are in balance for commodities and factors.

\section{Consumption}

In this model, as in the SAM, there is a separation between domestic and imported commodities but in this case there are no composite commodities. There is a set of commodities $C$ and a set of sources, $S$. For the simple model at hand there are two commodities and two sources, i.e.

$$
\begin{aligned}
& C=\{\text { food }, \text { clothing }\} \\
& S=\{\text { domestic }, \text { imported }\}
\end{aligned}
$$

Therefore there are consumption functions for $c_{c s}$, i.e. for each commodity and source. These functions have the form

$$
\begin{array}{ll}
c_{c s}=f\left(p_{c s}, y^{c}\right) & c \in C \\
& s \in S
\end{array}
$$

where

$$
\begin{aligned}
& c_{c s}=\text { consumption of commodity } c \text { from source } s \\
& P_{c s}=\text { price of commadity } c \text { from source } s \\
& y^{\varepsilon}=\text { expenditure by households }
\end{aligned}
$$

The consumption functions (1) are derived from a two-level optimization problem. The top level is a fixed coefficient form that permits no substitution between commodities

$$
\begin{aligned}
U & =\min _{c \in C}\left\{u_{c} / v_{c}\right\} \\
\text { where } & \\
U & =\text { total utility } \\
u_{c} & =\text { utility from commodity } c \\
v_{c} & =\text { utility per unit of commodity } c
\end{aligned}
$$

The assumption of no substitutability between commodities results in consumption functions which include only the price of the domestic and imported commodity and not the prices of other commodities as well. This assumption is made for simplicity in models with a large number of commodities and where there is 
CH. 4 GENERAL EQUIUBAIUM 79

substitution between commodities from domestic and imported sources. The assumption of substitution between commodities from different sources is embodied in the equation below. Thus

$$
u_{c}=\prod_{s \in S} c_{c s}^{a} \quad c \in C
$$

the utility from each commodity is a multiplicative function of the consumption of that commodity from different sources, i.e., domestic and imported.

Finally, consumption is limited by the household budget constraint

$$
\sum_{c \in C S \in S} \sum_{c s} p_{c s}=y^{e}
$$

The left hand side of the constraint is summed over both commodities and sources.

One other aspect of consumer demand remains to be treated. This is the demand for exports, i.e., the demand by foreigners for domestic goods. This is embodied in functions of the form

$$
\text { where } \begin{array}{ll}
p_{c}^{e}=e_{c}^{-r_{c}} d_{c}^{f} & c \in C \\
p_{c}^{*}=\text { export price of good } c & \\
e=\text { exports } & \\
d^{f}=\text { shift factor in demand for exporis } \\
S D=\{\text { domestic }
\end{array}
$$

Thus the export demand for each domestic commodity is a nonlinear function of its foreign curnency price.

\section{Production Functions}

Production functions are used to determine the demand for intermediate inputs and for factors. In this model there are two aspects of production: (1) the activity level $z$, for each industry and (2) the production level $q_{d}$ for each commodity in each industry. This arrangement permits the production of more than one product from each industry. The activity level for the in- 


\section{ECONOMY-WIDE MODELS}

dustry is constrained by commodity and factor inputs, and in sum the production level for each commodity is constrained by the industry activity level.

The activity level is determined, as shown below, by a Loontief fixed-coefricient production function. This functional

$$
z_{1}=\min \left[\frac{f_{1}}{a_{1}^{f}}, \frac{x_{11}^{n}}{a_{11}}, \frac{x_{21}^{a}}{a_{2 l}}, \ldots\right] \quad i \in I
$$

where

$$
\begin{aligned}
f_{l}= & \text { Cobb-Douglas combination of primary } \\
& \text { factor inpus to industry } i \\
s_{d}^{\prime \prime}= & \text { inputs to industry } i \text { of a Cobb-Douglas } \\
& \text { combination of commodity } c \text { from domestic } \\
& \text { and foreign sources }
\end{aligned}
$$

form permirs no substitution between factors and commodities or between commodity inputs. This assumption is made for simplicity and to focus attention on the substitution between different factors and between commodities from domestic and imported sources.

The assumption of substitution between factors is embodied in the function

(7)

$$
f_{1}=k_{1}^{a_{l}^{k}} a_{1}^{l} \quad \quad i \in I
$$

where

$$
\begin{aligned}
& \mathbb{1}_{1}=\text { capital input in incustry } i \\
& l_{1}=\text { labor imput in industry } i \\
& \alpha_{1}=\text { copital coefficient for industry } i \\
& \alpha_{1}^{l}=\text { labor coefficient for industry } i
\end{aligned}
$$

which has the Cobb-Douglas form. Similarly, the commodity imputs from different sources are assumed to be substitutable 
CH. 4 GENERAL EQUIUBRIUM 81

(8)

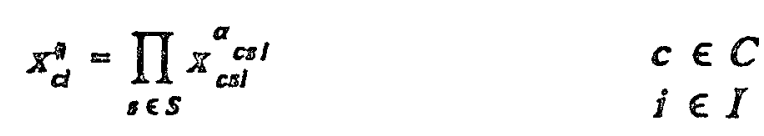

where

$x_{c s 1}$ input in industry $j$ of commodity $c$ from source $s$

$\alpha_{c=1}=$ coefficient

Once the activity level for the industry is determined, then production levels can be computed by solving the following optimization problem

$$
\max \xi_{1}=\sum_{c \in C} \sum_{s \in S D} p_{c s} q_{d} \quad \text { i } \in I
$$

subject to

$$
\left[\sum_{c \in C} \beta_{d} q_{d}^{2}\right]^{1 / 2}=z_{1} \quad i \in I
$$

where

$\beta_{a}=$ pasitive parameter

$q_{d}$ output of commodity $c$ by industry $i$

$z_{1}$ activity level for incustry $i$

This specification permits multiple outputs from each industry. For example the model might include the automobile industry and yet be disaggregated enough to include the production of cars and trucks by that industry.

\section{Price Equations}

The main set of price equations in the model ensures that the value of all outputs in an industry must equal the value of all intermediate inputs and factor inputs.

(11) $\sum_{c \in C} p_{c s} q_{d}=\sum_{\epsilon \in C} \sum_{s^{\prime} \in S} p_{c s^{\prime}} x_{c s^{\prime} l}+p^{k_{i}} k_{1}+w I_{1}, \quad \begin{aligned} & j \in I \\ & s \in S D\end{aligned}$

Domestic prices are related to international prices through the exchange rate and the export subsidy rate with the equation 
where

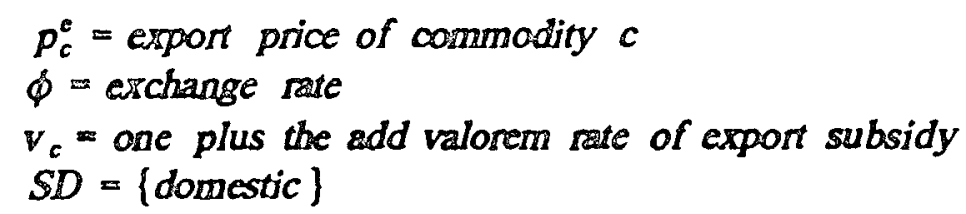

Also, domestic prices are related to intemational prices on the import side with the relationship

(13)

$$
\begin{array}{ll}
p_{c t}=p_{c}^{m} t_{c} \phi & s \in S F \\
& c \in C
\end{array}
$$

where

$$
\begin{aligned}
& p_{c}^{m}=\text { import price of commodity } c \\
& i m \text { one plus the ad valonem rate } \\
& S F=\{\text { imported }\}
\end{aligned}
$$

Through these relationships, changes in import duties, export subsidies and exchange rates are reflected in domestic prices. These changes in tum cause substitutions between domestic and imported commodities which are used in final consumption and as intermediate goods in production.

\section{Market Clearing Equations}

The market clearing equations require that the production of domestic commodities must equal uses of those commodities

$$
\begin{aligned}
& \sum q_{d}=\sum x_{c o l}+c_{c s}+c_{c} \quad s \in S D \\
& c \in C
\end{aligned}
$$

as intermediate inputs, for consumption, and for export. Similarly, use of the factors labor and capital cannot exceed their availability. 
CH. 4 QENERAL EQUIUBRIUM 83

(15)

$$
\text { where } \begin{aligned}
& \sum_{l=l} l_{l}=l^{f} \\
& I^{f}=l_{\Delta} b \text { or force } \\
& k_{I}=x_{I}
\end{aligned}
$$

(16)

where

$$
x_{1}=\text { exogenously given capital stock for sector } i
$$

The labor force constraint is economy-wide but the capital constraint is for each sector. These functions embody the assumptions that labor can move freely from industry to industry but that capital equipment cannot.

Miscellaneous Identities

This group includes the trade equations as well as a consumer price index, a wage equation, and a real consumption equation. Consider first the trade equations. Total imports are a sum over all commodities, of imported intermediate inputs

$$
m^{T}=\sum_{c \in C} \sum_{s \in S}\left(\sum_{I \in I}\left(p_{c}^{z x} x_{c s i}\right)+c_{c s}\right)
$$

plus final consumption imports. Total exports equals the sum, over all commodities, of the value of exports of each

$$
e^{T}=\sum_{c \in C} p_{c}^{e} e_{c}
$$

commodity. The balance of trade is then simply exports minus imports

$$
b=e^{T} \cdot m^{T}
$$

The consumer price index is the product of the prices of all domestic and imported commodities each raised to a power. 
84 ECONOMY-WIDE MODELS

$$
p^{c}=\prod_{c \in C s \in S} \prod_{c s}^{u}
$$

The power in each case is the share of that commodity in total consumption.

The wage rate is determined by an exogenous wage shift factor and by the consumer price index. Thus when prices rise

$$
\text { where } w=\left(p^{c}\right)^{\theta} w^{s}
$$

$$
\begin{aligned}
& \theta=\text { parameter determing the degree to which } \\
& \text { price inflation drives wage infation } \\
& w^{s}=\text { wage shift variable }
\end{aligned}
$$

there will be an increase in wages. This is like the cost of living adjustment (COLA) in the U.S. economy.

Finally, real consumption is determined by deflating nominal consumption by the consumer price inder.

$$
c^{s}=y^{e} / p^{c}
$$

This expression enables the analyst to trace the effect of tariff and exchange rate changes on real consumption in the economy.

\section{b. The Model Using Rates of Change}

As discussed earlier, the Johansen models are solved by linearizing them in terms of rates of growth. An example of this procedure is drawn from the familiar Cobb-Douglas production function. 
(23)

$$
\text { where } \begin{aligned}
q & =k^{\alpha} 1^{\beta} \\
q & =\text { output } \\
k & =\text { capital stock } \\
l & =\text { labor force } \\
\alpha & =\text { capital coefficient } \\
\beta & =\text { labor coefficient }
\end{aligned}
$$

This is a nonlinear function using the levels of the variables. In order to transform it to a linearized function using rates of growth, first takes the log of both sides of the equation to obtain

$$
\ln q=\alpha \ln k+\beta \ln I
$$

Then take the derivative with respect to time to obtain

$$
\frac{1}{q} \frac{d q}{d t}=\alpha \frac{1}{k} \frac{d k}{d t}+\beta \frac{1}{l} \frac{d l}{d t}
$$

Finally write the equation in terms of rates of growth

$$
\tilde{q}=\alpha \tilde{k}+\beta \tilde{I}
$$

where

$$
\begin{aligned}
& \tilde{q}=\frac{d q / d t}{q}=\text { rate of growth of output } \\
& \tilde{k}=\frac{d k / d}{k}=\text { rate of increase of capital stock } \\
& \tilde{I}=\frac{d / d t}{l}=\text { rate of growth of labor }
\end{aligned}
$$

Eq. (26) can be read 'the rate of growth of output will be a weighted sum of the rates of growth of the capital stock and the labor force'. Each equation in the linearized version of the model will be in this form, i.e., a weighted sum of growth rates.

An example from the small ORANI model is the equation for the price of imported goods. In the levels version of the model this is Eq. (13) 
65 ECONOMY-WIDE MODELS

$$
p_{c s}=p_{c}^{m} t_{c} \phi \quad c \in C
$$

The equivalent equation in the linearized version of the model is

$$
\tilde{p_{c s}}=\tilde{p_{c}}+\tilde{t_{c}}+\tilde{\phi}
$$

which can be read 'the rate of change of the price of imported goods is equal to the rate of change of the international price of the good in foreign currency plus the rate of change of tariffs plus the rate of change of the foreign exchange rate. The linearized version of all of the equations of the model is presented in Appendix 4B.

\section{c. Computation}

Computational methods for the solution of large Johansen style models have been developed in Project Impact in Australia by Codsi and Pearson (1988). The system is called GEMPACK. It operates on VAX and IBM PC computers among others. Alternatively, the GAMS system can be used for colving Johansen style models. Appendix $4 B$ contains a GAMS statement for the linearized version of the small ORANI model.

\section{Comparative Advantage of General Equilibrium Models}

As was discussed earlier in this chapter general equilibrium models are usually not dynamic, do not include spatial information, and do not include economies of scale - all of which are crucial to determining dynamic comparative advantage. However, the study of comparative advantage is not simply a matter of finding the best exporting industries and projects. Rather the subject also has to do with import duties, export subsidies and exchange rates - all of which are modeled very well with general equilibrium models. Also, the income distribution effects of trade policy are a matter of great concern in most 
countries and the general equilibrium models are the method of choice for this type of analysis.

In addition, there is much to be said for using a general equilibrium framework to obtain a conceptual overview of the economy. For example, the use of a SAM, even apart from the HERCULES software can provide substantial insights into the structure of an economy.

Comparative advantage among models is itself dynamic. In the past computational general oquilibrium models have been too aggregated to provide much insight about comparative advantage. However, the advances in recent years in computational hardware and the development of modeling systems like GAMS, HERCULES and GEMPACK are making it possible to develop, solve and maintain highly disaggregated computational general cquilibrium models. 


\section{Appendix 4A \\ SAM Style General Equilibrium Models}

This appendix contains the computer statement in HERCULES of two general equilibrium models which are drawn from Drud and Kendrick (1987).

\section{Simple Model}

Three are three principal parts to the input: (1) the set of accounts, ACC, (2) the account table, AT, and (3) the cell table, CT. The cell table in tum has two parts: (a) the SAM and (b) the specification table.

The first two parts of this input, namely the list of accounts and the account table is shown below in Table 4A.1. The list of accounts includes the two factors (labor and capital), the two

Table 4A.1 List of Accounts and Account Table

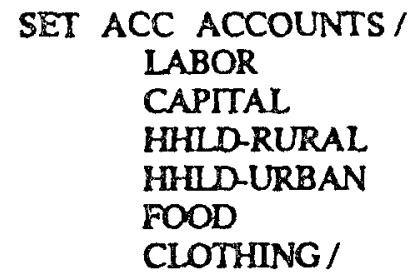

TABLE AT ACCOUNT TABLE

$\begin{array}{llc} & \text { TYPE } & \text { FIX } \\ \text { LABOR } & \text { MF } & \mathbf{Q} \\ \text { CAPITAL } & \text { MF } & \text { Q } \\ \text { HHLD-RURAL } & \text { INSTC } & \\ \text { HHILD-URBAN } & \text { INSTC } & \text { NP } \\ \text { FOOD } & \text { AC } & \\ \text { CLOTHING } & \text { AC } & \end{array}$

household types (rural and urban), and the two sectors (food and clothing). The Type column in the Account Table in the 
APP. $4 A$ A SAM STYLE GENERAL EQUIUBRIUM MODEL 89

bottom part of Table 4A.1 indicates which accounts belong to which institution. For example labor and capital are factors (MF - market factors), rural and urban households are households (INSTC - institutions which are consumers), and food and clothing are sectors (AC - activity accounts). Also, the Fix column in the Account Table is used to indicate which variables are fixed exogenously and whether the price, quantity, or income is fixed. In the case at hand the labor and capital quantities (Q) are fixed. Finally, the NP symbol indicates that the price index for urban households is fixed as the numeraire in the model.

In summary, the account list and table are used to associate accounts with institutions and to determine which variables are fixed exogenously.

The next portion of the input is the SAM from Table 4.1. The only difference between the table presented above and the one in Table 4A.2 is that the table here is in a form that can be read by the computer.

Table 4A.2 The SAM

TABLE SAM SOCIAL ACCOUNTING MATRIX

LABOR CAPTTAL HHLD-RURAL HHLDURBAN FOOD CLOTHING

$\begin{array}{lll}\text { LABOR } & 75 & 85 \\ \text { CAPITAL } & 50 & 60\end{array}$

HHLD-RURAL 90 . 30

HHLDURBAN $70 \quad 80$

FOOD

$60 \quad 65$

CLOTHNG $\quad 60 \quad 85$

The specification table below is used to stipulate the functional form of some of the elements of the model. The CD's in the top right-hand comer of Table 4A.3 indicate that the 
SO ECONOMY-WIDE MODELS

Table 4A.3 The Specification Table

TABLE SPEC(ACC,ACC) SPECIFI CATEONS TABLE

LABOR CAPITAL HHLD-RUQAL HHLDURBAN FOOD CLOTHING

LABOR

CAPTTAL

CD CD

HHLD-RURAL IDIST DIST

HHLDURBAN IDIST IDIST

VSHR VSHR

CLOTHING VSHR VSHR

production functions in this madel are Cobb-Douglas. Similarly, the VSHR notation in the bottom center of the table sets the specification for the conswamption functions. In this case the specification is simply a share of income (value share). Finally, the IDIST symbols indicat $c$ an income distribution specification to describe the percentage of labor's income which is passed along to rural and urban bo-useholds and similarly for capital's income.

The specification table reflects some of the power of the HERCULES system. Under previous methods of modeling, changing the production functions from Cobb-Douglas to Constant Elasticity of Substitution involved many hours of tedious and demanding work. With the HERCULES system one simply changes $C D$ to CES in the spectification table and makes a few adjustments to parameter inputs.

Once the SAM and the specification table are defined they are loaded into the Cell Table. This is done with the two parameter statements shown below.

\section{ALIAS (ACC,ACCP)}

PARAMEIER CT CELL TABLE;

CT(ACC,ACCP,"TBASE") = SAM(ACC,ACCP);

CT $(A C C, A C C P, " S P E C=")=\operatorname{SPEC}(A C C, A C C P)$;

The ALIAS command is used to create an additional version of the set of accounts, ACC, as ACCP (accounts prime). Then the parameter statements are used to load sirst the SAM and then the specification table SPEC into the Cel ITable, CT. TBASE is the name of the plane in the cell table which houses the SAM and 
APP. 4A A SAM STYLE GENERAL EQUIUBAIUM MODEL 91

SPECS is the name of the plane that holds the specification table.

Next the model is defined with the model statement shown below. The model is given a name (MODELA) and a description (INITIAL DEMONSTRATION MODEL) in the first line. The second line then indicates the component parts of the model,

MODEL MODELA INTTIAL DEMONSTRATION MODEL / ACC, AT, CT/;

namely the accounts list ACC, the account table AT, and the cell table CT.

Finally, the model is solved with the SOLVE statement as shown below. This statement informs GAMS that the

SOLVE MODELA USING HERCULES;

DISPLAY AT, CT;

HERCULES solver is to be used to solve the model. Then the DISPLAY statement is used to show the results. The results are provided as additional columns in the account table AT and the cell table CT 80 it is sufficient to display these elements in order to see the results.

HERCULES, and for that matter most general equilibrium models are comparative statics models. This means that the models have no distributed lags, i.e. they are single period models. Also it means that they are used by (1) solving the model, (2) changing an exogenous variable or parameter and (3) solving the model again to permit an analysis of the effects of the change. For example, (1) the model at hand would be solved, (2) the capital stock, which is one of the exogenous variables, could be increased and (3) the model would be solved again in order to analyze the effects of capital accumulation on prices, production and consumption.

A change of an exogenous variable can be made in the model with the following statement:

$$
\text { AT("CAPITAL","QFIX") = 1.1*AT("CAPITAL","QSOL"); }
$$

Here the quantity solution, QSOL, of the CAPITAL element of the account table AT is multiplied by 1.1 in order to increase the capital stocks by ten percent as the fixed quantity input, QFIX, for the next solution. The model is then solved again and the 
92 ECONOMY-WIDE MODELS

results displayed again. This results in a decrease in the price of capital and an increase in the price (wage) of labor. Also, since food is produced primarily with labor its price increases somewhat.

The complete HERCULES model statement for the simple model follows.

STITLE MODELA: NTILAL DEMONSTRATION MODEL

- THE FOLLOWING MODEL IS THE INITIAL MODEL IN DRUD

- AND KENDRICK: "HERCULES - A SYSTEM FOR LARGE

- ECONOMYWIDE MODELS ${ }^{n}$. IT DESCRIBES A SIMPLE MODEL

- WITH TWO PRODUCTION SECTORS, TWO FACTORS OF

- PRODUCTION, AND TWO HOUSEHOLDS.

SET ACC ACCOUNTS /

LABOR

CAPITAL

HHLD-RURAL

HHLD-URBAN

FOOD

CLOTHING /;

ALIAS (ACC,ACCP);

ACRONYMS

MF MARKET FACTOR ACCOUNT

INSTC INSTITUTIONS CONSUMPTION ACCOUNT

AC ACTIVTTY OR COMMODITY ACCOUNT

Q QUANTITY FIXED

NP PRICE FIXED AS A NUMERAIRE

CD COBB DOUGLAS PROD FUNCTION SPEC

IDIST INCOME DISTRIBUTION SPECIFICATION

VSHR FIXED VALUE SHARE CONSUMPTION SYSTEM; 
APP. $4 A$ A SAM STYLE GENERAL EOUIUBRIUM MODEL O3 TABLE SAM(ACC,ACC) SOCIAL ACCOUNTING MATRIX

LABOR

LABOR CAPTAL HHLDRURAL HHL DURBAN FOOD CLOTHINO CAPITAL

HHLD-RURAL $90 \quad 30$

HHIDURBAN $70 \quad 80$

FOOD

60

$50 \quad 60$

CLOTHING

60

65

TABLE SPEC(ACC,ACC) SPECIFICATIONS TABLE

LABOR

LABOR CAPTTAL HHLD-RURAL HHLD-URBAN FOOD CLOTHINO

LABOR
CAPITAL

HHLD-RURAL IDIST MIST

HHIDURBAN IDIST IDIST

FOOD

CLOTHING

VSHR

\section{- DEFINE CELL ARRAY}

PARAMETER CT(ACC,ACC,

CT(ACC,ACCP, TBASE" $)=$ SAM(ACC,ACCP);

$\operatorname{CT}\left(A C C, A C C P,{ }^{n} S P E C S^{n}\right)=\operatorname{SPEC}(A C C, A C C P)$;

TABLE AT(ACC,") ACCOUNT TABLE

TYPE FIX

$\begin{array}{ll}\text { LABOR } & \text { MF } \\ \text { CAPITAL } & \text { MF }\end{array}$

HHLD-RURAL INSTC

HHLD-URBAN INSTC

FOOD

$A C$

$\begin{array}{ll}\mathrm{CD} & \mathrm{CD} \\ \mathrm{CD} & \mathrm{CD}\end{array}$

CLOTHING AC 
94 ECONOMY-WIDE MODELS

MODEL MODELA INITIAL DEMONSTRATION MODEL

/ACC, AT, CT/;

DISPLAY "ACCOUNT AND CELL TABLES BEFORE SOLVE:", AT,CT;

SOLVE MODELA USING HERCULES;

DISPLAY "ACCOUNT AND CELL TABLE AFTER FIRST SOLVE:", $A T, C T$;

- EXPERIMENT INFORMATTON:

- CHANGE THE QUANTITY OF CAPITAL BY A FACTOR 1.1 FROM

- THE base VALUE.

AT("CAPITAL","QFIX") = 1.1*AT("CAPTAL","QSOL");

SOLVE MODELA USING HERCULES;

DISPLAY "ACCT AND CELL TABLES AFTER SECOND SOLVE:", $A T, C T$;

In summary, a small model with three institutions can be used to study price and income distribution effects. A more complicated model which includes intemational trade is discussed in the following section.

\section{A Trade Model}

The following paragraph is also contained in the body of Chapter 4 as an introduction to the trade model. It is reproduced here to smooth the introduction to the trade model here in the Appendix.

The key element of the trade model is the separation of the commodity accounts into 4 groups as is shown in Figure 4A.1. 


\section{ECONOMY-WIDE MODELS}

ity accounts. There is an agriculture (food) and industrial (clothing) account for each of the four types of commodity accounts. The last account is the rest-of-the-world account. This account receives payments from consumption accounts for imports and provides payments to producing accounts for exports.

Portions of the SAM for this general equilibrium model with trade are shown in Table 4A.5. The bottom right-hand comer of the top portion of the table shows that importers pay 50 to the rest of the world for agricultural imports and 100 for industrial imports.

Table 4A.5 A Portion of the SAM for a Trade Model

+ COM-DOM-AG COM-DOM-IN COM-DMP-AG COM-DMP-IN $\begin{array}{lr}\text { INDR-TAX } & 20 \\ \text { ACT-AGRCLT } & 140\end{array}$ ACT-INDSTR 10 20

+ COM-CMP-AG COM-CMP-IN COM-EXP-AG COM-EXP-IN REST-WORLD

SAVING-INV

INDR-TAX

ACT-AGRCLT

ACT-INDSTR

15

5

20

COM-DOM-AG 160

COM-DOM-IN

COM-IMP-AG 70

COM-IMP-IN

COM-EXP-AG

60

50

195

120

COM-EXP-IN

In contrast, the last column in the bottom part of the table shows that the rest of the world pays 75 to exporters of agricultural goods and 55 to exporters of industrial goods. So the country in this model exports more food than it imports (75 as opposed to 50) and imports more clothing that it exports (100 as opposed to 55). Overall, imports are 150 and exports are 130 with the difference being made up by a foreign capital inflow of 20 which is provided from the rest-of-the-world to the savings-investment account.

A portion of the specification table for the trade model is shown in Table 4A.6. The 'IMPORT specifications in the 
APP. 4A A SAM STYLE GENERAL EQUILBRIUM MODEL 95

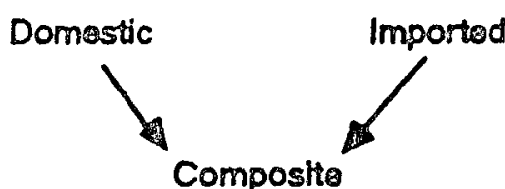

Exportad

Figure 4A.1 Types of Commodities

As expected there are imported and exported commodities. Also, there are domestically produced commodities. The new element is the composite commodities which are blends of domestic and imported goods. The essential notion is that within a given sector, say clothing, the domestic good and the imported good are not identical but can be viewed as substitutes for one another. Therefore, the model treats domestic and imported goods as inputs to the production of a composite good. There is substitution between the domestic and imported goods depending on their relative prices. Total domestic consumption can then be measured as the demand for the composite good. Exports on the other hand stand alone and compete with other goods on the world market.

This treatment of commodities is reflected in the list of accounts for the trade model in Table 4A.4. Not all the accounts are included, rather only those which are new in this model.

Table 4A.4 A Portion of the SAM for a Trade Model

SET ACC ACCOUNTS/

\begin{tabular}{|c|c|}
\hline SAVING-INV & SAVINGS AND INVESTMENTS \\
\hline & DOMESTIC COMM IN AGR \\
\hline COM-DOM-DN & DOMESTIC COMM IN INDUSTRY \\
\hline COM-IMP-AG & IMPORTED COMM IN AGRICULTURE \\
\hline OOM-IMP-IN & IMPORTED COMMODITES IN INDUSTRY \\
\hline COM-CMP-AG & COMPOSTIE COMM IN AGRICULTURE \\
\hline COM-CMP-IN & COMPOSITE COMMODIIIES IN INDUSTRY \\
\hline COM-EXP.AG & EXPORTED COMM IN AGRICULTURE \\
\hline COM-EXP-IN & EXPORTED COMMODITIES IN INDUSTRY \\
\hline REST- & REST OF THE WORLD ACCOUNT / \\
\hline
\end{tabular}

The first new account is savings-investment. While this account plays a number of roles in the model, its main role in the international trade portion of the model is to receive foreign loans and investment. The next eight accounts are all commod- 
APP. 4A A SAM STYLE GENERAL EQUILIBRIUM MODEL \$7

Table 4A.6 A Portion of the Specification Table for a Trade Model

+ COM-DOM-AG COM-DOM-IN COM-IMP-AG COM-IMP-IN

INDR-TAX TIAX TIX TAX ITAX

ACT-AGRCLT IO

ACT-INDSTR

IO

REST-WORID

10

IMPORT IMPORT

+ COM-CMP-AG DOM-CMP-IN COM-EXP-AO COM-EXP-IN REST.WORLD

SAVING-INV

INDR-TAX

ACT-AGRCLT

ACT-INDSTR

COM-DOM-AG CES

COM-DOM-IN

COM-IMP-AG

COM-IMP-IN

COM-EXP-AG

COM-EXP-IN
UNSPEC

ITAX $\quad \operatorname{TAX}$

Bo

10

CES

EXPORT

EXPORT

REST-WORLD row indicates that COM-IMP-AG and COMIMP-IN are both imported commodities. There is a sale tax on these goods as indicated by the 'ITAX' specification; however, there is no import duty. The HERCULES system includes specifications for both import duties and export subsidies; however they are not included in this model. In the bottom hall of the table the 'EXPORT specification in the rest-of-the-world column indicates that COM-EXP-AG and COM-EXP-IN are eXported commodities. The 'UNSPEC' specification in the savings-investment row indicates that there is not a particular specification for this entry.

The 'CES' specifications in the composite commodity columns are used to show that domestic and imported commodities are combined in the constant elasticity of substitution form to create the composite commodity which is consumed. Thus if the relative price of imported and domestic goods change there will be a substitution of the one for the other in meeting consumption requirements. The elasticities of substitution for these functions are given in the SIGMA column of Table 4A.7 which shows a portion of the Account Table for this model. The 
Table 4A.7 A Portion of the Account Table for a Trade Model

TABLE AT(ACC, *) ACCOUNT TABLE

$\begin{array}{lccc} & \text { TYPE } & \text { FIX } & \text { SIGMA } \\ \text { COM-DOM-AG } & \text { AC } & & \\ \text { COM-DOM-IN } & \text { AC } & & \\ \text { COM-IMP-AG } & \text { AC } & & \\ \text { COM-IMP-IN } & \text { AC } & & 3.0 \\ \text { COM-CMP-AG } & \text { AC } & & 0.5 \\ \text { COM-CMP-IN } & \text { AC } & & \\ \text { COM-EXP-AG } & \text { AC } & & \\ \text { COM-EXP-IN } & \text { AC } & & \\ \text { REST-WORLD } & \text { ROW } & \text { NP } & \end{array}$

specification indicates that domestic and imported foods are more easily substituted for one another with a sigma of 3.0 than are domestic and imported clothing with a sigma of only 0.5 .

The rest of the Account Table shows that all of the commodity accounts are treated like sectors since they are assigned the type 'AC. Also the REST-WORLD account is given a new instirutional designation as 'ROW. Finally, the numeriare in this model is the price of foreign exchange since the RESTWORLD account is designated with NP.

The price elasticity of the intemational demand for exports is specified in a different way with the use of the set and assignment statements shown below. First a set of exported commodities is created with the SET ACCEX statement. Then

\section{SET ACCEX(ACC) EXPORTED COMM /COM-EXP-AG, COM-EXP-IN/}

PARAMETER ETAS(ACCEX) ELAS OF DEMAND FOR EXP / COM-EXP-AG $=3.0, C O M-E X P-I N=1.5 /$

the elasticities for these two commodities are given as 3.0 for food and 1.5 for clothing.

The complete HERCULES statement of the trade model follows. 
APP. 4 A A SAM STME GENERAL EQUIUBRIUM MODEL 99

STITLE MODEL WITH FOREIGN TRADE, INVEST, AND SAVINGS SSTTTLE DEFINITION OF ACCOUNT SET AND ACRONYMS

- THE FOLLOWING MODEL IS DESCRIBED IN THE CHAPTER ON

- FOREIGN TRADE, INVESTMENT, AND SAVINGS IN DRUD AND

* KENDRICK: "HERCULES - A SYSTEM FOR LARGE

- ECONOMYWTDE MODELS".

SET ACC ACCOUNTS/

LABOR

CAPITAL

LABOR

HOUSEHLD-C HOUSEHOLD CONSUMPTION ACCOUNT

GOVERNMT-I GOVERNMENT INCOME ACCOUNT

GOVERNMT-C GOVERNMENT EXPEND ACCOUNT

SAVING-INV SAVINGS AND INVESTMENTS

INDR-TAX

INDIRECT TAX ACOOUNT

VAL-ADD-AG VALUE ADDED IN AGRICULTURE

VALADD-IN VALUE ADDED IN INDUSTRY

ACT-AGRCLT PRODUCTION ACTIVTTY FOR AGRI

ACT-INDSTR PRODUCTION ACTIVITY FOR INDUSTRY

COM-DOM-AG DOMESTIC OOMMODITIES IN AGR

COM-DOM-IN DOMESTIC COMMODITIES IN INDUS

COM-MP-AG IMPORTED COMMODITIES IN AGRI

COM-MMP-IN INPORTED COMMODITIES IN INDUS

COM-CMP-AG COMPOSITE COMMODITIES IN AGRI

COM-CMP-IN OOMPOSITE COMMODITIES IN INDUS

COM-EXP-AG EXPORTED COMMODITIES IN AGR

COM-EXP-IN EXPORTED COMMODITIES IN INDUS

REST-WORLD

REST OF THE WORLD ACCOUNT /

ALIAS (ACC,ACCP);

ACRONYMS

MF

INST

INSTC

TAX

AC

ROW

MARKET FACTOR ACCOUNT

INSTITUTIONS INCOME ACCOUNT

INSTITUTIONS CONSUMPTION ACCOUNT

INDIRECT TAX ACOOUNT

ACTIVTTY-COMMODITY ACCOUNT

REST OF THE WORLD ACCOUNT

NP PRICE EXOGENOUS - NUMERAIRE

$Q \quad$ QUANITIY EXOGENOUS 
100 ECONOMY-WIDE MODELS

$\begin{array}{ll}\text { CD } & \text { COBB-DOUGLAS PRODUCTION FUNCTION } \\ \text { CES } & \text { CES PRODUCTION FUNCTION } \\ \text { EXPORT } & \text { EXPORT DEM FROM REST OF WORLD } \\ \text { IDIST } & \text { INCOME DISTRIBUTION SPECIFICATION } \\ \text { IMPORT } & \text { PAYMENTS FOR IMPORTS } \\ \text { IO } & \text { INPUT-OUTPUT SPECIFICATION } \\ \text { ITAX } & \text { INDIRECT TAX SPECIFICATION } \\ \text { QEXO } & \text { FIXED QUANTITY CONSUMPTION SYS } \\ \text { QSHR } & \text { FXXED QUANTITY SHARE CONS SYS } \\ \text { UNSPEC } & \text { UNSPECIFIED OR RESIDUAL } \\ \text { VEXO } & \text { SPECIFICATION FOR EXOGENOUS VALUE } \\ \text { VSHR } & \text { VALUE SHARE CONSUMPTION SYSTEM }\end{array}$

\$STTILE DEFINITION OF SOCIAL ACCOUNTING MATRKX

TABIE SAM(ACC,ACC) "SAM WITH TRADE, INVEST, AND SAV"

LABOR CAPITAL HOUSEHLDI HOUSEHLD-C HOUSEHLD-I HOUSEHLDC GOVERNMT-I SAVING-INV COM-CMP-AG COM-CMP-IN

$$
\begin{aligned}
& 20 \\
& 40
\end{aligned}
$$
GOVERNMT-I COVERNMT-C SAVING-INV INDR-TAX GOVERNMT-I GOVERNMT-C SAVING-INV COM-CMP-AG COM-CMP-IN
70
40

$\begin{array}{ll}15 & 15 \\ 55 & 85\end{array}$

\begin{tabular}{|c|c|c|c|c|}
\hline \multicolumn{5}{|c|}{ L-ADD-IN ACT-AGRCLT ACT-INDSTR } \\
\hline LABOR & 95 & 65 & & \\
\hline CAPITAL & 30 & 80 & & \\
\hline VAL-ADD-AG & & & 125 & \\
\hline VALAADD-IN & & & & 145 \\
\hline COM-CMP-AG & & & 40 & 30 \\
\hline COM-CMP-IN & & & 35 & 60 \\
\hline COM-D & OM-AG & COM-DOM-IN & COM-IMP-AG & COM-IMP-IN \\
\hline INDR-TAX & 20 & 10 & 20 & 20 \\
\hline ACT-AGRCLT & 140 & & & \\
\hline ACT-INDSTR & & 185 & & \\
\hline REST-WORLD & & & 50 & 100 \\
\hline
\end{tabular}


APP. 4A A SAM STYLE GENERAL EQUIUBRIUM MODEL 101 COM-CMP.

INDR-TAX

ACT-AGRCLT

ACT-INDSTR

COM-DOM-AG 160

COM-DOM-IN

COM-IMP-AG 70

COM-IMP-IN

COM-EXP-AG

COM-EXP.IN

\$STITLE DEFINITION OF SPECIFICATION AND CELL TABLES

TABLE SPEC(ACC,ACC) SPECIFICATION TABLE

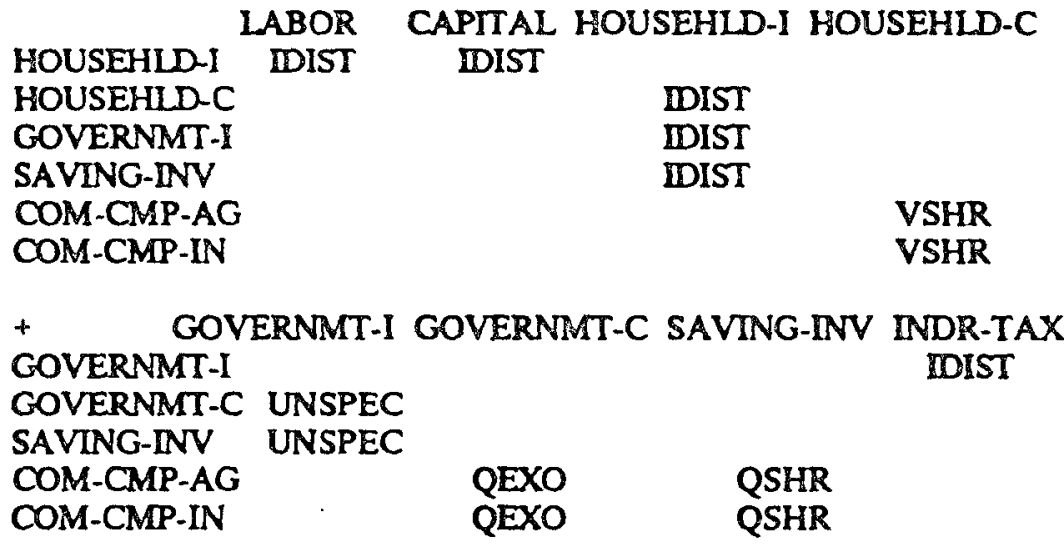

$+\quad$ VAL-ADD-AG VAL-ADD-IN ACT-AGRCLT ACT-INDSTR LABOR CD CD

CAPITAL CD CD

VAL-ADD-AG

VALADDIN

COM-CMP-AG

COM-CMP-IN

10

10

$\begin{array}{ll}10 & 10 \\ 10 & 10\end{array}$

+ COM-DOM-AG COM-DOM-IN COM-IMP-AG COM-IMP-IN INDR-TAX ITAX ITAX ITAX ITAX

ACT-AGRCLT IO

ACT-INDSTR

10

REST-WORID

MPORT IMPORT 
102 ECONOMY-WIDE MODELS$$
+
$$
COM-CMP-AG COM-CMP-IN COM-EXP-AG COM-EXP-IN INDR-TAX ACT-AGRCLT

ACT-INDSTR

COM-DOM-AG CES

COM-DOM-IN

COM-MMP-AG CES

COM-IMP-IN

ITAX

TAX

10

10

SAVING-INV

COM-EXP-AC

DOM-EXP-IN

\author{
REST-WORLD \\ UNSPEC \\ EXPORT \\ EXPORT
}

SET ACCEX(ACC) EXPORTED COMM

/COM-EXP-AG,COM-EXP-IN

PARAMETER ETAS(ACCEX) ELAS OF DEM FOR EXPORTS / COM-EXP-AG $=3.0$, COM-EXP-IN $=1.5 /$

- DEFINE AND FILL THE CELL TABLE:

PARAMETER CT(ACC,ACC,") CELL TABLE;

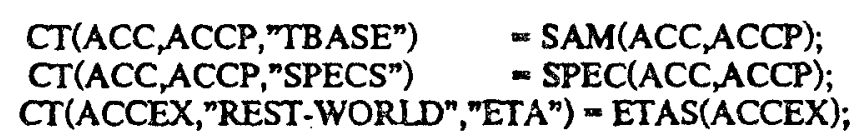


APP. IA A SAM STME GENERAL EOUILIBRIUM MODEL 103 SSTITLE ACCOUNT TABLE AND ACCOUNT TOTALS

TABLE AT(ACC,*) ACCOUNT TABLE

\begin{tabular}{|c|c|c|c|}
\hline & TYPE & FIX & SIGM \\
\hline LABOR MF & 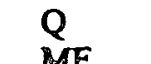 & & \\
\hline $\begin{array}{l}\text { CAPITAL } \\
\text { HOUSEHLD-I }\end{array}$ & $\begin{array}{l}\text { MF } \\
\text { INST }\end{array}$ & $Q$ & \\
\hline HOUSEHLD-C & INSTC & & \\
\hline GOVERNMT-I & INST & & \\
\hline GOVERNMT-C & INSTC & & \\
\hline SAVING-INV & INSTC & $\mathbf{Q}$ & \\
\hline INDR-TAX & TAX & & \\
\hline VAL-ADD-AG & AC & & \\
\hline VAL-ADD-IN & AC & & \\
\hline ACT-AGRCLT & AC & & \\
\hline ACT-INDSTR & AC & & \\
\hline COM-DOM-AG & AC & & \\
\hline COM-DOM-IN & $A C$ & & \\
\hline COM-MMP-AG & AC & & \\
\hline COM-IMP-IN & $A C$ & & \\
\hline COM-CMP-AG & AC & & 3.0 \\
\hline COM-CMP-IN & AC & & 0.5 \\
\hline COM-EXP-AG & $A C$ & & \\
\hline COM-EXP-IN & $A C$ & & \\
\hline REST-WORID & RoW & NP & \\
\hline
\end{tabular}

PARAMETER TOTALS(ACC,") ACCT TOT AND IMBAL SAM;

TOTALS(ACC,"ROW-TOTAL") = SUM(ACCP,SAM(ACC,ACCP));

TOTALS(ACCP,"COL-TOTAL") = SUM(ACC,SAM(ACC,ACCP));

TOTALS(ACC,"DIFFERENCE") = TOTALS(ACC,"ROW-TOTAL")TOTALS(ACC, "COL TOTAL");

DISPLAY "CHECK FOR BALANCE OF BASE SAM:",TOTALS;

\$STITLE MODEL DEFINITION, EXPER SOLUTION AND REPORT

MODEL MODELD "MODEL WITH TRADE, INVEST, AND SAV" / ACC, AT, CT/; 
104 ECONOMY-WIDE MODELS

- DEFINE SETS AND PARAMETERS FOR REPORT TABLES THAT

- SUMMARIZE ALL EXPERIMENTS AND DEFINE THE BASE CASE.

SET COM(ACC) "DOM, IMP, COMP, AND EXXPORTED COMM"

/ COM-DOM-AG, COM-DOM-IN, COM-IMP-AG, COM-IMP-IN,

COM-CMP-AG, COM-CMP-IN, COM-EXP-AG, COM-EXP-IN/;

PARAMETER

REPORTQ(COM,*) QUANTTIIES OF ALL COMMODITIES

REPORTP(COM,*) PRICES OF ALL COMMODITIES;

- REPORT -BASE CASE-

REPORTQ(COM,"BASE-CASE") = TOTALS(COM,"COL-TOTAL"); REPORTP(COM, "BASE-CASE") $=1$;

* experdment data: changes in worlo prices

- WORID AGRICULTURAL PRICES ARE INCREASED BY 10\% AND

- WORLD INDUSTRIAL PRICES ARE DECREASED BY $10 \%$.

CT("REST-WORLD", "COM-IMP-AG","WP") $=1.1$;

CT("REST-WORLD","COM-IMP-IN","WP") =0.9;

CT( ${ }^{n}$ COM-EXP-AGn, "REST-WORLD" ${ }^{n}$ WP $\left.^{n}\right)=1.1$

CT("COM-EXP-IN","REST-WORID", "WP") $=0.9$;

SOLVE MODELD USING HERCULES;

DISPLAY "ACCT AND CELL INFO AFTER SOLV BASE MODEL:", AT, CT;

- REPORT - SOLUTION BASE MODEL:

REPORTO(COM, "BASE-SOLUT" $=$ AT(COM, "OSOL");

REPORTP(COM, "BASE-SOLUT") = AT(COM," "PSOL");

- DEFINE AND SOLVE AN ALTERNATTVE MODEL WTTH

- AGRICULNURAL EXPORT ELASTICITY INFINITY

- NOTE THAT WORLD PRICES ARE STILL 10\% HIGHER FOR

- AGRICULTURAL GOODS AND 10\% LOWER FOR INDUSTRIAL

- GOODS.

CT("COM-EXP-AG","REST-WORLD", "ETA") = INF; 
APP. 4A A SAM STME GENERAL EQUILIBRIUM MODEL 105 SOLVE MODELD USING HERCULES;

DISPLAY "ACCT AND CELL INFO AFTER ETA-AG=INF EXPER :", AT, CT;

- REPORT - SOLUTION TO MODEL 2: REPORTQ(COM,"ETA-AG=-INF") = AT(COM, $\left.{ }^{n} Q S O{ }^{n}\right)$; REPORTP(COM,"ETA-AG=INF") = AT(COM,"PSOL");

- BEFORE SOLVING THE NEXT MODEL, RESTORE THE INPUT

- part of the cELl table to ITS original CONTENT

- AGAIN, I.E. RESET THE EXPORT ELASTICTIIES TO THEIR BASE

- VALUES:

CT(ACCEX,"REST-WORLD","ETA") = ETAS(ACCEX);

- DEFINE AND SOLVE AN ALTERNATIVE MODEL WTTH

- AGRICULTURAL IMPORT ELASTICTTY INFINTTY.

AT("COM-CMP-AG","SIGMA") = INF;

SOLVE MODELD USING HERCULES;

DISPLAY "ACCT AND CELL INFO AFTER SGM-AG=INF EXPER :", AT,CT;

- REPORT - SOLUTION TO MODEL 3:

REPORTQ(COM,"SGM-AG=INF") = AT(COM,"QSOL"); REPORTP(COM,"SGM-AG=INF") = AT(COM,"PSOL");

- DisPlay SUMMARY TABLES

DISPLAY REPORTQ, REPORTP; 


\section{Appendix AB \\ A Johansen Style General Equilibrium Model}

This appendix contains the linearized version of a small general equilibrium model which is drawn from Kendrick (1984) which is in tum based on Dixon (1979) and Dixon, Parmenter, Sutton, and Vincent (1982). The mathematical statement is given first followed by a GAMS statement of the model which can be used as a computer input file. For a discussion of the parameters and the results from solving this small model see Kendrick (1984).

\section{The Model in Rates of Change}

The tilde over a variable indicates that it is the rate of change of the variable. Thus $c^{n}$ is the level of nominal consumption and $c^{n}$ is the rate of growth of nominal consumption.

Demand Equations

(i) demand for domestic and imported goods

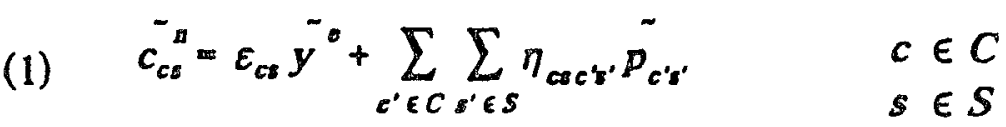

where

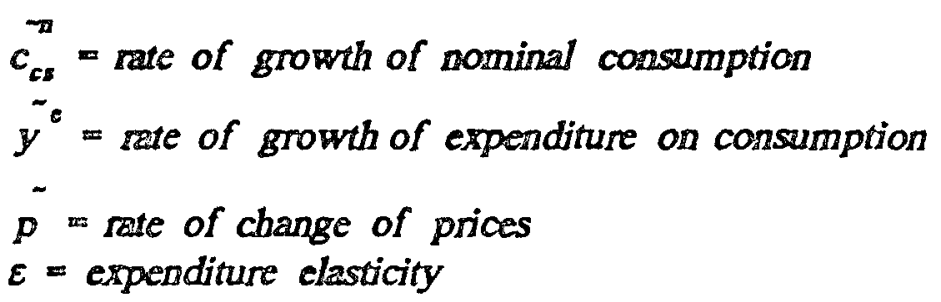


APP. AB A JOHANSEN STME GENERAL EOUILIBRIUM MODEL 107

$\eta=$ cross price elasticities

$S=$ \{domestic , imported $\}$

(ii) demand by foreigners for domestic goods

(2)

$$
\begin{array}{ll}
\tilde{p}_{c}^{c}=-\gamma_{c} \tilde{e}+\tilde{d_{c}^{f}} & c \in C \\
& s \in S D
\end{array}
$$

where

$\tilde{p_{c}}=$ rate of change of export price for commodity $c$

$e^{-}=$rate of change of exports

$\tilde{d}_{c}^{t}=$ shift factor in demand for exports

Production Functions

(i) supply response equations

(3) $\quad \tilde{q_{d}}=\tilde{z_{i}}+\left(\tilde{p_{c s}} \cdot \sum_{c^{\prime} \in C} r_{c^{\prime} l} \tilde{p_{c^{\prime} s}}\right) \quad \begin{aligned} & c \in C \\ & \\ & j \in S D \\ & j \in I\end{aligned}$

where

$\tilde{q}_{d}=$ rate of growth of production of commodity $c$ in industry $i$

$\bar{z}_{i}=$ rafe of growth of production activity in incustry $i$

$r_{c}=$ share of revenue from commodity $c$ in incustry $i$

$S D=\{$ domestic $\}$ 
108 ECONOMY-WDE MODELS

(ii) production functions

input demand function for commodities

(4)

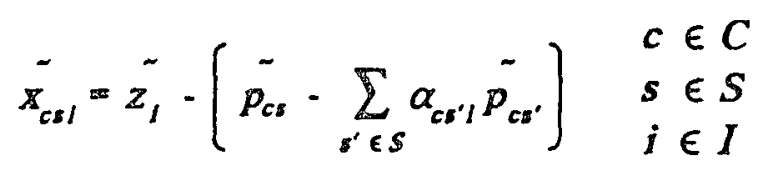

where

$\tilde{x_{c s i}}=$ rate of growth of intermediate input $c$ from source $s$ into inchustry $i$

$\alpha_{c s i}$ share of expenditure by industry

input demand function for capital

(5)

$$
\tilde{k_{1}}=\tilde{z_{1}} \cdot\left(\tilde{p_{1}}-\alpha_{1}^{\alpha} \tilde{w}-\alpha_{1}^{p} \tilde{p}_{1}^{\tilde{k}}\right) \quad i \in I
$$

where

$k_{1}=$ rate of growth of capital stock in industry $i$

$\alpha_{1}^{\prime}=$ share of expenditure on labor

$w$ = rate of growth of wages

$\alpha_{1}^{k}$ - share of expenditure on capital

$\tilde{p}_{1}=$ rate of growth of the price of capital

input demand function for labor

(6)

$$
\tilde{I}=\tilde{z_{1}} \cdot\left(\tilde{w}-\alpha_{i}^{i}-\alpha_{i}^{k} \tilde{p}_{i}^{-}\right) \quad i \in I
$$

where

$\tilde{I}=$ rate of growth of labor in industry $i$ 
APP. 4B A JOHANSEN STME GENERAL EQUILIBRIUM MODEL 109 Price Equations

(i) commodities

(7) $\sum_{c \in C} r_{d} \tilde{p_{c s}}=\sum_{c \in C} \sum_{s^{\prime} \in s} s_{c s^{\prime} l}^{c} \tilde{p_{c s^{\prime}}}+s_{i}^{+} \tilde{p_{i}^{k}}+\tilde{s}_{i}^{\prime} \tilde{W} \quad \begin{aligned} & s \in S D \\ & i \in I\end{aligned}$

where

$$
\begin{aligned}
& s_{c s i}^{c}=\text { cost share for commodity cs } \\
& s_{1}^{k}=\text { cost share for capital } \\
& s_{1}^{l}=\text { cost share for labor }
\end{aligned}
$$

(ii) exports

(8)

$$
\begin{array}{ll}
\tilde{p_{c s}}=\tilde{p_{c}^{e}}+\tilde{v_{c}}+\tilde{\phi} & s \in S D \\
& c \in C
\end{array}
$$

where

$\tilde{p}_{c}=$ rate of change of the expon price of commodity $c$ $v_{c}=$ rate of change of one plus the ad valorem rate of export subsidy for commodity $c$

$\bar{\phi}=$ rate of change of the exchange rate

(iii) imports

(9)

$$
\begin{aligned}
& \tilde{p}_{c s}=\tilde{p}_{c}+\tilde{t_{c}}+\tilde{\phi} \\
& s \in S F \\
& c \in C
\end{aligned}
$$

where

$\tilde{p_{c}}=$ rate of change of the import price of commadity $c$ $t_{c}=$ rate of change of one plus the ad valorem tariff rate $S F=\{$ imported $\}$ 
110 ECONOMY-WDE MODELS

\section{Market Clearing Equations}

(i) commodities

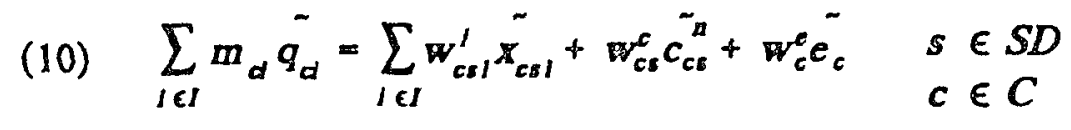

where

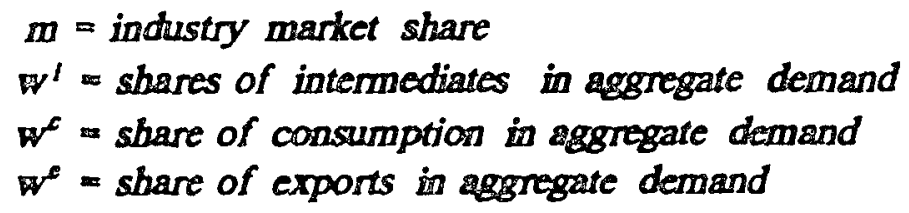

(ii) labor

(11)

$$
\sum_{I \in I} w_{i}^{i} I_{i}^{-}=I^{-T}
$$

where

$I^{\tau}$ m rate of growth of labor force

$w_{i}^{\prime}=$ share of total employment in incustry $i$

(iii) capital

$$
\hat{k}_{1}=\tilde{x}_{1} \quad i \in I
$$

where

$\tilde{k}_{1}=$ rate of growth of exrogenous capital stock for industry $i$

Miscellanoous Identities

(i) total imports

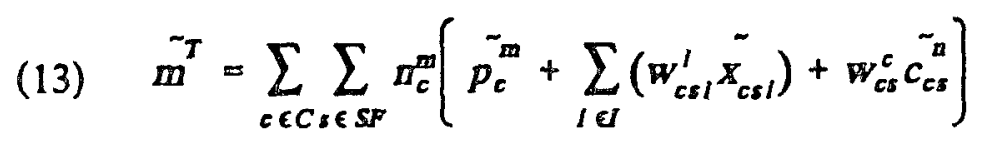

where 
APP. $4 B$ A JOHANSEN STYLE GENERAL EOUILIBAIUM MODEL 111

$$
\begin{aligned}
& \tilde{m}^{T}=\text { rate of growth of imports } \\
& n_{c}^{m}=\text { share of commodity } c \text { in toral imports }
\end{aligned}
$$

(ii) total exports

(14)

$$
e^{T}=\sum_{c \in C} n_{c}^{x}\left(\tilde{p_{c}^{e}}+\tilde{e_{c}}\right)
$$

where

$$
\begin{aligned}
& e^{T}=\text { sate of growth of exports } \\
& m_{c}^{x}=\text { shane of commodity } c \text { in total exports }
\end{aligned}
$$

(iii) balance of trade

$$
\tilde{b}=(1 / 100)\left(e^{T} e^{-T} \cdot m^{T} \tilde{m}^{T}\right) \tilde{p}^{-c}+\tilde{w^{s}}
$$

where

$$
\bar{b}=\text { rate of change of the balance of trade }
$$

(iv) consumer price index

$$
\tilde{p}^{\tilde{c}}=\sum_{c \in C} \sum_{s \in S} \mu_{c s} \tilde{P_{c s}}
$$

where

$\tilde{p}=$ rate of change of the consumer price index

$\mu_{c s}=$ share of goods cs in tatal household consumption

(v) wage rate

$$
\tilde{w}=\theta \bar{p}^{c}+\tilde{w}
$$

where

$\theta$ = wage indexiation parameter

$\tilde{W}=$ rate of change of the wage shiff factor 
112 ECONOMY-MDE MODELS

(vi) real consumption

(18)

$$
\tilde{c} \tilde{c}^{c}=\tilde{y}^{c}
$$

where

$$
c^{t}=\text { sate of change of real consumption }
$$

\section{The Model in Computer Input Form}

The following computer input is taken from the ORANI model in the GAMS Library which is available with the GAMS system software, Brooke, Kendrick, and Mecraus (1988). The format and style have been modified slightly to suit the purpose of the exposition in this book.

\$TITLE A MINIATURE VERSION OF ORANI 78

* THIS MINI VERSION OF ORANI, A MULTISECTOR PRICE

* ENDOGENOUS MODEL OF AUSTRALIA, DEMONSTRATES THE

- PERCENTAGE CHANGE FORMULATION OF JOHANSEN.

- REFERENCE: KENDRICK D, STYLE IN MULTISECTOR

- MODELING, IN A. J. HUGHES-HALLET (ED), APPLIED DECISON

- ANALYSIS AND ECONOMIC BEHAVIOR, MARTINUS NIJHOFF

- PUBLISHERS, DORDRECHT, THE NETHERLANDS, 1984

SETS

$\begin{array}{lll}\text { C } & \text { COMMODITES } & \text { /FOOD, CLOTHING/ } \\ \text { CA(C) } & \text { AGRI COMM } & \text { /FOOD/ } \\ \text { CM(C) } & \text { MANUF COMM } & \text { /CLOTHING / } \\ \text { F } & \text { FACTORS } & \text { /LABOR, CAPITAL/ } \\ H & \text { HOUSEHOLDS } & \text { /FAMIIES / } \\ \text { I } & \text { INDUSTRIES } & \text { /AGRIC AGRICULTURE, } \\ \text { S } & \text { SOURCES } & \text { / DANUF MANUFACT/ } \\ & & \text { MOMOSTIC, }\end{array}$

ALIAS $(C, C P),(S, S P),(I, I P) ; C E(C, C)=$ YES ; DISPLAY CE; 
APP. AB A JOHANSEN STME GENERAL EQUILIBRIUM MODEL 113

TABLE AMC $(C, S, ")$ ACCOUNTING MATRIX FOR COMM

$\begin{array}{lrcccc}\text { INDUSTRIES HOUSEHOLDS } & \text { EXPORTS } & \text { IMPORT } \\ \text { AGRIC MANUF } & \text { FAMILIES } & \text { EXP } & \text { DUTY } \\ \text { FOOD.DOMESTIC } & 10 & 8 & 17 & 19 & \\ \text { CLOTHING.DOMESTI } & 15 & 1 & 34 & 1 & \\ \text { FOOD.MMPORTED } & 1 & 8 & 1 & & -1 \\ \text { CLOTHING.IMPORTED 5 } & 2 & 10 & & -5\end{array}$

TABLE AMF(F,I) ACCOUNTING MATRX FOR FACTORS

$\begin{array}{lcc} & \text { AGRIC } & \text { MANUF } \\ \text { LABOR } & 20 & 20 \\ \text { CAPITAL } & 10 & 5\end{array}$

TABLE AMQ(C,I) ACCOUNTING MATRIX FOR OUTPUTS

$\begin{array}{lcc} & \text { AGRIC } & \text { MANUF } \\ \text { FOOD } & 45 & 9 \\ \text { CLOTHING } & 16 & 35\end{array}$

TABLE EPSILON(C,S) DNCOME ELASTICTTIES

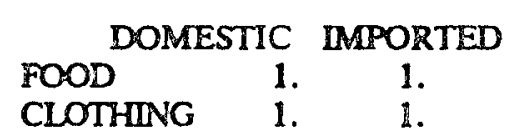


114 ECONOMY-WIDE MODELS

PARAMETERS

ALPHA $(C, S, \mathbb{1})$ SHARE OF EXP BY INDUSTRY

ALPHAK(I) SHARE OF EXPENDITURE ON CAPTTAL

ALPHAL(I) SHARE OF EXPENDTTURE ON LABOR

ALPHAE(C,S) SHARE OF GOOD CS IN EXP ON COMM C ETABAR(C,S,CP,SP) COMPENSATED PRICE ELAST

$S B(C, S)$ SHARE OF GOOD CS IN HOUSE BUDGET

ETA(C,S,CP,SP) UNCOMPENSATED PRICE ELASTICITIES ELEVEL BASE PERIOD EXP LEVEL - NOT A RATE

M(C,I) INDUSTRY MARKET SHARE

MLEVEL BASE PERIOD IMP LEVEL - NOT A RATE

$\operatorname{ALPHA}(C, S, I)=\operatorname{AMC}(C, S, I) / S U M(S P, A M C(C, S P, I))$;

ALPHAK(I) $=$ AMF("CAPITAL",I)/SUM(F, AMF(F, I));

ALPHAL(I) - AMF("LABOR",IVSUM(F, AMF(F,I));

ALPHAE $(C, S)=A M C(C, S$, "FAMILIES" $)$

SUM(SP, AMC(C,SP,"FAMLIES"));

$\operatorname{ETABAR}(C, S, C P, S P)=\operatorname{ALPHAE}(C P, S P)$

$\operatorname{ETABAR}(C, S, C, S)=-1 .+\operatorname{ALPHAE}(\mathrm{C}, S)$

$\operatorname{ETABAR}(C, S, C P, S P) \$($ NOT $C E(C, C P))=0$.

$\mathrm{SB}(\mathrm{C}, \mathrm{S})=\mathrm{AMC}(\mathrm{C}, \mathrm{S}$, ,FAMILIES")

/ SUM((CP,SP), AMC(CP,SP, "FAMILIES")) ;

$\operatorname{ETA}(C, S, C P, S P)=-\operatorname{EPSILON}(C, S)^{*} \mathrm{SB}(C P, S P)+$

ETABAR(C,S,CP,SP) ;

ELEVEL = SUM((C,S), AMC(C,S, $\left.\left.{ }^{n} E X P^{n}\right)\right)$;

$\mathbb{M}(C, I)=A M O(C, I) / S U M(I P, A M O(C, I P))$

MLEVEL = SUM(C, AMC(C, "MMPORTED", "TOTAL"));

PARAMETERS

MU(C,S)

NM(C)

NX(C)

$\mathrm{R}(\mathrm{C}, \mathrm{I})$

SC(C,S,I)

SK(I)

SL(I)

WC(C,S)

WE(C)

WEIGHTS FOR CPI

SHARE IN TOTAL MMPORTS

SHARE IN TOTAL EXPORTS

REVENUE SHARE

COST SHARE

COST SHARE FOR CAPITAL

COST SHARE FOR LABOR

WI $(C, S, I)$

SHARE OF CONSUMPTION IN DEMAND

SHARE OF EXPORTS IN DEMAND

SHARE OF INTERMEDIATES IN DEMAND ; 
APP. AB A JOHANSEN STYLE GENERAL EQUILIBRIUM MODEL 115

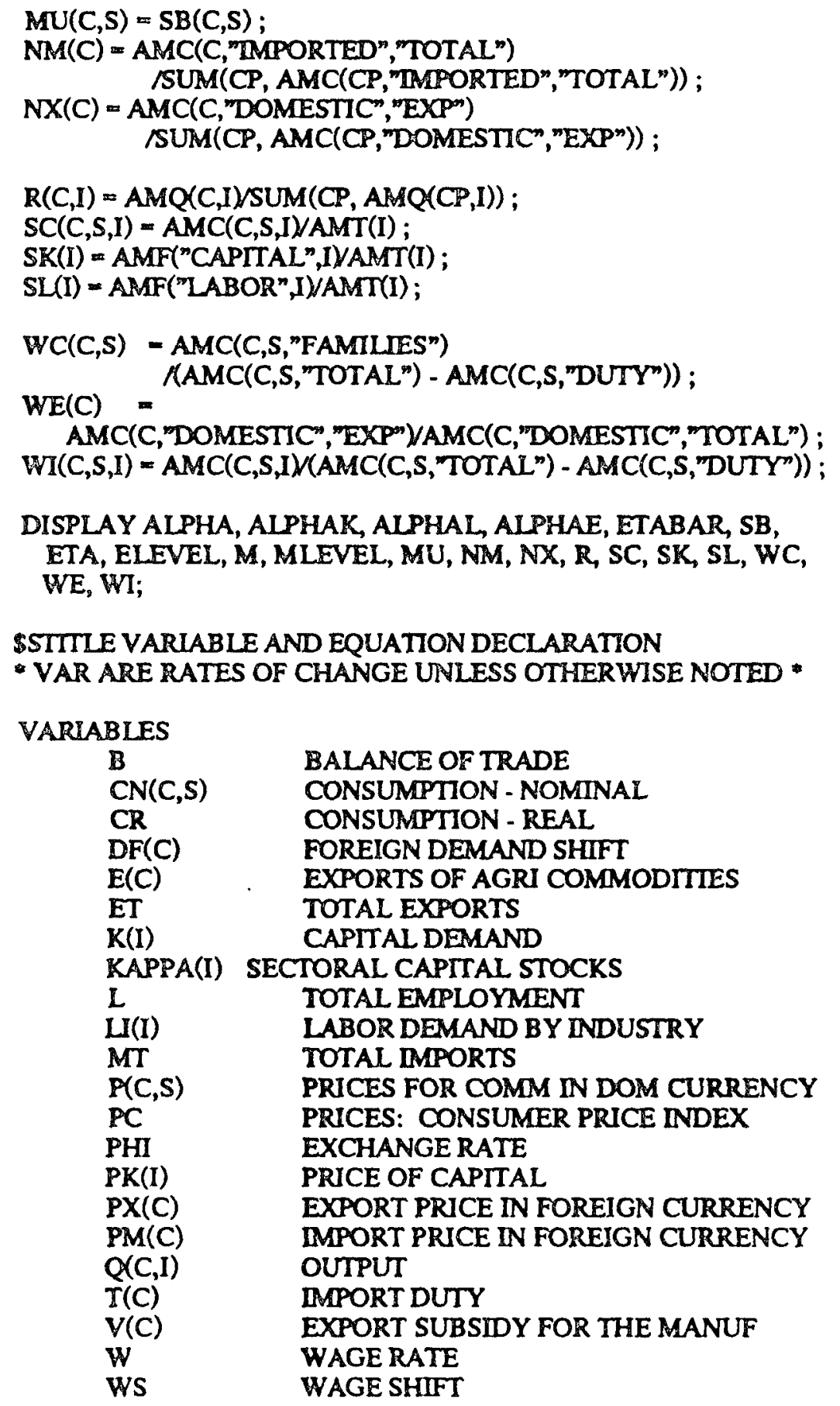


116 ECONOMY-WIDE MODELS

$\begin{array}{ll}X(C, S, I) & \text { INTERMEDIATE COMMODITY DEMANDS } \\ \text { YE } & \text { HOUSEHOLD EXPENDITRE } \\ Z(I) & \text { INDUSTRY ACTIVTY LEVEL }\end{array}$

$\begin{array}{ll}\text { EQUATIONS } & \\ \text { CON(C,S) } & \text { CONSUMPTION } \\ \text { EXPD(C) } & \text { EXPORT DEMANDS } \\ \text { SUPPLY(C,I) } & \text { SUPPLY RELATIONS } \\ \text { DNDC(C,S,I) } & \text { INPUT DEMAND FOR COMMODITIES } \\ \text { INDCAP(I) } & \text { INPUT DEMAND FOR CAPITAL } \\ \text { INDLAB(I) } & \text { INPUT DEMAND FOR LABOR } \\ \text { PRIC(I) } & \text { PRICE EQUATIONS FOR COMMODITIES } \\ \text { PRIEXP(C) } & \text { PRICE EQUATIONS FOR EXPORTS } \\ \text { PRIMP(C) } & \text { PRICE EQUATIONS FOR DMPORTS } \\ \text { BALD(C) } & \text { BALANCE EQ FOR DOMESTIC COMM } \\ \text { BALLAB } & \text { BALANCE EQUATION FOR LABOR } \\ \text { BALCAP(I) } & \text { BALANCE EQUATION FOR CAPTAL } \\ \text { IMPORTS } & \text { DMPORTS } \\ \text { EXPORTS } & \text { EXPORTS } \\ \text { BALTRADE } & \text { BALANCE OF TRADE } \\ \text { CPI } & \text { CONSUMER PRICE INDEX } \\ \text { WAGE } & \text { WAGE RATE } \\ \text { REALC } & \text { REAL CONSUMPTION } \\ \text { DUMMY } & \text { NONBIND CONS TO GET NONZERO RHS ; }\end{array}$

\$STITLE EQUATION DEFINITIONS

$\operatorname{CON}(C, S) . . \quad$ CN $(C, S)=E=\operatorname{EPSILON}(C, S) * Y E+$ SUM ((CP,SP),ETA(C,S,CP,SP)*P(CP,SP)) ;

$\operatorname{EXPD}(C) . \quad P X(C)=E=-G A M M A(C)=E(C)+D F(C)$;

$\operatorname{SUPPLY}(C, I) . . Q(C, I)=E=Z(I)+\left(P\left(C,{ }^{D D O M E S T I C}\right)\right.$ - SUM(CP, R(CP,I)*P(CP,"DOMESTIC"))) );

$\operatorname{INDC}(C, S, I) . . X(C, S, I)=E=Z(I)-(P(C, S)$

- SUM(SP, ALPHA(C,SP,I) P(C,SP))) ;

INDCAP(I).. $\quad K(I)=E=Z(I)-(P K(I)-A L P H A L(I) * W$

- ALPHAK(I)*PK(I));

$\operatorname{INDLAB}(\mathrm{I}) . . \quad \mathrm{L}(\mathrm{I})=\mathrm{E}=\mathrm{Z}(\mathrm{I})-\left(\mathrm{W}-\mathrm{ALPHAL}(\mathrm{I})^{*} \mathrm{~W}-\right.$

ALPHAK(I)*PK(I)); 
APP. 48 A JOHANSEN STYLE GENERAL EQUILIBAIUM MODEL 117

PRIC(I).. $\quad \operatorname{SUM}\left(C, R(C, I)^{*} P\left(C,{ }^{2}\right.\right.$ DOMESTIC")) $\approx E=$ $\operatorname{SUM}((\mathrm{C}, \mathrm{SP}), \mathrm{SC}(\mathrm{C}, \mathrm{SP}, \mathrm{I}) * \mathrm{P}(\mathrm{C}, \mathrm{SP}))$

$+\mathrm{SK}(\mathrm{I})^{*} \mathrm{PK}(\mathrm{I})+\mathrm{SL}(\mathrm{I})^{*} \mathrm{~W}$;

PRIEXP(C).. P(C,"DOMESTIC") $=E=P X(C)+V(C)+P H I$;

PRIMP(C). . P(C,"IMPORTED") $=E=P M(C)+T(C)+P H I$;

$B A L D(C) . \quad \quad \operatorname{SUM}(1, M(C, I) \cdot Q(C, I))=E=$

SUM(I, WI(C,"DOMESTIC",I)*X(C,"DOMESTIC",I))

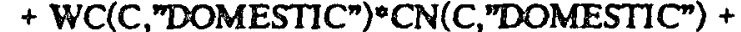
$W E(C)^{\wedge} E(C)$;

BALLAB.. $\quad S U M\left(I, W L(I)^{*} L(I)\right)=E=L$;

BALCAP(I).. $\quad K(I)=E=K A P P A(I)$;

IMPORTS.. $\quad M T=E=\operatorname{SUM}(C, \operatorname{NM}(C) *(P M(C)+$

SUM(I, WI(C,"IMPORTED",I)*X(C,"MMPORTED,$I))$

+ WC(C,"'MMPORTED")*CN(C,"IMPORTED $\left.\left.{ }^{n}\right)\right)$ );

EXPORTS.. ET $=E=\operatorname{SUM}\left(C, N X(C)^{*} P X(C)+N X(C) * E(C)\right)$;

BALTRADE. $\quad B=E=($ ELEVEL ET - MLEVEL"MT $) / 100$;

CPI.. $\quad P C=E \approx S U M((C, S), M U(C, S) * P(C, S))$;

WAGE.. $\quad W=E=$ THETA*PC + WS ;

REALC. $\quad C R=E=Y E-P C$;

DUMMY.. $\quad P C=\mathrm{L}=100000$;

SSTITLE EXOGENOUS VARIABLES AND SOLUTION REPORTS

$\operatorname{DF} . F X(C)=1 ; E . F X(C M)=1 ; \operatorname{KAPPA} . F X(I)=3 ; \operatorname{PHI} . F X=0 ; \operatorname{PM} . F X(C)=-2$; T.FX(C)=0; V.FX(CA)=0; WS.FX $=0$; YE.FX $=2$;

MODEL ORANI /ALL;

SOLVE ORANI USING LP MINIMIZING PC; 


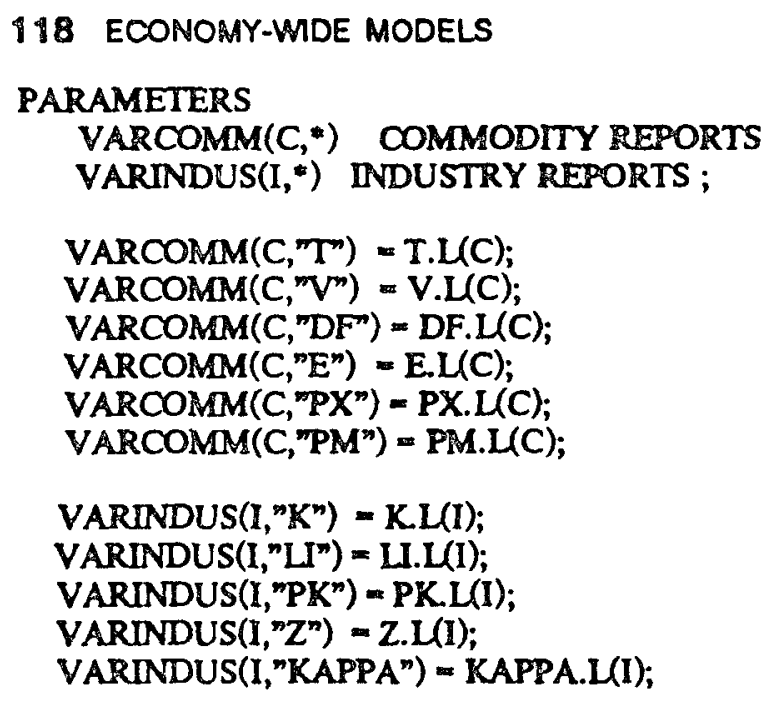

DISPLAY B.L, CR.L, ET.L, LL, MT.L, PC.L, W.L, PHI.L, WS.L YE.L, Q.L, X.L, CN.L, VARCOMM, VARINDUS; 


\section{Growth}

In a review article written almost thirty years ago Chenery (1961) contrasted the comparative advantage with the growth model approach to development policy. The comparative advantage approach was to eliminate trade barriers and use commodity and factor prices to find those goods which should be exported and those which should be imported. In some cases this strategy resulted in unbalanced growth as a country specialized in the export of a few mining and agricultural products. In other cases this strategy brought about varied and vigorous development.

In contrast, the growth model view argued for balanced growth so that there would be synergistic effects among the sectors as they exploited economies of scale behind infant industry trade barriers. Also, this view relied more on import substitution than on export promotion to fuel the growth process.

Under this dichotomy of development strategy the models of the previous chapter would be aligned with the comparative advantage view and those of the current chapter with the growth view. Indeed the historical roots of the two types of modeling can be traced to groups and countries that advocated the corresponding points of view. However, the models need not be aligned with an ideological point of view. One might use a general equilibrium model and find that the best trade strategy was one replete with trade barriers. Or a growth model might be used in an investigation that found that the removal of trade barriers provided a major stimulus for high rates of oconomic growth.

In that same review article Chenery outlined the use of linear programming models as an aid in determining development strategy. This chapter follows in that tradition by using the control theory models of Kendrick and Taylor (1970) for South Korea and Martens and Pindyck (1975) for Tunisia as examples. These models illustrate the methodology and provide a good basis for discussing the strengths and weaknesses of this class of models for determining dynamic comparative advantage. 


\section{The Kendrick and Taylor Model}

At the time that this South Korean model was developed linear programming growth models of a number of countries had been created (see Eckaus and Parikh (1968), Chakravarty and Lefeber (1965), Bruno (1966), and Manne and Weisskopf (1972)). The goal of the Kendrick and Taylor project was to show that it was feasible to solve nonlinear control theory models on the mainframe computers of the day. This racant that the models could incorporate nonlinear production and welfare functions and thus could be more realistic than the models in which these functions were linear. The project reached its goal by developing and solving a four sector, thirty time period model with constant elasticity of substitution production functions and a nonlinear welfare function on an IBM 7094 mainframe computer. Today, models similar to this can be solved on personal computers and much larger models can be solved on modern mainframe and supercomputers.

a. The Mathematical Model

The model has a nonlinear criterion function and nonlinear systems equations which are difference equations. There are five groups of equations in the model as follows:

- criterion function

- capital stock accumulation equations

- distribution and production functions

- foreign trade equations

- initial and terminal conditions

The nonlinearities in the system equations are in the investment equations and in the production functions.

\section{Criterion Function}

The nonlinear criterion function depends on the consumption $c_{j l}$ of goods from sector $j$ in time period $i$. The welfare derived from this consumption is a nonlinear function of the consumption level of the form $a c^{b}$, where $a$ and $b$ are parameters of the nonlinear welfare function. Also the welfare is discounted 
CH. 5 GROWTH 121

using the discount rate $z$. The resulting criterion function is Eq.(1) below.

(1)

$$
\begin{aligned}
& \xi=\sum_{i=1}^{N}(1+z)^{-1} \sum_{j=1}^{4} a_{j} c_{j}^{b_{j}} \quad 0 \leq b_{j} \leq 1, \quad a_{j}>0 . \\
& \text { Where } \\
& \xi=\text { criterion value } \\
& z=\text { consumption discount rate } \\
& c_{\| l}=\text { consumption of goods from sector } j \text { in period } j \\
& a, b=\text { parameters }
\end{aligned}
$$

The parameters $a$ and $b$ were chosen so that they were consistent with the the observed consumption shares and income elasticities of demand in South Korea (see Kendrick and Taylor (1969)).

\section{Capital Stock Accurnulation}

The usual capital stock accumulation equation in dynamic models specifies that the capital stock in period $i+1$ is equal to the capital stock in the previous period plus investment $\delta$ i.e.

$$
\boldsymbol{k}_{J .1+1}=k_{\mu}+\delta_{\mu}
$$$$
j \in J
$$$$
i \in I
$$

where

$$
\begin{aligned}
& k_{J 1}=\text { capital stock in sector } j \text { in time periad } i \\
& \delta_{J l}=\text { investment level in sector } j \text { in time period } i
\end{aligned}
$$

However, the use of nonlinear programming methods opens a broader range of possibilities. For example a nonlinear function like $g$ in Eq. (3) below can be used. This permits a specification in which the

(3)

$$
k_{J .1+1}=k_{J 1}+g_{J}\left(\delta_{J 1}, k_{J l}\right)
$$


effective addition to the capital stock depends on the investment input and on the existing capital stock. For example, a country with large capital stocks in a given industry could be specified as being more efficient in adding to its capital stock than another country with little or no capital stock in that industry. Also, the nonlinear function could be used to represent diminishing returns to efforts to increase the capital stock. For example, if investment equal to ten percent of the capital stock was attempted, the outcome would be an increase of eight percent in the capital stock, i.e., $4 / 5$ ths of the input would become output. However, if the investment input was fifty percent of the capital stock, the actual increase in the capital stock would be twenty percent, i.e. 2/5 ths. A function embodying this notion is graphed in Figure 5.1, where $\delta$ is the investment effort and $\delta / \mathrm{k}$ is investment as a percentage

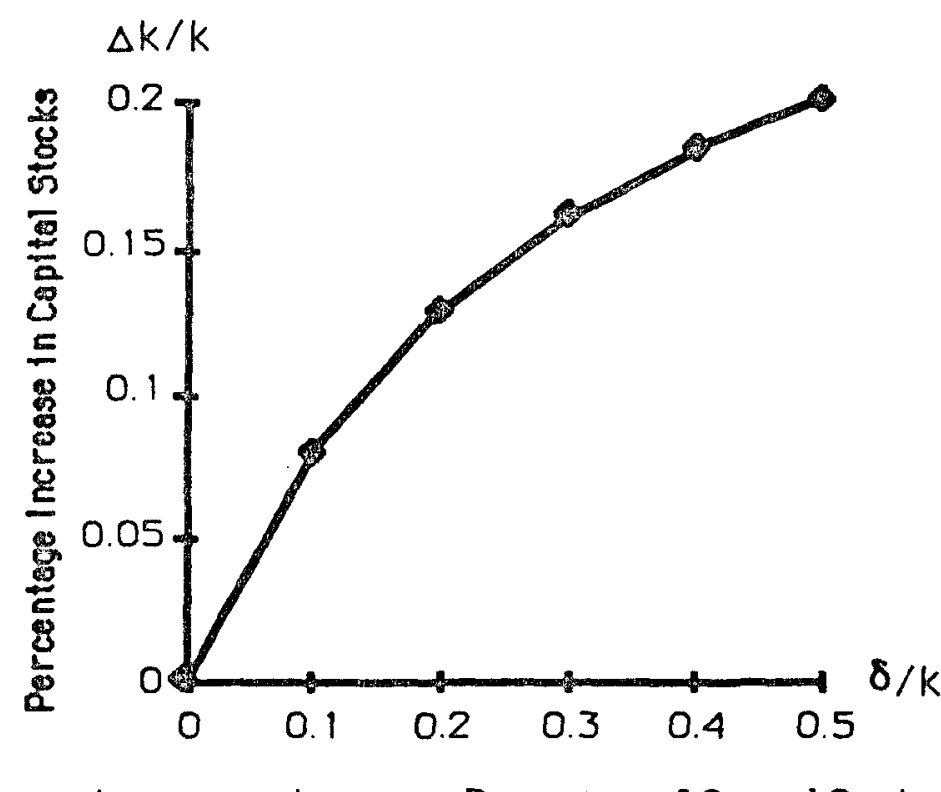

Investment Input as a Percentage of Cap ital Stock

Figure 5.1 Absorptive Capacity Function

of the capital stock, while $\Delta \mathrm{k} / \mathrm{k}$ is the resultant increase in the capital stock. The mathematics of this absorptive capacity function are given in Eq. (4). 
(4)

$$
g_{\lambda}\left(\delta_{\jmath}, k_{J I}\right)=\mu_{J} k_{J l}\left[1-\left(1+\frac{\varepsilon_{J}}{\mu_{J}} \frac{\delta_{J I}}{k_{J I}}\right)^{-1 / \varepsilon_{j}}\right] j \in J
$$

with

$$
\varepsilon, \geq-1, \mu, \geq 0
$$

The example of the function plotted in Fig. 5.1 is for $\varepsilon$ equal to 0.5 and $\mu$ equal to .275 . Changing $\varepsilon$ affects the curvature of the function and changing $\mu$ affects the asymptotic value. Thus with $\mu$ equal to .275 the greatest percentage increase possible in a single time period is 27.5 percent.

The absorptive capacity function embodies notions that are important in dynamic comparative advantage. A country may not have a comparative advantage when its capital stocks are small, but as it grows it becomes more efficient in creating new capital stocks and thus can obtain a comparative advantage over time. Also, the function includes the idea that there are diminishing retums to efforts to expand an industry rapidly. However, it may be difficult to estimate accurately the parameters of this type of function. This is so because coonomic statics frequently do not distinguish between $\delta$, the investment activity level, and $\Delta \mathrm{k}$, the effective increase in output.

\section{Distribution and Production Functions}

In all economic models it is necessary to insure that the use of each commodity does not exceed its availability. This is accomplished in the current model with Eq. (5). There are two types

$$
q_{1}+D q_{1}+m_{1}=A q_{1}+B \delta_{1}+c_{1}+c_{1} \quad i \in I
$$

where 


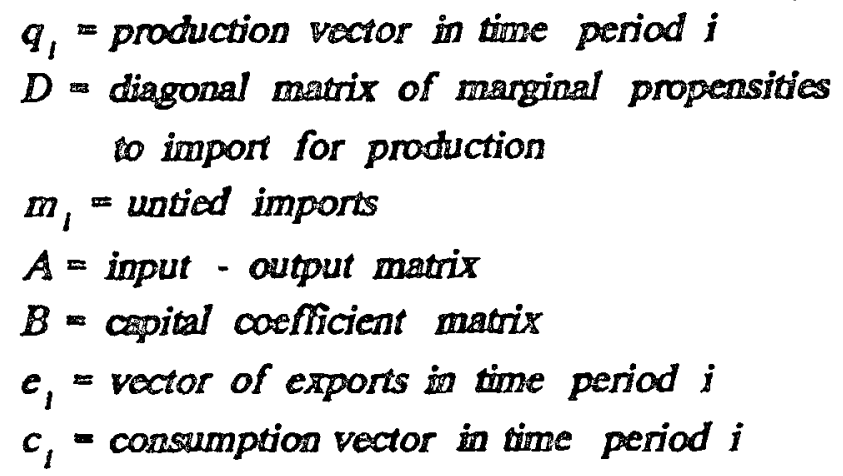

of imports on the left hand side of this equation: (1) those which are tied to production levels and (2) those which are not tied. Production plus the two kinds of imports must equal the uses of each commodity as (1) intermediate inputs, (2) investment inputs, (3) exports, and (4) consumption goods.

The production functions are of the constant elasticity of substitution (CES) form which is shown in Eq. (6). The two factor

(6) $q_{J 1}=\tau_{J}\left(1+v_{J}\right)^{\prime}\left[\beta_{J} k_{J I}^{-p_{J}}+\left(1-\beta_{J}\right) l_{J I}^{-p_{J}}\right]^{-1 / p_{J}} \quad j \in J$

where

$\tau_{1}$ efficiency jarameter

$v_{j}=$ rate of tochnical progress

$\beta$, distribution perameter

$\rho_{j}=\left(1 / \sigma_{j}\right)-1=$ elasticity of substitution parameter

$I_{j 1}=$ labor input in sector $j$ in period $i$

inputs are capital and labor and $\beta$ is the distribution parameter between the two factor inputs. Technical progress is modeled as disembodied by the parameter $v$ which is the rate of technical progress. The CES specification is useful in this type of model because it can be specialized to perfect substitutability as $\sigma$ approaches infinity or to fuxed coefficients as $\sigma$ approaches zero. 
The sum of the labor inputs to the sectors is constrained by the labor force, as is shown in Eq. (7). It is implicitly assumod here

(7)

$$
\sum_{J \in J} I_{J I}=I_{I} \quad i \in I
$$

where

\section{1 = Labor force in period $i$}

that labor is perfectly mobile across sectors, while capital is fixed in a sector once investment occurs. Much capital is indeed fixed in the industry where the investment occurs (e.g., blast furnaces and oil refineries); however, some capital can be used by various kinds of industries (e.g., vehicles and buildings). So long as all sectors grow monotonically the assumption that capital cannot move between sectors is a reasonable one, but the assumption could cause problems in a situation where some industries grow and then contract.

\section{Foneign Trade}

The foreign trade equations contain assumption about exports, imports and foreign debt. The assumptions about exports in this model are in Eq. (8), where it is assumed that exports are fixed

$$
\begin{array}{cl}
e_{J I} \text { given } & j \in J \\
& i \in I
\end{array}
$$

where

$$
c_{J I}=\text { exports from the sector } j \text { in period } i
$$

exogenously. This assumption is one of the most serious shortcomings of this model, not because exports are difficult to project (though that can be a problem), but rather because the assumption of fixed exports sets a frame of mind in which the analyst and policy makers assume that they cannot affect the export level. This is not only not true but also prevents the analyst from using one of the most important aspects of any development strategy.

The import assumptions were more realistic. As Eq. (9) shows it was assumed that there would be no untied imports of agricultural and mining products (sector 1) nor of services (sector 4) but that there could be untied imports in the heavy industry 
128 ECONOMY-WIDE MODELS

(9)

$$
m_{1 l}=m_{4 l}=0 \quad i \in I
$$

where

$$
m_{J l}=\text { imports of sector } j \text { goods in period } i
$$

(sector 2) and light industry (sector 3 ) sectors. Also, there are tied imports for production and investment which are distinguished by sector of use rather than by sector of origin, so these imports can include commodities from all four sectors. In an evolving world of international trade the assumption of no untied imports of services may also be somewhat short-sighted. For example, some years ago there was not much international trade in services, but more recently this has been growing rapidly.

The next equation is one of the most important in the model. It is the foreign debt accumulation equation. (For another example of a debt accumulation equation which play an imporatant role in a growth model see Alatorre (1981)). It says that the foreign debt in any time period will equal the debt in the previous period multiplied by one plus the interest rate plus the current account deficit. This is shown in Eq. (10). The interest rate was

$$
\begin{array}{r}
\gamma_{l+1}=(1+\theta)_{\gamma_{l}}+\sum_{j \in J}\left(d_{J} q_{J l} \cdot e_{j l}+\pi_{j} \delta_{j}+m_{J l}\right) \\
i \in I
\end{array}
$$

where

$$
\begin{aligned}
& \gamma_{I}=\text { foreign debt in period } i \\
& \theta=\text { interest rate on foreign debt } \\
& d_{J j}=\text { diagonal elements of the } D \text { matrix , i.e. }
\end{aligned}
$$

manginal propensities to import for praduction

$\pi_{1}=$ marginal propensity to import for investment

treated as a constant in the model but clearly it should be time varying. Also, the same interest rate is applied to all elements of foreign debt, whereas in fact various portions of the total debt may be borrowed at different interest rates.

This equation plays a pivotal role because most countries increase their foreign debt during the development process with an expectation of decreasing the debt later in time. An example is 
South Korea, which incurred a large debt over some years and then began to repay the debt. Also, this equation is useful to illustrate the effects of increases in world interest rates on the development process and prospects of countries which have lange foreign debts.

\section{Initial and Terminal Conditions}

Dynamic models require initial conditions which mirror the situation in the economy at the beginning of the time horizon covered by the model. Also, the models frequently contain terminal conditions which are targets. For example, the model at hand has in Eq. (11) an initial foreign debt which is given and a terminal

$$
\gamma_{1} \text { known and } \gamma_{N+1} \text { chosen as a target }
$$

foreign debt which is chosen as a target. The target may reflect a desire that the amount of foreign debt increase or contract during the time horizon covered by the model. Also, the terminal deb represents the negative part of the bequest of one generation to the next.

The positive part of the bequest is in the terminal conditions for capital stock, which are shown in Eq. (12). As with foreign

$$
k_{J 1} \text { known and } k_{J, N+1} \text { chosen as targets }
$$

debt, the initial conditions for capital stocks are given by the situation of the country, while the terminal conditions are chosen as targets.

In some growth models the terminal capital stocks are not included as constraints but rather added as an element in the criterion function. However, in all growth models some treatment of terminal capital stocks is necessary to represent the interest of future generations; otherwise there will be substantial dissavings in the last few time periods covered by the model.

\section{b. Results}

The most important results from this kind of model are investment input paths. One development strategy would use most of the investment in early years to buildup the heavy industry sector while constraining sharply the development of the light in- 
dustry sector and the production of consumption goods. An altemative strategy would send investment into the agriculture and mining industries at an carly stage in order to increase exports enough to earn the foreign exchange to buy the imported investment goods which are required to develop the heavy and light industry sectors later in time. A third strategy might emphasize exports from the light industry sector.

A second part of the results is the time path for foreign debt. If the country begins with a small foreign debt the best strategy Inay be to increase this debt at first rapidly and then more slowly over the time horizon covered by the model. Alternatively, a country may be saddled with a large debt initially and may want to develop a strategy which maintains this debt at its initial level or attempis to reduce the debt somewhat.

\section{c. Strengths and Weaknesses of the Model}

This class of models captures many of the ideas which are important in economic growth and development. The parameters of the objective function embody different income elasticities of demand for each sector. Thus, one would expect solutions to indicate that the most rapidly growing industries are those for which the income elasticity of demand is high.

Secondly, the models include the input-output structure of the economy in the A matrix as well as bringing out the fact that investment goods come in greater proportion from some sectors than from others, as indicated in the B matrix. Thus the interdependent nature of the economy is encapsulated by the model, with emphasis on the fact that capital formation will require more rapid growth of heavy industry sectors than of light industry.

Thirdly, the models contain not only untied but also tied imports. Thus investment increases in some industries require much more substantial proportions of imports than in other industries. Also, production activities in some industries require much larger amounts of imported raw and intermediate materials than other incustries. These aspects of the economy are included in the $d_{\nu}$ and $\pi$, parameters of the foreign debt accumulation equation.

Fourthly, the model has limits on labor availability but permits exogenous increases in the labor force through domestic popula- 
tion growth or through immigration. Also, substitution between labor and capital is permitted, so that the economy can grow more rapidly than the labor force through a process of capital deepening.

Fifthly, nonlinear models with four sectors and many time periods could be solved on mainframe computers in 1970 but can be solved on personal computers today. Therefore, nonlinear models with substantial sectoral disaggregation can now be solved on today's mainframe and supercomputers.

These are some of the strengths of this class of models. What are some of the shortcomings? The most glaring shortcoming is the treatment of exports as exogenous. A more desirable specification would permit unilimited exports at a fixed world price, as in come of the sectoral models, or exports with price elasticities of demand, as in some of the general equilibrium models. There is no reason in the methodology that such specifications cannot be added to the existing model structures. If the price elasticities were introduced, then the foreign exchange rate would play a role in the export and import equations and the model would be able to capture problems like those now faced by countries with large external debts. If these countries attempt to repay a substantial portion of that debt then they must decrease their exchange rates and give their currency such a low value that exports grow rapidly and imports grow slowly or even decline.

A second shortcoming is a matter of taste. The criterion function which was used in the model has nice theoretical properties and carries in its parameters information about sectoral shares and income elasticity of demand. However, this criterion has the weakness that it is difficult to explain to policy makers. When cosomists start talking about nonlinear welfare and utility functions policy makers sometimes tune out. An alternative approach is much easier to explain but does not have such nice theoretical properties. This is the quadratic tracking function which is commonly used in control theory and which was applied to a growth model of Tunisia by Martens and Pindyck (1975). That approach will be discussed in some detail later in the chepter 80 no more discussion of it will be given bere.

Another alternative criterion function for growth models is favored by some economists. This function is the discounted out put valued at world prices. The reason for using world prices is that domestic prices are sometimes distorted and world prices provide a better measure of opportunity cost. Also, if one uses this criterion then the shadow prices provide a measure of the increase in the discounted value of output which could be obtained 


\section{ECONOMY-WIDE MODELS}

from added units of any scare resource. The prices in turn could be used in models to evaluate the dynamic comparative advantage of industries. However, there is at least one shortcoming in the use of this form of criterion function. In this case the criterion function is linear in consumption, and even if the model has nonlinear production functions the model will be linear in investment activities unless an adsorptive capacity function like the one in the Kendrick and Taylor model is used. If the model is linear in investment activities then the solution will be characterized by dynamics in which investment bangs back and forth between upper and lower bounds rather then maintaining smooth growth. This result is one of the reasons why economists tend to favor nonlinear criterion functions for growth models.

A third shortcoming of this class of models is the lack of prices. Of course the shadow prices from the constraints in the model provide price results, but these are not adequate. In the first place the shadow prices are the partial derivatives of the criterion function value with respect to the right band side element of a constraint. Thus, if the criterion were the gross national product of a country and one of the constraints was a labor force constraint like Eq. (7) above, then the shadow price would indicate the increase in GNP which could be expected for each additional worker in the labor force and thus would be a good extimate of the annual wage. However, most criterion functions in growth models are not gross national product but rather welfare functions like the one defined above, and the units of these functions are not as meaningful as the national currency in the gross national product. Moreover, the criterion functions frequently contain a variety of elements like terminal capital stock terms, employment or income distribution measures. Then the interpretation of the shadow prices as prices is more strained or just plain misleading.

Also, prices and wages in an economy are usually a result of many institutional and political as well as economic forces and shadow prices do not capture these phenomena well. Therefore, if prices and wages are to be added to growth models they should follow in the tradition of the equations in econometric models in which today's prices or wages will be the same as the last periods, with increases or decreases reflecting demand and supply conditions in the cconomy. Alternatively, general cquilibrium submociels might be used in each time period in growth models to colve for supply and demand pressures and thus to provide indi- 
cations of the direction and amount of price and wage changes in each time period.

The addition of price and wage equations to growth models would lay the foundations for inclusion of income distribution information in the models along the lines of the methods used in general equilibrium models.

Present day computable general equilibrium models are strong on price and wage results and have the structure to permit careful analysis of the income distribution effects of policies. However, as was discussed earlier, these models are weak on dynamics, investment, and growth. Therefore future models may evolve which either add investment and growth to general equilibrium models or which add prices, wages, and income distribution to growth models.

Another shortcoming of growth models is the lack of ability to include economies of scale. The basic problem is that growth models with diseconomies of scale provide global optimal solutions while models with economies of scale can provide only local optimality.

An alternative approach is to use linear mixed integer programming methods which search over all the local optima in an attempt to find the global optimum. This is the approach which was taken by Westphal (1971) in his model of South Korea. However, this approach requires that the rest of the model be linear or linearized so that linear rather than nonlinear mixed integer programming methods can be used.

\section{The Martens and Pindyck Model}

One of the major shortcomings of the Kendrick and Taylor model is the use of the general nonlinear criterion function. This kind of function is attractive to most economists since it has nice theoretical properties; however, it is difficult to convey its meaning to policy makers. Nonlinear welfare functions are intriguing to economists but are rather ephemeral objects to politicians.

One alternative to general nonlinear welfare functions is quadratic-linear tracking criterion functions. With these functions the decision maker chooses desired paths for the economy. For example, the decision maker may have a preference for slow growth in light consumption goods and very rapid growth in ex- 
porting industries in the near term, followed by rapid growth in heavy industry in the intermediate term and then by rapid growth in light consumer goods toward the end of the planning horizon. These paths need not be consistent with one another, they need only represent what the politician wants.

Thus, if the criterion function had only a single variable it would have the form of minimizing

$$
J=\sum_{t a}\left(x_{t}-\bar{x}_{t}\right)^{2}
$$

where

$$
\begin{aligned}
& J=\text { criterion value } \\
& x_{t}=\text { value of a variable the } t \\
& \tilde{x}_{t}=\text { desired value of the variable at ime } t
\end{aligned}
$$

The criterion is called a quadratic tracking function because the variable $x_{t}$ should track the desired path, $\hat{x}_{t}$, in order to minimize the value of the criterion. If the criterion has two variables, say $x_{1 t}$ and $x_{2 t}$ it is recessary to assign penalty weights to the two terms as follows:

$$
J=\sum_{t \in T}\left\{w_{1}\left(x_{1 t}-\bar{x}_{1 t}\right)^{2}+w_{2}\left(x_{2 t}-\bar{x}_{2 t}\right)^{2}\right\}
$$

where

$$
\begin{aligned}
& x_{n}=\text { value of variable i in period } t \\
& \tilde{x}_{t}=\text { desired value for variable in period } t \\
& w_{1}=\text { penalty weight for variable } f
\end{aligned}
$$

The choice of a large penalty weight for one variable relative to the other would indicate that a higher priority was given to having that variable follow its desired path. For example, the decision makers might feel that it was more important to follow closely the desired path for exports than the desired path for production of light consumer goods. In this case a high priority (weight) would be assigned to exports.

It is common to write Eq. (14) in vector matrix form as 


$$
\text { where } \begin{aligned}
J & =\frac{1}{2} \sum_{i \in T}\left\{\left(x_{t}-\tilde{x}_{t}\right)^{\prime} W\left(x_{t}-\hat{x}_{t}\right)\right\} \\
x_{t} & =\text { vector of state variables } \\
\dot{x}_{t} & =\text { vector of desired state variables } \\
W & =\text { diagonal matris of peralty weights }
\end{aligned}
$$

Here $x_{t}$ is called a vector of state variable to distinguish it from a vector of control variables, $u_{t}$. The state variables are used to describe the state of the economy: for example, capital stock and output variables are typical state variables. The control variables are policy instruments like sectoral investment.

There are also desired paths and weights for the control variable, so the criterion function is written as

(16)

$$
J=\frac{1}{2} \sum_{t \in T}\left\{\left(x_{t}-\hat{x_{t}}\right)^{\prime} W\left(x_{t}-\hat{x_{t}}\right)+\left(u_{t}-\hat{u_{t}}\right)^{\prime} R\left(u_{t}-\hat{u_{t}}\right)\right\}
$$

where

$$
\begin{aligned}
& J=\text { criterion value } \\
& \hat{x}=\text { vecior of desired values of state variables } \\
& \hat{u}=\text { vector of desired values of control variables } \\
& W=\text { diagonal matrix of penalities for state variables } \\
& R=\text { diagonal matrix of penalties for control variables }
\end{aligned}
$$

Thus, assigning high penaity weights to the diagonal elements of $W$ relative to the weights in $R$ gives high priority to having the state variables follow their desired paths without showing much concern for the paths traversed by the control variables.

In a policy setting Eq. (16) is used in an interactive way. The policy maker chooses desired paths and priorities for the state and control variables. The economist then solves the model and reports the solution $x^{\bullet}$ and $u^{\bullet}$ back to the decision maker. New desired paths $\bar{x}$ and $\vec{u}$ and weights $W$ and $R$ are chosen and 
the process is repeated until the policy maker is satisfied with the outcome. Thus it is not necessary for the policy maker to know exactly what penalty weights to use, but rather only to be able to know which results he or she prefers. So while the decision

maker is asked to choose $\hat{x}_{t}, \hat{u_{t}}, W$, and $R$ the iterative process means that he or she only need have a clear idea of preferences with regard to the $x_{t}^{p}$ and $u_{i}^{p}$ solutions to the model.

The criterion is used along with the systems equations to provide a complete quadratic-linear tracking problem. The systems equations contain the model and must be either linear or linearized difference equations of the form

$$
x_{t+1}=\overline{A x}_{t}+\tilde{B u}_{t}+\tilde{c} \quad t \in T
$$

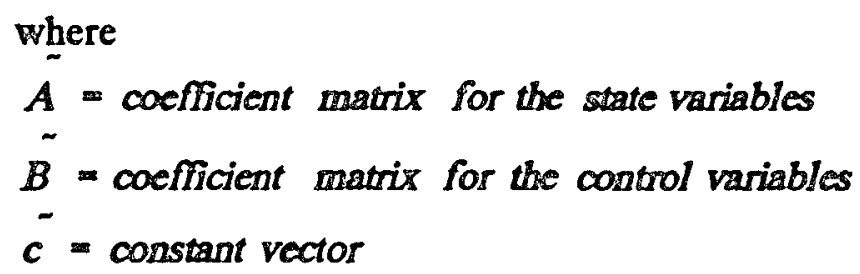

with initial conditions

$$
x_{0}=\text { given initial state vector }
$$

The dynamic equations come from the model. For example in the Martens and Pindyck (1975) model some of the systems equations come from the accumulation equations for output and investment

$$
q_{t+1}=q_{t}+G i_{t} \quad t \in T
$$

where

$$
\begin{aligned}
& q_{t}=\text { vector of sectoral output level } \\
& G=\text { diagonal matrix of output - capital ratios } \\
& i_{t}=\text { vector of sectoral investment levels }
\end{aligned}
$$


These equations specify that the output level in each sector will be the same as in the previous year plus the increase in output which can be produced from the new investment in each sector. Comparing Eqs. (17) to (19) shows that if these were the only equations in the model the state vector would be the output levels of the sectors and the control vector would be the investment levels in those sectors. Also, the parameter definitions would be

$$
\begin{aligned}
& \tilde{A}=I \quad \text { the identity matrix } \\
& \tilde{B}=G \\
& \tilde{C}=0
\end{aligned}
$$

However, the accumulation equations are not the only equations in the model. In fact the Martens and Pindyck model has about forty equations. Not all those equations will be discussed here. Rather, a simplified version of the Martens and Pindyck model which captures most of the key concepts of that model will be presented.

The essential idea of the model is that goods are produced which can be used either for consumption or investment. If they are used for investment they add to future capacity and permit greater production in future time periods, as illustrated in Eq. (19) above. If they are used for consumption they add to immediate satisfaction. Also, there are exports and imports in the model. Goods allocated to exports decrease the goods which are available for consumption or investment but they eam foreign exchange. The foreign exchange can then be used to buy imported capital goods, intermediate materials, or consumption goods.

The state and control vectors for the simplified model are

$$
z=\left[\begin{array}{c}
\eta \\
\psi \\
\lambda \\
q_{1} \\
q_{2} \\
\vdots \\
q_{n}
\end{array}\right]
$$




$$
u=\left[\begin{array}{l}
j_{1} \\
i_{2} \\
\vdots \\
i_{m}
\end{array}\right]
$$

whe re

$$
\begin{aligned}
& m=\text { gross national product } \\
& \eta=\text { balance of payments } \\
& .1=\text { employment } \\
& -\eta_{N}=\text { output from sector } j \\
& . i_{10}=\text { investment in sector } j
\end{aligned}
$$

Consistency is formed on the model by the materials balance constraints which wieshowa below

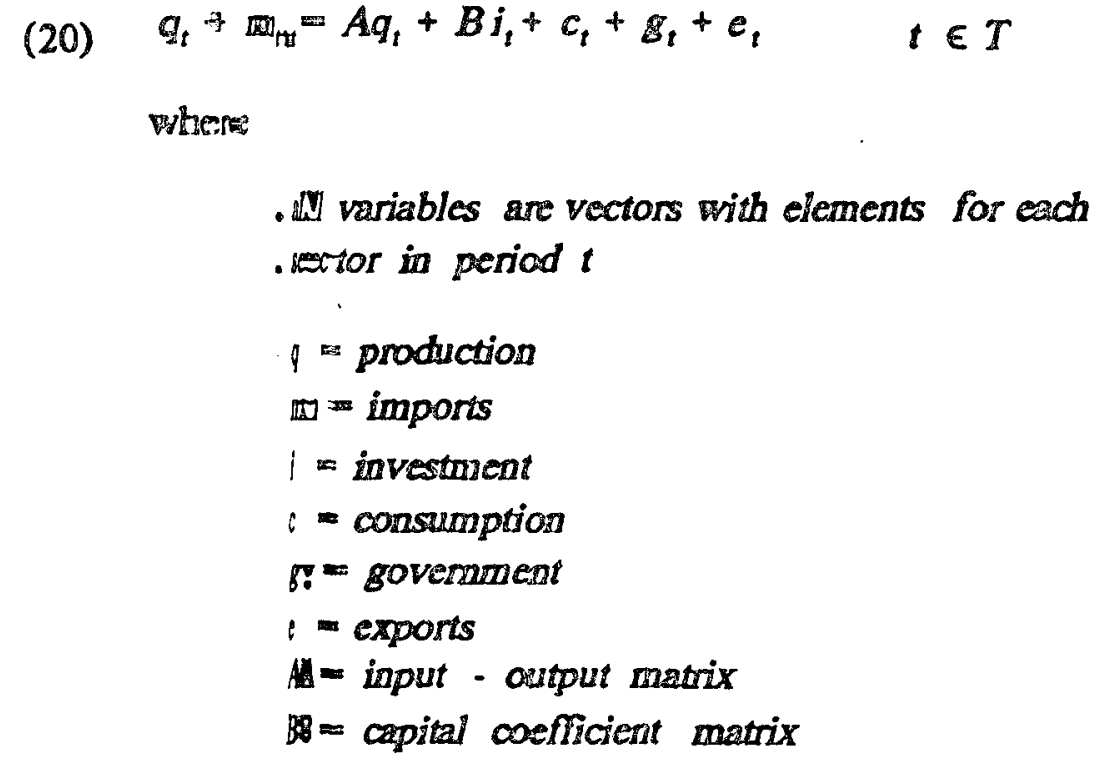

Eq. (20) remiliser that the country can use no more than it produces and imports. Iltre goods can be used for intermediate inputs, invesiment, conusurmption, govemment, and exports. 
Consumption adjusts over time from present levels as disposable income rises or falls, as indicat ad

$$
c_{t+1}=N c_{t}+a \omega_{t+1} \quad t \in T
$$

where

$N=$ diagonal matrix of coefficientor for lagged consumption a vector of coefficients for disponciable income

$\omega=$ dispasable income (a scalar)

As output grows additional labo im ust be employed.

$$
\lambda_{t+1}=\lambda_{t}+\Gamma\left(q_{t+1} \cdot g_{t}\right) \quad t \in T
$$

where

$$
\begin{aligned}
& \lambda=\text { Labor : employnenat } \\
& I \text { - vector of sectoral labor - output ratios }
\end{aligned}
$$

Eq. (22) indicates one of the differences between the two models discussed in this chapter. The Kemetiel and Taylor model contains a labor force constraint which must be satisfied. In contrast the Martens and Pindyck model treats lotal employment as a state variable which should follow a desimed path. If the actual path diverges too much from the desired pathiin a given solution then it is necessary to increase the penalty weighal for that state variable and to solve the model again.

The balance of payments equation is the sum of imports minus exports plus foreign capital inflow, 250 sthown below. 


$$
\psi=\sum_{J \in J} m_{J}-\sum_{J \in J} e_{j}+\phi
$$

where

$$
\begin{aligned}
& \psi=\text { balance of payments } \\
& \phi=\text { foreign capital inflow }
\end{aligned}
$$

There is no foreign debt accumulation equation in this model, but one could easily be added.

Exports are ireated as exogenous in this model.

Mathematically, this means that they are are part of the $c$ vector in Eq. (17) while economically, this means that this models suffers from the same shortcomings in international trade as does the Kendrick and Taylor model.

Disposable income is defined as one minus the income tax rate times gross national income. The full Martens and Pindyck

$$
\omega_{t}=(1-\tau) \eta_{8}
$$

$t \in T$

where

$$
\begin{aligned}
& \eta=\text { national income } \\
& \tau=\text { income tax rate }
\end{aligned}
$$

model includes both direct and indirect taxes; however in this as in many other aspects the model is simplified here to provide an introduction. The interested reader is encouraged to read the original article.

Finally, the gross national product in this model is defined as equal to the value of output minus the value of intermediate inputs. 


$$
\eta_{t}=1^{\prime}(I \cdot A) q_{t}
$$

where

$$
\begin{aligned}
& I^{\prime}=\text { vector of ones } \\
& I=\text { identity matrix }
\end{aligned}
$$

In summary the quadratic tracking criterion function from the Martens and Pindyck model can be used to cure one of the major shortcomings of the Kendrick and Taylor model by providing a criterion function which can be basis for interaction between economists and politicians.

This completes a review of the strengths and weaknesses of the previous generation of models. Let us consider next the modifications which should be made in creating the next generation of models.

\section{Exports}

The most important change is to provide for satisfactory treatment of exports. The obvious step is to include export functions of the form

$$
e_{h}=f\left(y_{t}, \frac{p_{t h}^{w}}{p_{h}^{d}}, \varepsilon_{t}\right) \quad \begin{aligned}
& i \in I \\
& t \in T
\end{aligned}
$$

where

$$
\begin{aligned}
& \varepsilon_{n}=\text { exports of commodity } i \text { in period } t \\
& y_{t}=\text { world income } \\
& p_{n}^{n}=\text { world price of commodity } i \text { in period } t \\
& p_{h}^{d}=\text { domestic price of commodity i in period } t \\
& \varepsilon_{t}=\text { exchange rate }
\end{aligned}
$$

If the function is to be included in a general nonlinear model like the Kendrick and Taylor model, it can be used in its estimated 


\section{ECONOAY-WIDE MODELS}

nonlinear form. If it is to be used in a linear model like the Marten and Pindyck model, then it must be linearized.

If a quadratic-linear tracking model is used, then the model might not only include a linearized version of Eq. (26) but also could include desired paths for sectoral exports. The desired paths could reflect expectations for different growth rates of exports from the various sectors as well as export promotion plans by the government and by private firms.

The use of Eq. (26) requires domestic prices. This in turn raeans that the model should include price and wage equations which can be used not only for foreign trade analysis but also for income distribution.

\section{Wages and Prices}

Some economists would prefer growth models which contain three sets of prices: (i) current, (ii) shadow, and (iii) world. The notion is that current prices are sometimes distorted, while world prices are not always the socially optimal prices for a country. Therefore the idea is to obtain shadow prices by solving growth models in which the objective function is the discounted value of output valued in world prices. The shadow prices from these solutions would then be used in sectoral models to determine dynamic comparative advantage. This procedure holds some promise for a key price in the economy: namely the price of foreign exchange. This is so because even an aggregated model will have a balance of payments constraint and this will yield a shadow price for foreign exchange. However, most growth models are not disaggregated enough to include all the price of commodities which are required to make a careful evaluation of dynamic comparative advantage at the level of the sectoral models. Also, this approach can require the use of models which are linear in investment activities and which therefore exhibit behavior in which investment bangs back and forth between upper and lower bounds.

Shadow prices aside, there are two alternatives for wage and price equations. One method would be to include a general equilibrium model within the growth model. Thus in each time period a static general equilibrium model would be solved to determine all factor and commodity prices. While this approach is feasible it has the shortcoming that distributed lag relationships and therefore timing would not be included. 
A second method would be to use price and wage equations like those developed for econometric models. These equations almost always include distributed lag relationships. Also, they can be specified to capture input-output information as well as the effects of changes in world prices and exchange rates.

\section{Iacome Distribution}

Once wage and price equations are added to growth models, it is possible to use the models to analyze the effects of various policies on income distribution. Two approaches paralleling those described above for wages and prices can be considered. If a static general equilibrium model is embedded in the growth model then income distribution can be included in just the manner described in some detail in the previous chapter. This of course would necessitate using the general equilibrium methods for wages and prices as well.

The econometric model approach to income distribution has traditionally been to include factor payments but not to incorporate specifications which would permit any analysis of the size distribution of income. Of course the general equilibrium models also do not focus on the size distribution of income but rather on the distribution of income between various types of households like rural and urban households. However, there is no reason why household type income distribution equations cannot be specified and estimated for econometric model-type equations. Neither is there any reason why these equations cannot be incorporated into growth models.

The crucial difficulty may be the availability of time series information on income distribution. Social accounting matrices and general equilibrium models have traditionally been constructed from data on a single year's income distribution data. In contrast, econometric modeling would require a time series of income distribution information.

An alternative approach to income distribution is to add constraints for basic needs to the growth models. Some economists favor this approach as a way to represent at least a portion of the income distribution in the model and a way to cover the needs of the most impoverished part of the society. 


\section{Economies of Scalc}

Some inclusion of economies of scale in growth models has been done recently in work by Kennedy and Rostow (1988) which is similar to the discussion of increasing returns to scale in growth models in Solow's work (discussed in Chapter 22 of Branson (1979)).

Altematively, multiperiod linear economywide models with economies of scale can be developed and solved using linear mixed integer programming methods in the tradition of Westphal (1971). Westphal's method is to develop a linear multisectoral dynamic model in the tradition of Eckaus and Parikh (1968) and of Bruno (1966) and then to add to it sectoral models for one or two sectors. The sectoral models are like those discussed in Chapter 2 of this monograph. This approach has the disadvantage that it requires linearity and that it is computationally expensive; however it is the only proven method for including economies of scale in multiple sectors in a dynamic model.

\section{Technical Change}

One of the most important elements in economic growth is technical change. Yet growth models typically treat technical change as exogenous. The exception is some work in the growth theory field which used capital and labor prices to analyze a tendency for rechnical change to be either capital saving or labor saving. However, this was a limited effort and did not really tackle the larger problem of predicting bursts of technical change which economic bistorians can document but which model builder have had difficulty incorporating.

There is renewed effort in this direction in the current research of Kennedy and Rostow (1988). Perhaps this project will provide new directions for the endogenous inclusion of technical change in dynamic multisectoral growth models.

There is an aspect of technical change which has perhaps received less attention than it deserves. A country's comparative advantage may be eroded over time by rapid technical change in 
another country. For example a country may be a strong exporter of steel products at one point in time, but then neglect technical progress while its competitors are making rapid gains. In this case, the country will awake from its slumber to find that it has lost it comparative advantage in that industry. One implication of this is that comparative advantage models should include decreasing world prices for commodities where there is rapid technical change.

\section{Conclusions}

The previous generation of growth models provides a solid foundation for continued progress by including capital accumulation, balance of payments, endogenous imports, sectoral investment, income elasticities of demand, and factor substitution. However, the shortcomings of these models leave much work to be done.

A new generation of models could be developed which add endogenous exports, prices and wages, income distribution, economies of scale, and perhaps technical change to growth modt els. The computational capability is available and the need for such specifications is apparent, so it seems likely that a new surge of activity in this field will produce major improvements in this class of models. 


\section{Appendix 5A Growth Models}

This appendix contains the GAMS statement of a reduced version of the Kendrick and Taylor model. The original model was solved for a thirty period time horizon while the current model is solved for a five period horizon. This GAMS version of the Kendrick and Taylor model is still being debugged so the interested reader may want to write the author for the current version.

$*$

- A DYNAMIC MULTISECTORAL NONLINEAR PLANNING MODEL

- REFERENCE: KENDRICK, DAVID A. AND LANCE J. TAYLOR

- (1969), "A DYNAMIC NONLINEAR PLANNING MODEL FOR

- KOREA", CH. 8 IN ADELMAN.M, PRACTICAL APPROACHES TO

- DEVELOPMENT PLANNING, THE JOHNS HOPKINS

- UNIVERSTTY PRESS, BALTIMORE.

- AND

- KENDRICK DAVID A. AND LANCE J. TAYIOR (1970),

- "NUMERICAL SOLUTION OF NONLINEAR PLANNING MODELS",

- ECONOMETRICA, VOL 38, NO. 3, MAY, PP. 453-467.

- THE GAMS VERSION WAS CREATED BY DAVID KENDRICK AND

- ANANTHA DURAIAPPAH, JULY 1988

SETS

J SECTORS

/ AGRI-MIN

HEAVYIND

LGHTIND

AGRICUITURE AND MINING

SERVICES

HEAVY INDUSTRY

$\operatorname{ALIAS}(\mathrm{J}, \mathrm{I})$;

SERVICES /

SETS

$T$ TIME PERIODS / $1 * 5 /$

TB(T) BASE PERIOD

TT(T) TERMINAL PERIOD;

$\mathrm{TB}(\mathrm{T})=$ YES $\$(O R D(T)$ EQ 1$)$;

$T T(T)=Y E S \$(O R D(T)$ EQ CARD $(T))$;

DISPLAY TB,TT; 
APP. 5A GROWTH MODELS 145

- parameters

SCALAR Z DISCOUNT RATE 10.03/;

PARAMETER DIS(T) DISCOUNT FACTOR; $\operatorname{DIS}(T)=(1+Z) *(-O R D(T))$

DISPLAY DIS;

PARAMETER ALPHA(J) COEFFICIENT IN WELFARE FUNCTION

$\begin{array}{ll}/ \text { AGRI-MIN } & .48 \\ \text { HEAVYIND } & .33 \\ \text { LIGHTIND } & .345 \\ \text { SERVICES } & .3925 /\end{array}$

PARAMETER PHI(J) EXPONENTS IN THE WELFARE FUNCTION

$\begin{array}{ll}\text { / AGRI-MIN } & .85 \\ \text { HEAVTIND } & .90 \\ \text { LIGHTIND } & .91 \\ \text { SERVICES } & .87 /\end{array}$

TABLE $A(I, J)$ INPUT-OUTPUT COEFFICIENTS

$\begin{array}{lcccc} & \text { AGRI-MIN } & \text { HEAVYIND } & \text { LIGHTIND } & \text { SERVICES } \\ \text { AGRIMMN } & .10 & .09 & .17 & .01 \\ \text { HEAVYIND } & .09 & .33 & .24 & .12 \\ \text { LGHTIND } & .04 & .02 & .12 & .05 \\ \text { SERVICES } & .03 & .09 & .09 & .08\end{array}$

TABLE B(I, CAPTAL COEFFICIENTS

AGRI-MIN HEAVYIND LIGHTIND SERVICES

$\begin{array}{lcccc}\text { HEAVYTND } & .6908 & 1.3109 & .1769 & .1500 \\ \text { LJGHTIND } & .0010 & .0199 & .0022 & .0000\end{array}$

TABLE PRODF(I,*) PRODUCTION FUNCTION PARAMETERS

ELASTICITY DISTRIBUT TECHNICALP EFFICIENCY INILAB $\begin{array}{llll}\text { AGRI-MIN } & 1.20 & .35 & .03\end{array}$

$\begin{array}{llllll}\text { LIGHTIND } & .90 & .25 & .025 & 1.26 & 0.84 \\ & .60 & .20 & .025 & & .47\end{array}$

$\begin{array}{llllll}\text { SERVICES } & .60 & .20 & .025 & .47 & 2.30\end{array}$ 


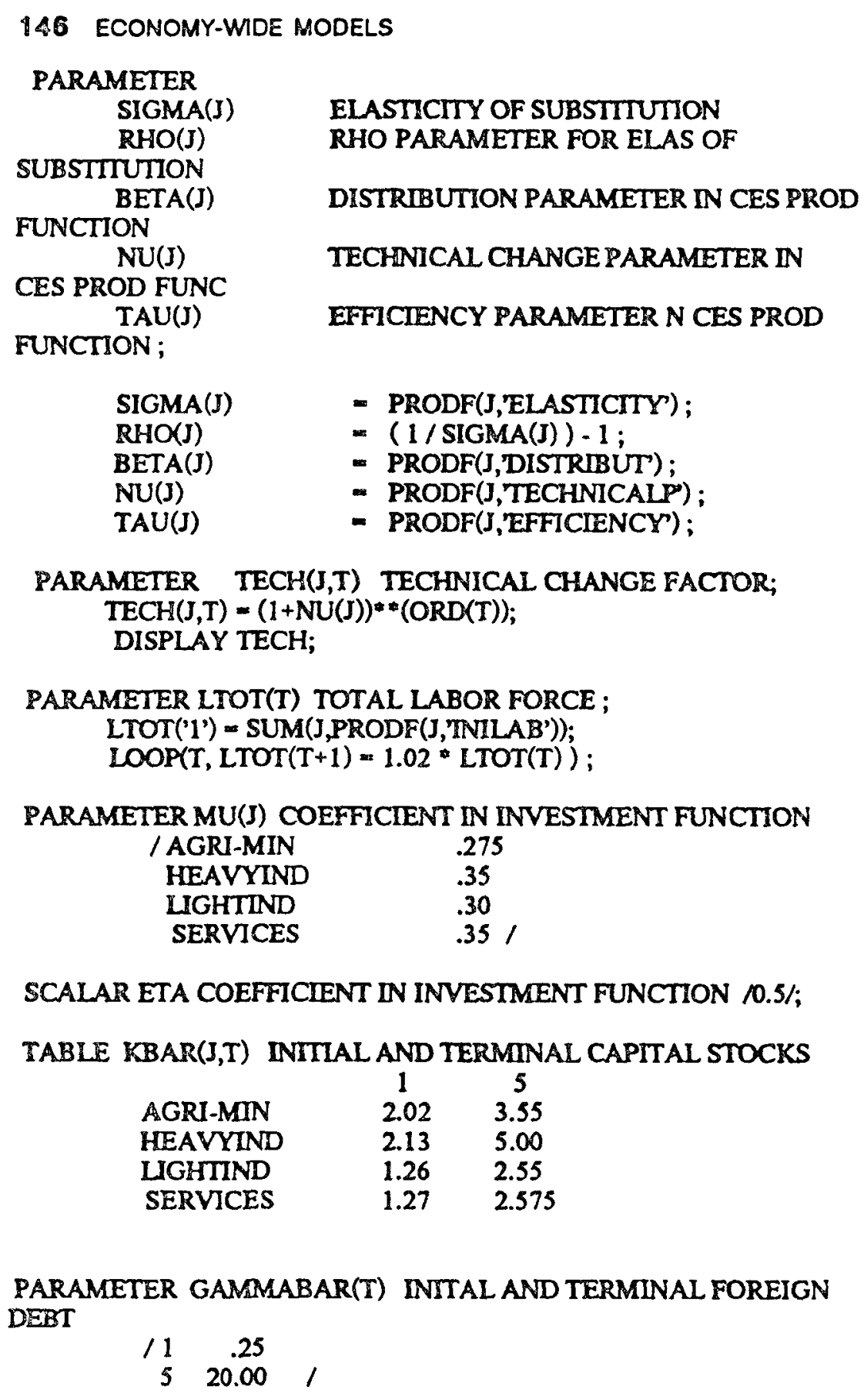


PARAMETER EXPTOT(T) TOTAL EXPORTS;

EXPTOT(' 1 ') = 3.4;

LOOP(T, EXPTOT $(T+1)=1.08$ * EXPTOT(T)) ;

DISPLAY EXPTOT;

TABLE EXPPER(J,T) SECTORAL EXPORT PERCENTAGES

$\begin{array}{lccccc} & 1 & 2 & 3 & 4 & 5 \\ \text { AGRI-MIN } & 0.20 & 0.20 & 0.20 & 0.20 & 0.20 \\ \text { HEAVYIND } & 0.10 & 0.10 & 0.10 & 0.10 & 0.10 \\ \text { LIGHTIND } & 0.30 & 0.30 & 0.30 & 0.30 & 0.30 \\ \text { SERVICES } & 0.40 & 0.40 & 0.40 & 0.40 & 0.40\end{array}$

PARAMETER E(J,T) SECTORAL EXPORTS;

$\mathrm{E}(\mathrm{J}, \mathrm{T})=\operatorname{EXPPER}(\mathrm{J}, \mathrm{T}) * \operatorname{EXPTOT}(\mathrm{T}) ;$

DISPLAY E;

SCALAR THETA INTEREST RATE ON FOREIGN DEBT /.05/;

PARAMETERS D(JJ) PROPENSTTY TO MMPORT FOR PROD

$\begin{array}{ll}\text { / AGRI-MIN.AGRI-MIN } & .0008 \\ \text { HEAVYIND.HEAVYIND } & .0900 \\ \text { LIGHTIND.LIGHTIND } & .0300 \\ \text { SERVICES.SERVICES } & .0040\end{array}$

PARAMETERS PI(J) PROPENSTTY TO IMPORT FOR INVEST

$\begin{array}{ll}\text { / AGRI-MIN } & .63 \\ \text { HEAVYIND } & .98 \\ \text { LIGHTIND } & .10 \\ \text { SERVICES } & .10\end{array}$

PARAMETER IDEN(1,J) IOENTITY MATRIX

/ AGRI-MIN.AGRI-MIN

HEAVYIND. HEAVYIND

LGHTIND.LIGHTIND

SERVICES.SERVICES

PARAMETER P(I,J) PRODUCTION COEF IN BALANCE EQ ; $P(I, J)=\mathbb{D E N}(I, J)-A(I, J)+D(I, J)$; DISPLAY P; 
148 ECONOMY-WMDE MODELS

$\begin{array}{ll}\text { VARIABLES } & \\ \text { C(J,T) } & \text { CONSUMPTION } \\ \text { DELTA(J,T) } & \text { INVESTMENT } \\ \text { G(J,T) } & \text { CAPACTYY ADDITIONS } \\ \text { GAMMA(T) } & \text { FOREIGN DEBT } \\ \text { K(J,T) } & \text { CAPITAL STOCKS } \\ \text { LJ,T) } & \text { LABOR } \\ M(J, T) & \text { IMPORTS } \\ \text { QJ,T) } & \text { PRODUCTION } \\ X I & \text { CRIERION VALUE }\end{array}$

EQUATIONS

CRITERION

CAPITALAC(J,T)

DEBTALAC(T)

INITCAP(J)

INITDEBT

TERMCAP(J)

TERMDEBT

CONSUMP(J,T)

LABOR(T)

PRODUCIION(J,T)

CADDI (J,T)

FIXIMPA(T)

FIXIMPS(T)

CRITERION FUNCTION
CAPITAL ACCUMULATION
FOREIGN DEBT ACCUM
INITIAL CAPITAL STOCKS
INITAL FOREIGN DEBT
TERMINAL CAPITAL STOCKS
TERMINAL FOREIGN DEBT
CONSUMPTION
LABOR
PRODUCTION FUNCTIONS
CAPACITY ADDIIION
FIX AGRI-MIN IMPORTS
FIX SERVICES IMPORTS;

CRITERION.. $\quad X I=E=\operatorname{SUM}(T, \operatorname{DIS}(T-1)$

- SUM(J,ALPHA(J)*C(J,T-1)**(PHI(J))));

CAPITALAC $(J, T+1) . . \quad K(J, T+1)=E=K(J, T)+G(J, T)$;

DEBTALAC $(T+1) . . \quad$ GAMMA(T+1) $=\mathrm{E}=(1+$ THETA $) * \mathrm{GAMMA}(\mathrm{T})$

$+\operatorname{SUM}(J, D(J, J) * Q(J, T)-E(J, T)$

$+\operatorname{PI}(\mathrm{J})=\operatorname{DELTA}(\mathrm{J}, \mathrm{T})+M(\mathrm{~J}, \mathrm{~T}))$;

INTCAP(J).. $\quad K\left(J, l^{\prime}\right)=E=\operatorname{KBAR}\left(J^{\prime}, \mathrm{I}^{\prime}\right)$;

INITDEBT..

GAMMA('1') $=$ L= GAMMABAR('1') ;

TERMCAP(J).

$K\left(J, S^{\prime}\right)=E=K B A R\left(J, 5^{\prime}\right)$;

TERMDEBT..

$\operatorname{GAMMA}\left({ }^{\prime} 5^{\prime}\right)=\mathrm{L}=$ GAMMABAR(' $\left.{ }^{\prime}\right)$; 
APP. 5A GROWTH MODELS 149

CONSUMP(I,T-1).. $\quad C(I, T-1)=E=\operatorname{SUM}(J, P(I, J) * Q(J, T-1))$

- SUM(J, B(IJ) * DELTA (J,T-1))

$-E(I, T-1)+M(I, T-1)$;

LABOR(T-1).. $\quad \operatorname{LTOT}(T-1)=E=\operatorname{SUM}(J, L(J, T-1))$;

PRODUCTION(J,T-1).. Q Q(J,T-1) $=E=\operatorname{TAU}(\mathrm{J}) * \operatorname{TECH}(\mathrm{J}, \mathrm{T}-1)$ *

$(\operatorname{BETA}(\mathrm{J}) * \mathrm{~K}(\mathrm{~J}, \mathrm{~T}-1) *(-\mathrm{RHO}(\mathrm{J}))$

$+(1-\operatorname{BETA}(\mathrm{J})) * \mathrm{~L}(\mathrm{~J}, \mathrm{~T}-1) *(-\mathrm{RHO}(\mathrm{J})))$

**(-1 / RHO(J));

CADDI(J,T-1).. $\quad \mathrm{G}(\mathrm{J}, \mathrm{T}-1)-\mathrm{E}=\mathrm{MU}(\mathrm{J}) * \mathrm{~K}(\mathrm{~J}, \mathrm{~T}-1)$ *

$(1-(1+(\operatorname{ETA} * \operatorname{DELTA}(J, \mathrm{~T}-1))$

$/(M U(J) * K(J, T-1))) *(-1 / E T A))$;

FIXIMPA(T-1).. $\quad$ M('AGRI-MIN,T-1) $=E=0$;

FTXIMPS(T-1).. M('SERVICES', $\mathrm{T}-1)=\mathrm{E}=0$;

\section{- LOWER BOUNDS ON VARIABLES}

$\begin{array}{ll}\text { K.LO(J,T) } & =0.001 ; \\ \text { LLO(J,T-1) } & =0.01 ; \\ \text { DELTA.LO(J,T-1) } & =0.001 ; \\ \text { G.LO(J,T-1) } & =0.001 ; \\ \text { C.LO(J,T-1) } & =0.01 ; \\ \text { Q.LO(J,T-1) } & =0.01 ; \\ \text { GAMMA.LO(T) } & =0.00 ; \\ \text { M.LO('HEAVYIND',T-1) } & =0.001 ; \\ \text { M.LO('LIGHTIND',T-1) } & =0.001 ;\end{array}$


150 ECONOMY-WDDE MODELS

- COMPILER SETTINGS

$\begin{array}{ll}\text { OPTION INTEGER3 } & =2 ; \\ \text { OPTION REALI } & =0.2 ; \\ \text { OPTION REAL3 } & =0.01 ; \\ \text { OPTION INTEGER4 } & =180 ; \\ \text { OPTION BRATIO } & =0 ; \\ \text { OPTION LMMROW } & =0 ; \\ \text { OPTION LIMCOL } & =0 ; \\ \text { OPTION INTEGER5 } & =0 ; \\ \text { OPTION ITERIIM } & =3000 ;\end{array}$

- MODEL STATEMENT

MODEL KENTAY/ALU;

- NOMINAL PATHS

C.L('AGRI-MTN','') $=0.124$

C.L('AGRI-MIN', '2') $=0.089$;

C.L'AGRI-MIN','3') = 0.142;

C.L('AGRI-MIN', '4') $=0.231$;

C.L('HEAVYIND', '1')=1.607;

C.L('HEAVYIND', '2') = 0.344;

C.L('HEAVYIND', '3') = 0.366;

C. L('HEAVYIND','4') = 0.411;

C.L'LIGHTIND','1') = 1.507 ;

C.L('LIGHTIND', $\left.2^{\prime}\right)=0.833$;

C.L'LIGHTIND', '3') $=0.799$

C.L'LIGHTIND', 4') = 0.638 ;

C.L('SERVICES', 'l') $=0.349$

C.L'SERVICES', '2') =0.297;

C.L'SERVICES','3') $=0.328$;

C.L'SERVICES', 4') $=0.368$;

DELTA.L'AGRI-MIN','1') $=0.001$;

DELTA.L'AGRI-MIN','2') $=0.623$

DELTA.L'AGRI-MIN', $3^{\prime}$ ') $=0.664$

DELTA.L'AGRI-MIN', '4') = 0.705 ; 
DELTA.L('HEAVYIND',' 1 ') $=0.001$

DELTA.L('HEAVYIND','2') $=1.308$; DELTA.L('HEAVYIND','3') $=1.493$ DELTA.L('HEAVYIND', '4') $=1.704$;

DELTA.L('LIGHTIND', ' 1 ') $=0.001$; DELTA.L('LIGHTIND',2') $=0.570$ DELTA.L('LIGHTIND', '3') $=0.633$; DELTA.L('LIGHTIND', '4') $=0.705$;

DELTA.L('SERVICES','l') $=0.001$; DELTA.L('SERVICES', '2') $=0.630$; DELTA.L'SERVICES', '3') $=0.625$ DELTA.L'SERVICES','4') =0.595;

K.L('AGRI-MIN',1') = 2.020; K.L('AGRI-MIN',') = 2.347;

K.L('AGRI-MIN', '3') = 2.711; K.L('AGRI-MIN','4') = 3.113; K.L('AGRI-MIN', '') = 3.550;

K.L('HEAVYIND','1') = 2.130 ; KLL'HEAVYIND',2') $=2.664$ K.L('HEAVYIND', '3') = 3.309; K.L('HEAVYIND', '4') = 4.083; KL('HEAVYIND', $5^{\prime}$ ) = 5.000;

KL('LIGHIIND', $\left.1^{\prime}\right)=1.260$; KL('LIGHTIND',2') - 1.515; K.L('LGHTIND' '3') $=1.812$; K.L('LGHTIND', '4') = 2.155; K.L('LIGHTIND',5') = 2.550;

K.L('SERVICES', 'I') = 1.270; K.L('SERVICES', '2') = 1.562; KL('SERVICES' ' $\left.3^{\prime}\right)=1.888$ K.L('SERVICES',') $=2.234$; K.L('SERVICES', $\left.5^{\prime}\right)=2.575$;

LLL(AGRI-MIN',' '') = 2.815;

LL('AGRI-MIN', '2') = 2.428;

LLL('AGRI-MIN','3') = 2.453;

L.L('AGRI-MIN','4') = 2.512; 
152 ECONOMY-WIDE MODELS

L.L('HEAVYIND','l') = 2.636;

LL('HEAVYIND' ' 2 ') = 3.907;

LL('HEAVYIND','3') = 4.068;

LL('HEAVYIND','4') = 4.244;

LL('LIGHTIND','1') = 0.938;

LU('LIGHIIND','2') $=0.475$;

LL('LIGHTIND','3') = 0.453;

LL('LIGHIIND',4') $=0.381$;

L.L('SERVICES',') $=2.211$;

L.L('SERVICES','2') = 2.048;

L.L('SERVICES','3') = 2.149;

L.L('SERVICES',4') - 2.260;

M.L $(J, T-1)=0.0$;

$G . L(J, T-1)=\operatorname{MU}(J) * \mathbb{K} . L(J, T-1) *(1-(1+(E T A * D E L T A . L(J, T-1)) /$

$(\mathrm{MU}(J) * \mathrm{~K} . \mathrm{L}(\mathrm{J}, \mathrm{T}-1))) * *(-1 / \mathrm{ETA}))$;

- SOLVE STATMENT

SOLVE KENTAY USING NLP MAXTMIZING XI; 
Part III

Conclusions 


\section{Conclusions}

What then is the comparative advantage of each of the different classes of models for analyzing dynamic comparative advantage? This will be discussed shortly but first an overarching issue will be addressed.

In recent years there has been a resurgence of support for the efficacy of free markets and a tendency to turn away from central planning. This view has gained strength in the United States and in Europe and has swept across Latin America and Asia. One part of this resurgence of the market has been a push toward free trade, away from import substitution, and toward export led growth. According to this view, the best way of determining dynamic comparative advantage is to leave everything to the market. Private entrepreneurs are seen as nimble people who will embrace rapid technical change and avoid the ponderous pace of state-run enterprises. Government controls on international trade are seen as creating rent seeking activities which sap the economic strength of national economies.

There is much to this point of view. In a rapidly changing world a decentralized market economy may be able to respond more quickly to change than can traditional state enterprises. Also, market economies tend to decentralize incentives and thus enhance productivity. If this is so then what is the role for mathematical models which have in the past been associated with central planning? The answer is: a large role. The models do not belong to either of the ideological positions of free markets or central planning. In fact the greatest use of sectoral models is not by governments in centrally planned economies but by private enterprises in decentralized economies. Indeed, private companies which eschew the use of computer models of their industries may be placing themselves at a decided disadvantage in the competitive battles between firms.

Also, governments - no matter their ideological position - will continue to be concerned with income distribution. Thus the sectoral models will be complemented by computable general equilibrium models which make it possible to analyze the 
commodity and factor price effects of policies and thus to focus on the income distribution results of policies.

If models like these are to be used in both centralized and do centralized economies, what is the comparative advantage of the different classes of models discussed in this book?

First the sectoral models. These models have been and will be used to analyze single industries and groups of industries within single countries, combinations of countries, and in the entire world. They are useful in determining the optimal choice of technology as well as the size of production facilities. They aid in decisions on which products to produce and the inputs to use. They are of great help in deciding where to locate facilities and where to ship products. They are useful in determining which goods should be imported, which produced domestically, and which exported. The models permit the analysis of economies of scale in a dynamic setting. While this has normally been done for intemal economies of scale, multi-industry models will also permit the analysis to be extended to external economies of scale.

Sectoral models can be used both in situations where perfect competition assumptions hold and in situations where these assumptions are violated. Under perfect competition, for cxample, the models specify that unlimited amounts of imports can be bought at the world market price and unlimited quantities for exports can be supplied at the world market price. In the absence of perfect competition the sectoral models can be used to include the plants of a number of large firms and to elaborate scenarios in which first one firm and then another expands and cuts into the market share of the other. Moreover, these games can be analyzed not only in a dynamic but also in a spatial setting where market shares differ from city to city.

However, there is still substantial room for improvement in sectoral models. Most existing models are cost minimizing models with fixed demand, rather than profit maximizing models with price responsive demand. Uncertainty in demand and in cost factors is not included in a systematic way in the models. Inventories and inventory costs have not been treated adequately. Computational speeds still place important limits on the number of products, time periods, plants and markets which can be included in the models.

In summary, sectoral models still have some shortcomings but they are nonetheless powerful tools for analyzing the dynamic comparative advantage of a single industry or a group of industries. However, sectoral models are not broad enough in scope to 
include income distribution. For this one must tum to comprable general equilibrium models. These models permit endogenous calculations of both commodity and factor prices. Thus it is possible to study not only the effects of factor price changes on the income distribution but also the effect of commodity price changes on the welfare of different groups in the society.

With the creation of the HERCULES and GEMPACK modeling systems and advances in algorithms and codes for solving the models, there have recently been sharp gains as regards the effort required to develop and maintain general oquilibrium models and the size of the models which can be solved. This means that models can be constructed to analyze in a disaggregated setting the efficiency and equity effects of changes in tarifis and quotas as well as the effects of changes in export subsidies.

Computable general equilibrium models in turn have their shortcomings. Most important, they tend to be static models. Even when they are dynamic they are usually solved as a series of comparative static models which do not permit careful analysis of the timing of policy effects. Such timing rather requires growth models which can incorporate distributed lag structures.

Growth models provide a basis for a broad overview of trade policy in the context of the growth and development of a country. These models can incorporate income elasticities of demand in both domestic and foreign markets to provide guidance about which industries should grow rapidly and which should grow more slowly. They provide a useful framework for analyzing the saving-investment choice and for studying the sectoral allocation of investment. The models capture the balance of payments constraint well and permit study of import substitution or export led growth.

The larger issues of development policy are the traditional domain of growth theory. Some of these issues are: (1) consumption versus investment choices, (2) investment allocation to heavy versus light industries, (3) trade policy which favors import zubstitution versus export promotion, and (4) population policy which is permissive or restrictive. The growth models can provide a numerical foundation for these debates in a disaggregated setting. The saving-investment choice is still there, but growth models can be used to study the various sources of savings (i.e., corporate, individual, and government savings) and to analyze the role of pension funds and life-cycle savings on the aggreagate cavings behavior of the country. 


\section{CONCLUSIONS}

Investment allocation need not be discussed as simply heavy industry versus light industry but can be dealt with across a panoply of sectors with an eye to both domestic and foreign markets and keeping in mind both savings and foreign exchange constraints. Trade policy need not be debated as import substitution versus export promotion but rather may take into account subtleties in which the general strategy might be export promotion but with important exceptions for some infant industries where economies of scale are substantial. Also, the models make it possible to analyze the effects of tariffs and subsidies and the use of a given real exchange rate policy. Population policy can be analyzed by considering the effects both on the demand side, with increased demand for goods and services, and on the supply side with increased labor supply.

Growth models too, however, are in need of improvement. These models have in the past not included endogenous price determination. Also, they have sometimes made exports exogenous rather than endogenous and price responsive. Technical change is important to economic growth but it has not been included sdequately in existing models. Typically the growth models have not captured economies of scale. Also, these models are 80 broad in their scope that they cannot provide the kind of detail which is used in the sectoral models for a careful analysis of dynamic comparative advantage at the project level. Finally, growth models have largely ignored income distribution issues.

In summary, models for comparative advantage may be in a situation like economic growth in Europe and Japan in the 1950 s. At that time there was a large backlog of technical knowledge waiting to be incorporated into the economies of those countries. In recent years there has been major technical progress in model specification, in modeling systems like GAMS, HERCULES, and GEMPACK, in model solution algorithms, and in microcomputer and mainframe capabilities. Substantial opportunities are available for gaining a deeper insight into dynamic comparative advantage by exploiting the new technologies which have been developed in the last twenty years. 
Appendices 


\section{Appendix A \\ Latin American Models}

This appendi $x$ contains a listing of a selection of Latin American models of the types covered in this monograph. The sample draws heavily on the set of models which are contained in the GAMS library of models. No attempt has been made to be comprehensive rather only to provide some illustrations. Some of the models are not distributed with the GAMS library but were developed in the CAMS system. The annotation "in GAMS" is placed beside those those models.

Table A. 1 Single Country Sectoral Models

\begin{tabular}{|c|c|c|c|}
\hline Industry & Country & Study & $\begin{array}{l}\text { GAMS } \\
\text { Library } \\
\text { Name }\end{array}$ \\
\hline Petrochemicals & INexico & $\begin{array}{l}\text { Jimenez, Rudd, and } \\
\text { Meyer (1982) }\end{array}$ & \\
\hline eel & Brazi] & Kendrick (1967) & \\
\hline eel & Mexico & $\begin{array}{l}\text { Kendrick, Meeraus, } \\
\text { and Alatorre(1984) }\end{array}$ & MEXSD \\
\hline
\end{tabular}

Table A_2 Regional Sectoral Models

$\begin{array}{lll}\text { Industry } & \text { Study } & \begin{array}{l}\text { GAMS } \\ \text { Library } \\ \text { Namo }\end{array} \\ \text { Fertilizer } & \begin{array}{l}\text { Mennes and Stoutjesdijk } \\ (1985)\end{array} & \text { ANDEAN } \\ \text { Natural Gas } & \text { Manne and Beltramo (1984) } & \text { GTM } \\ \text { Fertilizer } & \text { Manne and Vietorisz (1963) } & \text { VIETMAN }\end{array}$


162 APPENDICES

Table A.3 Global Soctoral Modols

$\begin{array}{lll}\text { Industry } & \text { Study } & \begin{array}{l}\text { GAMS } \\ \text { Library } \\ \text { Name }\end{array} \\ \text { Aluminum } & \begin{array}{l}\text { Brown, Dammer, Meeraus, } \\ \text { and Stoutjesdijk(1983) }\end{array} & \text { ALUM } \\ \text { Copper } & \begin{array}{l}\text { Dammert and Palaniappan } \\ \text { (1985) }\end{array} & \text { COPPER } \\ \text { Petrochemicals } & \text { Manouchehri Adib (1985) } & \text { in GAMS } \\ \text { Petrochemicals } & \text { Sigurdsson and Rudd (1988) } & \\ \text { Petroleum } & \text { Langston(1983) } & \text { in GAMS }\end{array}$

Table A.4 General Equilibrium Models

\begin{tabular}{|c|c|}
\hline Country & Study \\
\hline
\end{tabular}

Brazil Taylor, Bacha, Cardoso, and Lysy (1980)

Table A.5 Growth Models

$\begin{array}{lll}\text { Country } & \text { Study } & \begin{array}{l}\text { GAMS } \\ \text { Library } \\ \text { Name }\end{array} \\ \text { Mexico } & \text { Manne (1973) } & \text { DINAMICO } \\ \text { Mexico } & \text { Alatorre (1981) } & \end{array}$




\section{References}

Anderson, A. and R. Turvey (1977), Electric Economics: Essays and Case Studies, Johns Hopkins University Press, Baltimore, Maryland.

Alatorre, Jaime (1981), A Long Term Planning Model for Mexico, Monograph, Center for Economic Research, The University of Texas, Austin, Texas.

Branson, William H. (1979), Macroeconomic Theory and Policy, 2ad edition, Harper and Row, Publishers, New York.

Brooke, Anthony, David A. Kendrick and Alexander Meeraus (1988), GAMS, A User's Guide, The Scientific Press, Redwood City, California.

Brown, Martin, Alfredo Dammer, Alexander Meeraus, and Ardy Stoutjesdijk (1983), World Investment Analysis: The Case of Aluminum, World Bank Staff Working Papers, Number 603, The World Bank, Washington, D.C.

Bruno, Michael (1966), "A Programming Model for Israel," Ch. 12, pp. 327-354 in I. Adelman and E. Thorbecke (eds), The Theory and Design of Economic Development, The Johns Hopkins University Press, Baltimore, Maryland.

Chakravarty, S. and L. Lefeber (1965), "An Optimizing Planning Model," Economic Weekly, Vol. 17, February, pp. 237 252.

Chames, A. W. and W. Cooper (1959), "Chance-Constrained Programming", Management Science, Vol. 6, No. 1, October, pp. 73-79.

Chenery, Hollis B. (1961) "Comparative Advantage and Development Policy", American Economic Review, Vol. 51, No. 1, March, reprinted in Hollis Chenery, Structural Change and Development Policy, Oxford University Press, New York. 
164 REFERENCES

Choksi, Armeane M., Alexander Meeraus, and Ardy J. Stoutjesdijk (1980), The Planning of Investment Programs in the Fertilizer Industry, Johns Hopkins University Press, Baltimore, Maryland.

Codsi, G. and K. R. Pearson (1988), "GEMPACK: GeneralPurpose Software for Applied General Equilibrium and Other Economic Modellers," Computer Science in Economics and Management, Vol. 1, No. 3, pp. 189208.

Colias, John V. (1985), A Sectoral Applied General Equilibrium Model of the United States Economy, Ph.D. dissertation, Department of Economics, The University of Texas, Austin, Texas.

Dammert, Alfredo and Sethu Palaniappan (1985), Modelling Investment in the Wordd Copper Sector, The University of Texas Press, Austin, Tezas.

Debreu, Gerard (1959), Theory of Value, John Wiley and Sons, Inc., New York.

Dervis, Kemal, Jaime de Melo, and Sherman Robinson (1982), General Equilibrium Models for Development Policy, Cambridge University Press, New York.

Dixon, Peter B. (1979), "A Skeletal Version of Orani 78: Theory, Data, Computations, and Results," Preliminary Working Paper No. OP-24, Impact Research Center, Industrial Assistance Commission, 608 St. Kilda Road, Melbourne, Victoria, 3004, Australia.

Dixon, Peter B., B. R. Parmenter, John Sutton, and D. P. Vincent (1982) ORANI: A Multisectoral Model of the Australian Economy, North Holland Publishing Company, Amsterdam.

Dixon, Peter B. and Alan A. Powell (1979), Structural Adaptation in an Ailing Macrocconomy, Melboume University Press, Melbourne. 
Drud, Ame (1989), "HERCULES, A Modeling System with Knowlodge about Economics," Computer Science in Economics and Management, Vol. 2, No. 1, pp 83-99.

Drud, Ame, Wafik Grais, and Graham Pyatt (1983), "The Transaction Value Approach: A Systematic Method for Defining Economywide Models Based on Social Accounting Matrices," in L. F. Pau (ed), Dynamic Modelling and Control of National Economies, Pergamon Press, New York.

Drud, Ame and David Kendrick (1987), HERCULES, A System for Large Economywide Models, Development Research Department, The World Bank, Weshington, D.C.

Eckaus, R. S. and K. S. Parikh (1968), Planning for Growth: Multisectoral Intertemporal Madels Applied to India, M.I.T. Press, Cambridge, Mass.

Gately, D. I. (1971), "Investment Planning for the Electric Power Industry: A Mixed-Integer Programming Approach, with Applications to Southern India," Ph.D. Dissertation, Princeton University, Princeton, New Jersey.

Jimenez, A., D. F. Rudd, and R. R. Meyer (1982), "A Study of the Development of the Mexican Petrochemical Industry Using Mixed-Integer Programming," Computers in Chemical Engineering.

Johansen, L. (1960), A Multi-Sectoral Model of Economic Growth, North Holland Publishing Company, Amsterdam (2nd Edition 1974).

Kendrick, David A. (1967), Programming Investment in the Process Industries, M.I.T. Press, Cambridge, Mass.

Kendrick, David A. (1981), Stochastic Control for Economic Models, McGraw Hill Book Company, New York.

Kendrick, David A. (1984), "Style in Multisectoral Modeling", Ch. 15 in A. J. Hughes Hallet (editor), Applied Decision 
185 REFERENCES

Analysis and Economic Behavior, Martinus Nijhoff Publishers, Dordrecht, The Netherlands.

Kendrick, David A., Alexander Meeraus, and Jaime Alatorre (1984), The Planning of Investment Programs in the Steel Industry, Johns Hopkins University Press, Baltimore, Maryland.

Kendrick, David A. and Ardy J. Stoutjesdijk (1978), The Planning of Investment Programs: A Methodology, Johns Hopkins University Press, Baltimore, Maryland.

Kendrick, David A. and Lance J. Taylor (1969), "A Dynamic Nonlinear Planning Model for Korea," Ch 8, pp. 213 237 in Irma Adelman (ed), Practical Appraaches to Development Planning, The Johns Hopkins University Press, Baltimore, Maryland.

Kendrick, David A. and Lance Taylor (1970), "Numerical Solution of Nonlinear Planning Models", Econometrica, Vol. 38, No. 3, May, pp. 453-467.

Kennedy, Michael and Walt Rostow (1989), Madels of Economic Growth", mathematical appendix in Walt Rostow, Theorist of Economic Growth from David Hume to the Present, Oxford University Press, London.

Kwun, Younghan (1986), "Joint Optimal Supply Planning of Industrial Cogeneration and Conventional Electricity Systems," Economic Research Division, Public Utility Commission of Texas, Austin, Texas.

Lengston, Vicky Corinne (1983), "An Investment Model for the U.S. Gulf Coast Refining/Petrochemical Complex", Center for Economic Rescarch, The University of Texas, Austin, Texas.

Manne, Alan S. (1973), "DINAMICO, A Muiti-Sector, MultiSkill, Model, in L. M. Goreux and A. S. Manne (eds), Multi-Level Planning: Case Studies in Mexico, North Holland Publishing Co., Amsterdam. 
Manne, Alan S. and M. S. Beltramo (1984), "An International Gas Trade Model", International Energy Program Report, Stanford University, Stanford, California.

Manne, Alan S. and T. E. Weisskopf (1972) "A Dynamic MultiSectoral Model for India:1967-1975," in A. Carter and A. Brody (eds) Applications of Input-Output Analysis, North-Holland Publishing Company, Amsterdam.

Manne, Alan S. and T. Vietorisz (1963), "Chemical Processes, Plant Location, and Economies of Scale", in A. Manne and H. Markowitz (eds), Studies in Process Analysis, John Wiley and Sons, New York and London.

Manouchehri Adib, Parviz (1985), An Investment Planning Model of the World Petrochemical Industry, Ph.D. dissertation, Department of Economics, The University of Texas, Austin, Texas.

Markowitz, H. M. and Alan S. Manne (1957), "On the Solution of Discrete Programming Problems," Econometrica, Vol. 25, January, pp. 84-110.

Martens, Andre and Robert Pindyck (1975), "An Optimal Control Model for Multisectoral Investment Planning in Tunisia," Joumal of Development Economics, Vol. 2, No. 2, pp 99.119.

Melton, J. W. (1982), An Investment Planning Model for an Oil Shale Industry in the Piceance Basin, Center for Economic Research, The University of Texas, Austin, Texas.

Mennes, L. and A. Stoutjesdijk (1985), Multicountry Investment Analysis, The Johns Hopkins University Press, Baltimore, Maryland.

Pyatt, Graham and Jeffery I. Round (1977), "Social Accounting Matrices for Development Planning", Review of Income and Wealth, Series 23, No. 4, pp. 339-64. 
168 REFERENCES

Pyatt, Graham and Jeffrey 1. Round (eds) (1985), Social Accounting Matrices, a Basis for Planning, World Bank Symposium Series, Washington, D.C.

Sigurdsson, S. and D. F. Rudd (1988), "Trends in the Intemational Production and Trade in Petrochemicals," Chem. Engr. Comm., in press.

Stone, J. R. N. (1961), Input-Output and National Accounts, OECD, Paris.

Suh, J. S. (1981), An Investment Planning Model for the Oil Refining and Petrochemical Industies in Korea, Center for Economic Research, The University of Texas, Austin, Texas.

Taylor, Lance J. (1979), Macro Models for Developing Countries, McGraw-Hill Book Company, New York.

Taylor, Lance J., Edmar L. Bacha, Eliana A. Cardoso, and Frank J. Lysy (1980) Models of Growth and Distribution for Brazil, Oxford University Press, New York.

Wei, Gwei-nyu Diana (1984), A Linear Process Model for the Steel Industries in the United States, the European Community, and Japan, Master Thesis, Department of Economics, The University of Texas, Austin, Texas.

Westphal, Larry W. (1971), "An Intertemporal Planning Model Featuring Economies of Scale," in H. B. Chenery (ed), Studies in Development Planning, Harvard University Press, Cambridge, Mass.

World Bank (1982), "Yemen Arab Republic - Manufacturing Industry: Performance, Policies and Prospects", Report Number 3651-YAR, Appendix II, Washington, D.C. 


\section{Index}

absorptive capacity function

122

account table 88

Adelman, Ima 166

Alatorre, Jaime 19, 33, 37 , $44,53,126,161,162,163$, 166

aluminum 60,162

aluminum industry 56

Andean Common Market 53

Anderson, A. 53, 163

Australia 67,77

automobile industry 11

Bacha, Edmar L. 66, 162,

168

balance of trade 83

balanced growth 119

Beltramo, M. S. 55, 161,

167

binary variable 39

Branson, William H. 142, 163

Brazil 161, 162

Brody, A. 167

Brooke, Anthony v, 26, 52 , 112,163

Brown, Martin 56, 60, 162, 163

Bruno, Michael 120, 142 , 163

capacity 11,21

capacity constraint 37

capital cost 40

Cardoso, Eliana A. 66, 162, 168

Carter, A. 167

cell table 90

cement 44,53

central planning 155
CES 90,97

CGE 66

Chakravarty, S. 120, 163

chance constrained

programming 17

Charnes, A. W. 17, 163

Chenery, Hollis B. vi, 119,

163,168

China 51

choice of technology 46, 156

Choksi, Armeane M. 49, 53,

164

Cobb-Douglas 80, 90

Codsi, G. 86, 164

COLA 84

Colias, John V. 77, 164

commodities

composite 74,95

comparative advantage

approach 119

privately cvahuated 3

socially evaluated 3

comparative statics 91

composite commodities 95

computable general

equilibrium 66,157

computable general

equilibrium models 155

computational cost 48

computational speed 18

constant elasticity of

substitution 70, 120, 124

consumer price index 69,84 ,

111

consumer surplus 14

consurnption shares 121

control variable 133

control theory 119

stochastic 17 
170 INDEX

convex combination 37,40

Cooper, W. 17, 163

copper 60,162

cost of living adjustment 84

current account deficit 126

Dammert, Alfredo 56, 60,

$162,163,164$

de Melo, Jaime 66, 164

Debreu, Gerard 66, 164

decreasing cost 17

demand function 14,16

demand requirements 21

Dervis, Kemal 66, 164

desired path 132

development policy 119

development strategy 65

direct reduction 46

discount rate 121

diseconomies of scale 15,37

display statement 91

Dixon, Peter B. 2, 67, 77,

106, 164

Drud, Arse 2, 66, 88, 165

Eckaus, R. S. 120, 142, 165

ECLAC vi

Economic Commission for

Latin America and the

Caribbean vi

economies of scale 14,17,

$37,45,142$

extemal 156

internal 156

efficiency gains 66

Egypt 49

elasticities of substitution 75

electric power 44,53

endogenous price determina.

tion 158

exchange rate 75,86

export functions 139

export led growth 155

export promotion 119

export subsidies 65,86 external economies

dynamic 17

extraregional 52

factor prices 17

fertilizer $44,53,161$

fertilizer industry 49

final products 9

foreign debt accumulation

126

free markets 155

free trade 155

game theory 16

GAMS v, 26, 52, 74, 86, 106, 144, 158

Model Library v, 52 , 112,161

Garciá, Eduardo vi

gas trade model 55

Gately, D. I. 53, 165

GEMPACK 86, 157, 158

general.equilibrium 66

Goreux, L. M. 166

Grais, Wafik 66, 165

grid point variables 40

grid points 37

growth model approach 119

HERCULES 2, 66, 70, 74, $88,157,158$

Hughes Hallet, A. J. 165

ILPES vi

import duties 86

import substitution 65,66 ,

119,155

import tarifts 65

income distribution 65,66 , $86,90,141,155$

income elasticities 12

income elasticities of demand 157

India 51

infrastructure 59

input demand function 108

intermediate products 9 
interplant shipments 7, 36

intraregional 52

investment cost function 37

Jimenez, A. 53, 161, 165

Johansen, L. 66, 165

Kendrick, David A. v, 2, 3, $17,19,26,33,37,44,52$, $53,66,77,88,106,112$,

$119,121,144,161,163$, 165,166

Kennedy, Michael 142, 166

knowledge base 74

Xwun, Younghan 53, 166

Lengston, Vicky Corinne 60, 162,166

Latin America 161

Latin American and

Caribbean Institute for

Economic and Social

Planning vi

Lefeber, L. 120, 163

linear mixed integer pro-

gramming problem 16

linear programming models

119

linearized form 77

linearizing 66

list of accounts 88

Lysy, Frank J. 67, 162, 168

mainframe computer 18

Manne, Alan S. 15, 53, 55,

$120,161,162,166,167$

Mancuchehri Adib, Parviz

$60,162,167$

market clearing couations 78

Markowitz, H. M. 15, 167

Martens, Andre 119, 131,

134, 167

material balance constraints 11

materials balance 21,136

maximum export constraint 38
Meeraus, Alexander vi, 19 ,

$26,33,37,44,49,52,53$,

$56,60,112,161,162,163$,

164,166

Melton, J. W. 53, 167

Mennes, L. 53, 161, 167

Mexico 26, 161, 162

Meyer, R. R. 53, 161, 165

microcomputer 18

mixed integer programming 15

natural gas 55, 161

nonlinear mixed integer

programming problem 16

notation 35

numeriare 98

oil refinery 21

oil shale 53

opportunity cost 17

ORANI model $2,77,86$,

112

Organization for Economic

Cooperation and

Development 56

Palaniappan, Sethu 60, 162,

164

Parikh, K. S. $120,142,165$

Parmenter, B. R. 2, 67, 77,

106, 164

Pau, L. F. 165

Pearson, K. R. 86, 164

penalty weights 132

petrochemicals $44,53,60$,

161,162

petroleum 60, 162

piecewise function 24

piecewise segments 16

Pindyck, Robert S. 119,

$131,134,167$

pipeline system 55

Powell, Alan A. 67, 164

price deflator 69 
172 INDEX

price elasticities of demand 75

prices

current 140

relative 12

shadow 140

world 140

process industries 44

process levels 21

processes 11

altemative 12

producer surplus 14

production function

fixed-coefficient 80

production functions 108

production levels 21

productive units 10

Project Impact 77

pulp and paper 44

Pyatt, Graham vi, 66, 165,

167,168

quadratic tracking function

132

quadratic-linear tracking

criterion functions 131

quantity solution 91

refinery 22

rental payments 40

Robinson, Sherman 66, 164

rolling-plan 17

rollover planning 48

Rostow, Walt 142, 166

Round, Jeffery I. 66, 167, 168

Rudd, D. F. 53, 60, 161,

$162,165,168$

SAM 66, 67, 89

saving-investment choice

157

sectoral allocation of

investment 157

set of accounts 90

shadow prices 140

\section{SIGMA 97}

Sigurdsson, S. 60, 162, 168

social accounting matrices 66

Solow, Robert 142

South Korea 119, 131

specification table 89, 96

state variable 133

state enterprises 155

steel $44,53,60,161$

steel industry 26

Mexican 7, 44

stcel mill 10

Stone, J. R. N. 66, 168

Stoutjesdijk, Ardy J. 49, 53,

$56,60,161,162,163,164$,

166,167

subsidies 75

Suh, J. S. 53, 168

supply response equations

107

Sutton, John 2, 67, 77, 106,

164

synergistic effocts 119

tariffs $59,65,75$

Taylor, Lance J. 3, 66, 119,

$121,144,162,166,168$

technical change 142,155

terminal conditions 127

tied imports 126

transport cost 21

transportation cost 12

Tunisia 119

Turvey, R. 53, 163

unbalanced growth 119

uncertainty

lange event 16

small event 16

United Nations Development

Program vi

value share 90

variable

control 133

state 133 
INDEX 173

variable elasticity of

aubstitution 70

Vietorisz, T. 53, 161, 167

Vincent, D. P. 2, 67, 77,

106,164

Wei, Gwei-nyu Diana 60,

168

Weisskopf, T. E. 120, 167

Westphal, Lany W. 131,

142, 168

World Bank 44, 51, 168 